\title{
29698
}

\section{Reforming Fiscal} and Economic Management in Afghanistan

MICHAEL CARNAHAN, NICK MANNING, RICHARD BONTJER, STERHANE GUIMBERT, EDITORS
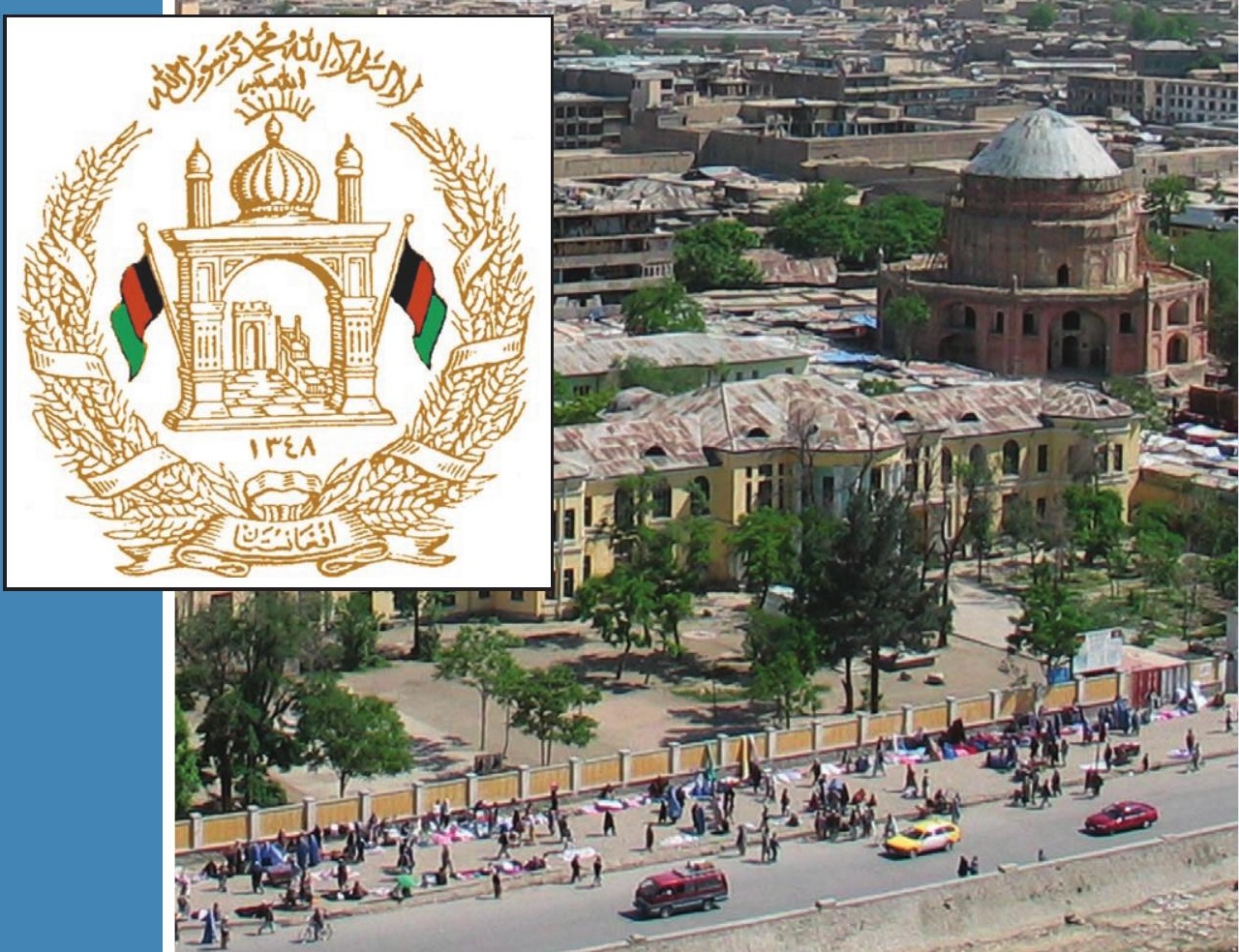

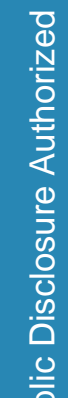

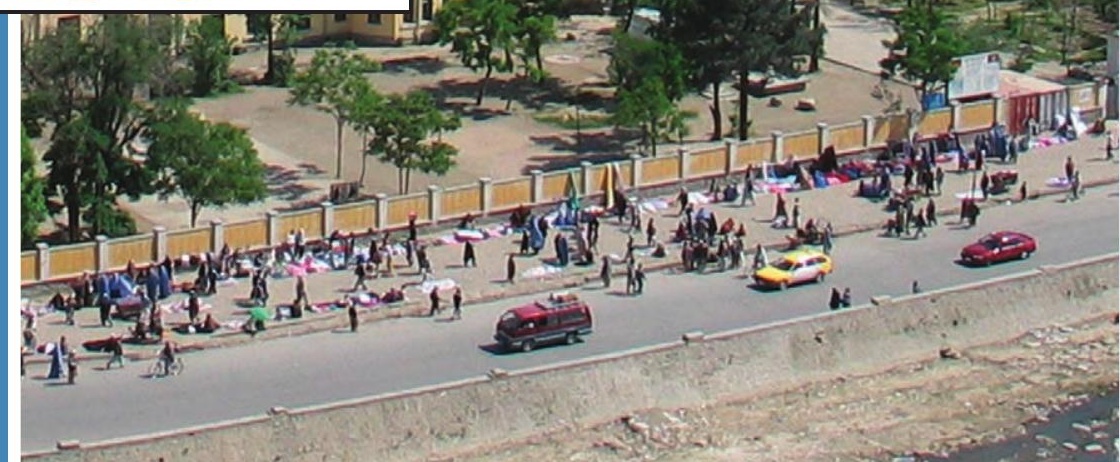





\section{Reforming Fiscal and Economic Management in Afghanistan}

Michael Carnahan, Nick Manning, Richard Bontjer, and Stéphane Guimbert

Editors

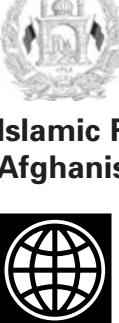

THE WORLD BANK

Washington, D.C. 
(C) 2004 The International Bank for Reconstruction and Development/THE WORLD BANK

1818 H Street, NW

Washington, DC 20433 USA

Telephone 202-473-1000

Internet www.worldbank.org

E-mail feedback@worldbank.org

All rights reserved

First printing

\section{4}

The findings, interpretations, and conclusions expressed here are those of the authors and do not necessarily reflect the views of the Board of Executive Directors of the World Bank or the governments they represent.

The World Bank does not guarantee the accuracy of the data included in this work. The boundaries, colors, denominations, and other information shown on any map in this work do not imply any judgment on the part of the World Bank concerning the legal status of any territory or the endorsement or acceptance of such boundaries.

\section{Rights and Permissions}

The material in this work is copyrighted. Copying and/or transmitting portions or all of this work without permission may be a violation of applicable law. The World Bank encourages dissemination of its work and will normally grant permission promptly.

For permission to photocopy or reprint any part of this work, please send a request with complete information to the Copyright Clearance Center, Inc., 222 Rosewood Drive, Danvers, MA 01923, USA; telephone 978-750-8400, fax 978-750-4470, www.copyright.com.

All other queries on rights and licenses, including subsidiary rights, should be addressed to the Office of the Publisher, World Bank, at the above address, by fax 202-522-2422, or e-mail pubrights@worldbank.org.

Cover design by Richard Fletcher of Fletcher Design.

\section{ISBN 0-8213-5786-7}

Library of Congress Cataloging-in-Publication Data has been applied for. 


\section{Contents}

Contributors vii

Acknowledgments viii

Acronyms $\quad$ ix

Glossary of Dari Terms $\quad$ xi

Dates and Currency xiii

Calendar xiii

Currency xiii

Preface xiv

Introduction $\quad$ xvii

PART I. THE JOURNEY SO FAR

1. Fiscal Management in Afghanistan-Major Achievements and Current challenges 3

Introduction 3

The Consequences of Conflict on Fiscal Management 4

Fiscal Management in Afghanistan $\quad 6$

Progress in Revenue $\quad 7$

Developments in the Ordinary Budget $\quad 12$

Financial Management System 20

$\begin{array}{ll}\text { Procurement } & 21\end{array}$

$\begin{array}{ll}\text { Audit } & 22\end{array}$

Development Budget $\quad 23$

Conclusion $\quad 29$

$\begin{array}{ll}\text { Notes } & 29\end{array}$ 
2. Executing the Budget Outside of Kabul 31

The Problem 31

Provincial Allotments for Non-Salary Expenditures

Are Generally Low

Non-Salary Expenditures Are Even Lower

Than the Allotments

Cash Flow Restrictions Exacerbate Execution Problems 38

Provincial Budget Allotments for

Salary Expenditures Can Be Low 39

Challenges in the Payroll Process $\quad 40$

Policy Implications $\quad 43$

Notes $\quad 47$

3. Case Studies in Post-Conflict Budgeting 48

Introduction 48

Post-Conflict Budgeting in East Timor $\quad 50$

Post-Conflict Budgeting in Eritrea $\quad 59$

Post-Conflict Budgeting in Uganda $\quad 62$

Notes 64

$\begin{array}{ll}\text { PART II. CURRENT PRIORITIES } & 65\end{array}$

4. Priorities for Reform in Post-Conflict Finance Ministries $\quad 67$

Introduction $\quad 67$

Desirable Functions for a Ministry of Finance 68

Political Accountabilities-One Minister or More? 72

Note $\quad 80$

5. Making the New Fiscal Constitution Work 81

A Presidential System for a Unitary State $\quad 81$

Implications of the 2004 Constitution $\quad 82$

The Role of the Parliament $\quad 89$

Conclusions and Recommendations $\quad 91$

Notes 92

6. Budget Law Reform 94

Introduction 94

The Objectives of a Budget System Law $\quad 94$

The Current Budget law 100

A New Budget System Law 101

Implementation of the New Budget System Law 106

Note 106 
7. Fiscal Management for the Provincial Municipalities

Summary

Municipalities within the Larger Public Sector

Municipal Institutional Structures

The Future Role of Municipalities in Implementation

A Strategy for Extending the Role of Afghanistan

Municipalities in Reconstruction

Notes

8. Next Steps in Reforming the Ministry of Finance

Introduction

Developing Consensus on the Core Business

From Theory to Practice

Tasks That the Ministry Should Not Undertake

Managing Transition

Notes

References

\section{Tables}

1. Traditional Process for Executing Non-Salary Payments

2. SY1381 Budget Execution, by Expenditure Category

3. Problems and Solutions in the Payroll Process

4. Functions and organizational responsibilities in the Ministry of Finance

5. Options for Political Accountability

6. Budget Amendment Powers of National Legislatures

7. Legal and Institutional Framework of Budget Systems

8. Structure of the Public Expenditure and Financial

Management Law for Afghanistan

9. Provincial Municipalities: Revenues and Expenditures for 1381, in afghanis

10. Provincial Municipalities: Staffing Structure for 1381

11. Employment Authorities for Staff

12. District Administrations by Province

13. Formal Central/Local Relationships in Afghanistan

14. Sources of, and Means of Reducing, Fiduciary Risk

\section{Figures}

1. Delays in Salary Payments for the Provinces (excluding police) 21

2. Execution of the Development Budget-SY1382

3. Distribution of SY1382 First-Quarter Allotments, 
4. The Budget Cycle 125

5. Planned Structure of the Ministry of Finance 134

6. Planned Revenue Structures (Headquarters) 136

7. Planned Revenue Structures (Provinces) 137

8. Planned Customs Department 138

9. Planned Treasury Department 139

10. Planned Budget Department 140

11. Planned Department for Administrative Services 141

\section{Boxes}

1. Passage of the 1381 Budget 14

2. The Politics of the Defense Budget 15

3. Developments in Payroll Processing and Salary Payments 22

4. Issues in Managing the Development Budget 24

5. The National Development Framework 26

6. Tashkeel versus Takhsis (Allotment) 40

7. Managing the Payroll in Remote Districts 42

8. New Allotment Procedures for 1383

9. Organizational Restructuring Needed in Kabul Municipality 118

10. Who Is Responsible for Civil Service Policy? 143 


\section{Contributors}

Ehtisham Ahmad: Division Chief, IMF

Richard Bontjer: Advisor, Ministry of Finance, Transitional Islamic State of Afghanistan

Nicholas Calcoen: Technical Assistance Advisor, IMF

Michael Carnahan: Advisor, Ministry of Finance, Transitional Islamic State of Afghanistan

Piyush Desai: Senior Economist, IMF

Bill Dorotinsky: Lead Public Sector Specialist, World Bank

Anne Evans: Consultant, World Bank

Ashraf Ghani: Minister of Finance, Transitional Islamic State of Afghanistan

Soraya Goga: Urban Specialist, World Bank

Stéphane Guimbert: Economist, World Bank

Malcolm Holmes: Consultant, World Bank

Thierry Kalfon: Economist, IMF

Peter Kohnert: Technical Assistance Advisor, IMF

Ian Mackintosh: Manager, World Bank

Nick Manning: Lead Public Sector Management Specialist, World Bank

Peter Middlebrook: Consultant, World Bank

Allister Moon: Lead Public Sector Management Specialist, World Bank, formerly Chief Economic Advisor to the Ugandan Ministry of Finance, Planning and Economic Development

Bernard Myers: Consultant, World Bank

Dimitar Radev: Technical Assistance Adviser, IMF

Eivind Tandberg: Deputy Division Chief, IMF

Linda van Gelder: Senior Economist, World Bank

Gebreselassie Yosief Tesfamichael: Finance Minister of Eritrea from 1997 to 1999, formerly Head of the Office of Management and Budget in the President's Office

Joachim Wehner: Department of Government, London School of Economics and Political Science 


\section{Acknowledgments}

This edited volume presents an updated series of papers that were first presented at a workshop jointly organized by the World Bank and the Transitional Islamic State of Afghanistan in April 2003.

The workshop was proposed by Nick Stern, then Chief Economist of the World Bank, and Ashraf Ghani, Minister of Finance of the Transitional Islamic State of Afghanistan. Materials for the workshop were prepared with guidance from Alastair Mckechnie, World Bank Country Director for Afghanistan, and Sadiq Ahmed, Director, South Asia PREM network, World Bank.

Linda van Gelder and Sarah Cliffe, from the World Bank, and James Wallar, from the U.S. Treasury, sent additional materials and useful comments. Many other colleagues from the Government of Afghanistan and from the World Bank are also acknowledged and thanked for their valuable contributions and comments. Al Friendly and Juliet Teodosio assisted in the preparation of the papers for this publication.

The study builds on an array of previous analytic and operational reports prepared by the Transitional Islamic State of Afghanistan, the World Bank, and other organizations_-very particularly including:

"Securing Afghanistan's Future: Accomplishments and the Strategic Path Forward-Prepared for International Conference, March 31-April 1, 2004." 2004. Kabul: Transitional Islamic State of Afghanistan and interna-

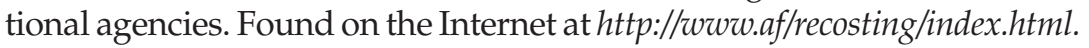
"Mid Term Budget Review." 2003. Kabul: Transitional Islamic State of Afghanistan.

Many more detailed explanations of the existing institutional arrangements are provided in a joint Afghanistan Research and Evaluation Unit/World Bank publication:

Evans, Anne, Nick Manning, Yasin Osmani, Anne Tully, and Andrew Wilder. 2004. A Guide to Government in Afghanistan. Kabul: AREU and the World Bank. 


\section{Acronyms}

AACA Afghanistan Assistance Coordination Authority (now abolished)

AFMIS

ARTF

CFA

CFET

CNRT

CSO

$\mathrm{DAB}$

DAD

DfID

ERC

ETTA

IARCSC

IMF

Interfet

INTOSAI

IOM

IPSAS

ISP

LOTFA

MAC

MoE

MoF

MoFA

$\mathrm{MoH}$

MoI

MoLSA

$\mathrm{MoPH}$

Afghanistan Financial Management Information System Afghanistan Reconstruction Trust Fund Central Fiscal Authority (East Timor)

Consolidated Fund for East Timor

National Council of Timorese Resistance (Conselho

Nacional da Resistancia Timorense)

Central Statistical Office

Da Afghanistan Bank (central bank)

Donor assistance database

Department for International Development

Expenditure Review Committee (of cabinet)

East Timor Transitional Administration

Independent Administrative Reform and Civil Service

Commission

International Monetary Fund

International Force in East Timor

International Organization of Supreme Audit

Institutions

International Organization of Migration

International Public Sector Accounting Standard

Individualized salary payments

Law and Order Trust Fund for Afghanistan

Ministerial Advisory Committee

Ministry of Education

Ministry of Finance

Ministry of Foreign Affairs

Ministry of Health

Ministry of Interior

Ministry of Labor and Social Affairs

Ministry of Public Health 


$\begin{array}{ll}\text { MoWA } & \text { Ministry of Women's Affairs } \\ \text { MRRD } & \text { Ministry of Rural Rehabilitation and Development } \\ \text { MUDH } & \text { Ministry of Urban Development and Housing } \\ \text { NCC } & \text { National Consultative Council (East Timor) } \\ \text { NDF } & \text { National Development Framework } \\ \text { NDP } & \text { National Development Program } \\ \text { NSC } & \text { National Security Council } \\ \text { NSP } & \text { National Solidarity Program } \\ \text { OAA } & \text { Office of Administrative Affairs } \\ \text { OECD } & \text { Organisation for Economic Co-operation and } \\ & \text { Development } \\ \text { PAREM } & \text { Public Administration Reform and Economic } \\ & \text { Management (program) } \\ \text { PBU } & \text { Primary Budget Unit } \\ \text { PEFM } & \text { Public Expenditure and Financial Management } \\ \text { PMU } & \text { Project Management Unit } \\ \text { PPU } & \text { Procurement Policy Unit } \\ \text { PRR } & \text { Priority Reform and Reconstruction Decree. } \\ & \text { This authorizes enhanced salaries for restructured } \\ & \text { ministries and departments. } \\ \text { PRSP } & \text { Poverty Reduction Strategy Paper } \\ \text { PWC } & \text { PriceWaterhouseCoopers } \\ \text { SBU } & \text { Secondary budget unit (including provincial } \\ & \text { departments) } \\ \text { SOE } & \text { State-owned enterprise } \\ \text { SRSG } & \text { Special Representative of the Secretary General } \\ \text { TA } & \text { Technical assistance } \\ \text { TFET } & \text { Trust Fund for East Timor } \\ \text { TISA } & \text { Transitional Islamic State of Afghanistan } \\ \text { TSA } & \text { Treasury Single Account } \\ \text { U.N. } & \text { United Nations } \\ \text { UNAMA } & \text { United Nations Assistance Mission in Afghanistan } \\ \text { UNDP } & \text { United Nations Development Programme } \\ \text { UNHCR } & \text { United Nations High Commissioner for Refugees } \\ \text { UNICEF } & \text { United Nations Children's Fund } \\ \text { UNTAET } & \text { United Nations Transitional Authority in East Timor } \\ \text { USAID } & \text { United States Agency for International Development } \\ \text { WB } & \text { World Bank } \\ & \\ & \end{array}$




\section{Glossary of Dari Terms}

Agir

Babs

Fasils

Furmaan

taknini

Gozars

Karmand

Loya jirga

Mafawk-i rutba

Meshrano Jirga

Mujahidin

Mustoufiat

Mustoufie

velayat or

Mustoufie

velayat

Rasmi gereeda

Safayi

Sharwali

uluswali

Sharwali

wolayat

Shura
Government staff hired on fixed-term contracts

The six major expenditure codes:

1000 personal emoluments

2000 services

3000 tools and materials

4000 maintenance and repairs

5000 land and structural equipment (capital)

7000 subsidies, grants, contributions, \& pensions

The more detailed line item expenditure codes, such as overtime, fuel, office supplies, and so forth

Legislative decrees approved by the president and cabinet

Neighborhoods (within a city)

Permanent, tenured government staff

"Grand council." The institution, which is centuries old, is a similar idea to the Islamic shura, or consultative assembly.

Beyond grade

House of Elders. Upper house of the National Assembly (Arabic: "fighters") In Afghanistan, the guerrilla rebel fighters who opposed invading Soviet forces and the Afghan communist government (1979-92).

The provincial Department of Finance

The official who is the provincial agent of the Ministry of Finance

Official publication of the Ministry of Justice, akin to an official gazette

Municipal service charge and property tax

Rural municipality

Provincial municipality

(Article 111 of the 1964 Constitution indicated that municipal councils are to be established by "free, universal, direct, secret election." Article 6, chapter 8 of the 2004 constitution notes that municipalities shall be established to administer city affairs.)

Council or association 


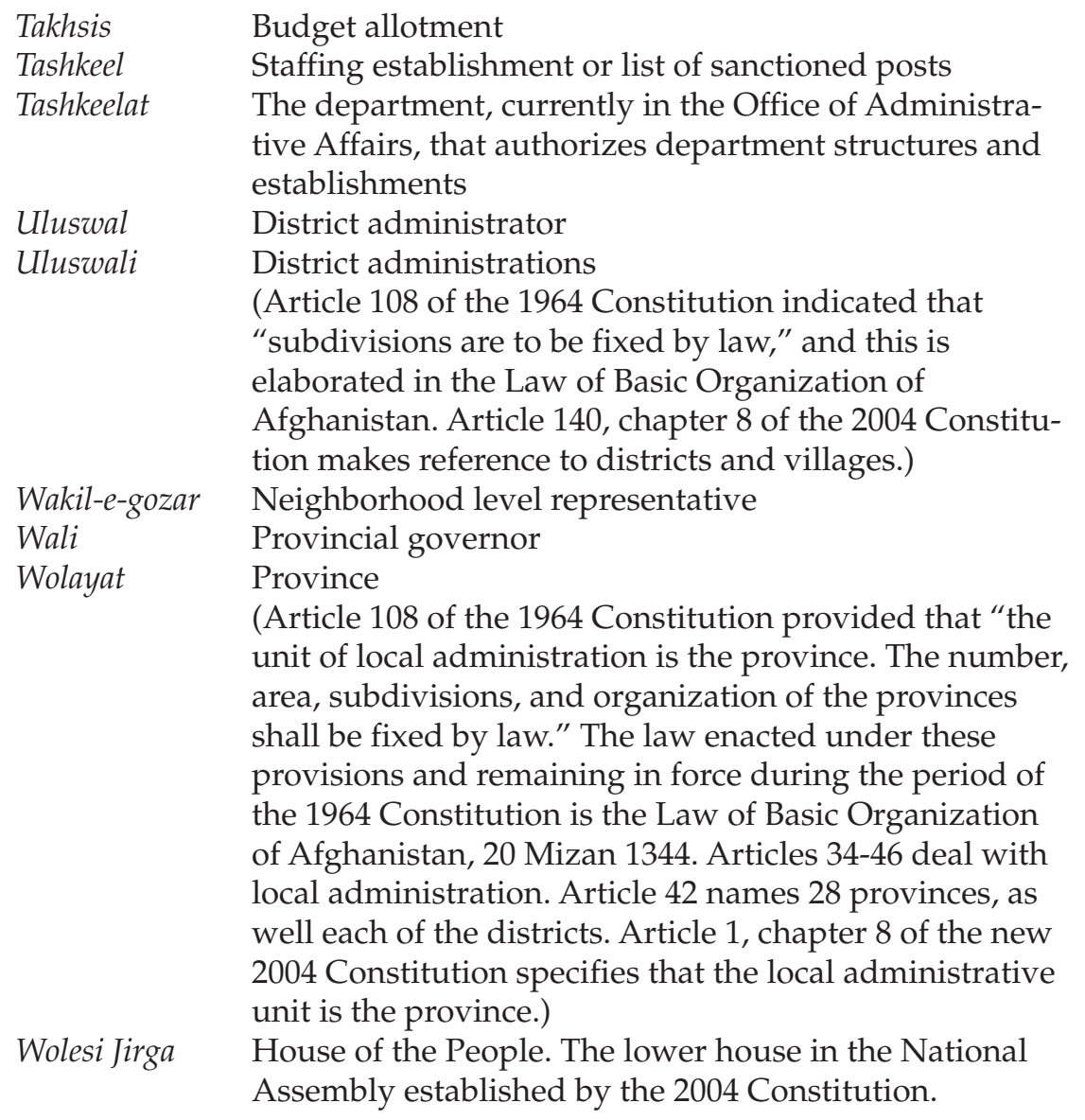




\section{Dates and Currency}

\section{Calendar}

Afghanistan uses the solar Hejra calendar. This calendar has twelve months, corresponding to dates in the western calendar as follows:

\section{Solar month Western month and date begins}

$\begin{array}{lll}\text { Hamal } & \text { March } & 21 \\ \text { Saur } & \text { April } & 21 \\ \text { Jawza } & \text { May } & 22 \\ \text { Saratan } & \text { June } & 22 \\ \text { Asad } & \text { July } & 23 \\ \text { Sonbola } & \text { August } & 23 \\ \text { Mizan } & \text { September } & 23 \\ \text { Aqrab } & \text { October } & 23 \\ \text { Qaus } & \text { November } & 22 \\ \text { Jadi } & \text { December } & 22 \\ \text { Dalv } & \text { January } & 21 \\ \text { Hoot } & \text { February } & 20\end{array}$

The current solar year, SY1383, began on March 21, 2004.

The fiscal year corresponds to the solar year and commences on March 21.

\section{Currency}

The unit of currency used in Afghanistan is the afghani (Af).

The exchange rate, as of March 16, 2004, and based open market buying rate, was:
1 U.S. dollar
49.93 afghanis
1 Pakistan rupee
0.87 afghani
1 euro
61.50 afghanis

Note: All dollar figures in text are in U.S. dollars unless otherwise indicated. 


\section{Preface}

Over the last two years a consensus has formed among all development partners in Afghanistan that the creation of a stable state is the cornerstone upon which security and stability for the ordinary Afghan woman and man will be built. It is only through the building of the state and state institutions that resources can be collected legitimately and effectively and then directed to the highest priority sectors, including the critical social sectors, to meet urgent poverty reduction needs, and also to the security sectors to ensure that the citizens and their property are protected.

The legitimate monopoly on the use of violence and control of public finances - the ability to raise and then spend revenues-are two hallmarks often used to define a state. The focus in the Ministry of Finance in Afghanistan is on the construction of a system of public finances that raises revenues as effectively and efficiently as possible, directs them to the country's highest priorities, reports on the expenditure of these resources, and then evaluates the results that have been delivered with these resources.

At the installation of the Interim Administration, the Ministry of Finance was confronted with a legacy of deficit financing, which had contributed to a massive depreciation of the afghani; and an economy that operated in at least three domestic currencies and at least two foreign currencies. On an administrative front the Ministry of Finance, and most other ministries, were filled with unskilled or deskilled staff. The advent of computerization in the rest of the world had coincided with the Soviet invasion, civil war, and then the Taliban regime-so there were no computers in the Ministry of Finance.

In the context of this imperative to put in place the systems of public finances needed to support a sustainable state, and against the background of neglect to institutions and their staff over the past 25 years, the Ministry of Finance, and the government more broadly, have made major strides. Major reforms have taken place in the areas of currency, tax and customs policy and administration, budget preparation, and other 
forms of financial management. Equally important are the policy decisions that have involved inaction - such as the decision to maintain rigidly a no-overdraft financing policy, which has been instrumental in ensuring that the currency has remained stable.

This book came out of a conference that was held at my request by the World Bank in Washington in April 2003. At that time, I posed two specific questions:

- At a time of limited resources-financial and human-what should a finance ministry do, and more importantly, not do?

- Are there successful examples of reform of finance ministries that could be used as a model for the reform of the Finance Ministry in Afghanistan?

The conference covered a broad range of issues and provided valuable insight into the first question and some of this is reflected in this book. In this regard, the papers in the book do not provide a summary of the conference proceedings; rather they represent the thinking that took place before, during, and after the conference in the light of both the ongoing debate and the evolution of the ground reality in Afghanistan.

What also became clear during the discussions is that there is not a single blueprint that can be followed in a post-conflict country. Over recent months, and so not reflected in the conference, the extent to which the legacy of the Soviet system has remained has become more evident. In terms of many broader economic management issues, Afghanistan has much to learn from the Former Soviet Union States. However, these lessons would be of much less relevance to other post-conflict countries, such as East Timor or possibly Iraq.

However, while each post-conflict country and reform experience is unique, much can be learned from each case. In this regard, this book does not set out to provide any sort of definitive manual or blueprint for reforming ministries of finance or building systems of public finance. Rather it forms part of a tapestry. Although raised in the context of Afghanistan, the questions considered in these papers have broader relevance for other countries seeking to restart economic and fiscal management following conflict. The papers provide insights into the more general questions of how to revitalize a ministry of finance or its equivalent, and focus it on priority tasks, in a turbulent environment with limited human resources.

I would like to take this opportunity on behalf of the Government of Afghanistan, and also the people of Afghanistan who will be the true beneficiaries of a functioning system of public finances, to express our appreciation for the work that has gone into this book. In particular, I would like to thank the authors of the papers and the editors who have 
prepared the materials contained in the book, and the World Bank for hosting the workshop that was the catalyst for this work. I would also like to note, with gratitude, that the major, necessary reforms will be achieved with the contribution of a number of very dedicated professional Afghans who are working in senior management in the Ministry of Finance at a small fraction of the wages that they would receive in other positions.

At one level, it is very gratifying for me personally as Minister of Finance to read these papers, and to see how far we have traveled toward building a sustainable system of public finances. However, the papers also bring into stark relief how far we still have to travel to build the systems that are needed to ensure that the state can function and deliver even the most basic services. We must not sit back content with our achievements to date. Hand-in-hand with our international development partners we must redouble our efforts. After 25 years of invasion and armed conflict, and faced with abject poverty and some of the worst social indicators in the world, the ordinary Afghan women and men demand that we move forward.

Ashraf Ghani Minister of Finance Government of Afghanistan 


\section{Introduction}

This edited volume builds on papers prepared for a World Bank workshop in Washington, D.C., April 7 and 8, 2003. The workshop originated with a request from the Afghan Minister for Finance, H.E. Dr. Ashraf Ghani, who posed key questions for the workshop to consider:

- At a time of limited resources-financial and human-what should a finance ministry do, and more importantly not do?

- Are there successful examples of reform of finance ministries that could be used as a model for the reform of the Finance Ministry in Afghanistan?

Although raised in the context of Afghanistan, these questions have broader relevance for other countries seeking to restart economic and fiscal management, following conflict. The papers provide insights into the more general questions of how to revitalize a ministry of finance or equivalent, and focus it on priority tasks, in a turbulent environment with limited human resources.

These papers cover two broad themes in the recent reform of fiscal and economic management in Afghanistan.

The first part, The Journey So Far, sets out the impressive policy and institutional reforms that the Interim and Transitional Administrations have made since the Bonn conference in November 2001. It provides some details of the challenges faced by the Ministry of Finance, and very particularly the complexities of managing intensive donor interest and significant volumes of development assistance, while balancing the need for responsiveness to donor priorities with a concern to build institutional strengths of the public sector. The section notes the complexity of the vested interests that had built up within the administration during the Soviet and Taliban periods, and the need to revive, while simultaneously reforming, the fiscal management processes.

Prepared by Bill Dorotinsky and Nick Manning. 
With imperfect institutions and very limited capacity, macroeconomic management over the past year or so has nevertheless been sound in Afghanistan-including a conservative fiscal stance (no-overdraft policy), reasonable control over inflation, and successful currency reform. However, finding a workable structure for the Ministry of Finance in an environment of weak local capabilities and fast-changing flows of technical assistance, of varying quality, has been a persistent theme.

The particular problems faced in executing the budget outside of Kabul are explored in some depth. In a country with shattered infrastructurefew telephones and even fewer passable roads-paying salaries and implementing government programs outside of the capital, however modest, presents overwhelming logistical challenges.

Overall, the Journey So Far is a story of how a guiding vision-that the budget should and must be the primary vehicle for developing and then implementing policy - has shaped the renewal of the Ministry of Finance. As budget making has evolved in Afghanistan, the government has significantly increased its control over the allocation of resources. The first budget, for instance, was primarily descriptive-largely summarizing the probable recurrent costs of running government and the bilaterally funded development or reconstruction projects. Since then, the budgets have become more prescriptive and are increasingly used as tools for forcing policy tradeoffs and allocating both cash and in-kind contributions to the government's highest priority tasks.

The recurrent budget has been transformed into a predictable source of funding to implement explicit government policies. The progress in the development budget is even more striking as the complexity of the task in a post-conflict environment cannot be overstated. The diversity of sources of funds and of accountabilities for execution, and the multiplicity of donor interests, together present a picture of Byzantine intricacy. In sum, the development budget must include items over which the government has no direct control and must introduce the principle of hard constraints in what appears to be an unbounded supply of stand-alone projects. The Journey So Far concludes with a brief overview of other post-conflict settings, and identifies four stylized phases through which development budgeting evolves:

- Project shopping list. Immediately at the end of the conflict, and often in the absence of either an expenditure plan or a national government, donors undertake emergency bilateral projects. These often take place under the auspices of a United Nations appeal, in which the projects identified by individual international agencies are aggregated together and marketed to donors. Donors choose the projects they like from the list. 
- Prioritized project list. The next stage is when the government prepares a prioritized spending plan and donors are asked to fund projects that are on this plan. In this way the government's development plan begins to emerge from shopping list.

- Sector program list. The third stage can involve the preparation of a coherent sectorwide approach rather than a list of priority projects within a sector. This program would include development and operational expenditure components and provide some information on the overall vision for the sector and the standard of service that is to be delivered. Donors would then be asked to fund the overall sectorwide program, rather than just picking up a single project within that program.

- Budget support. The final stage is when donors fund the budget rather than hypothecating their funds to a particular sector or a project within that sector.

Afghanistan currently sits somewhere between stage two and stage three.

With the scene set, Current Priorities then explores the fiscal and economic management tasks that the Ministry of Finance is now confronted with. The section opens with a review of the strategic options for structuring the Ministry of Finance, and the additional challenges and opportunities presented by the new constitution. The revised budget law is perhaps the most significant and far-reaching of the institutional reforms planned. The significance of the municipalities as a potential platform for enhanced service delivery to an increasingly urbanized population is also noted.

One of the most fundamental post-conflict choices is whether to build upon what exists (if anything) in terms of policies and institutions, or begin again. Delay can preempt the choice as the "window of opportunity" to start afresh closes relatively quickly, as interests become entrenched and better organized. In the case of Eritrea, the government took advantage of the window of opportunity in the immediate aftermath of independence to pursue important economic policy reforms. Uganda also made rapid progress with basic policy reforms after the crisis. The political process mandated by the Bonn Agreement gives the Transitional Administration of Afghanistan the ability to legislate by decree, which constitutes a window of opportunity at least for certain types of reforms.

The choices confronting government are as much about managing the donors as about managing the country. A second, concurrent choice involves use of technical assistance and foreign expertise, frequently made by default as the new administration lacks capacity to perform core state functions or manage foreign assistance. In Afghanistan, there is clearly a risk of fragmented and irrelevant technical assistance, in many of 
the line ministries even more than in the Ministry of Finance. However, the option of foreigners filling key line positions is probably not viable or advisable, although judicious use of expatriate Afghans on temporary contracts in such positions may work out well. Clearly the government needs to have the capacity to productively absorb external policy advice and to know when to say no.

The section ends with the answers to the questions that the April 2003 workshop posed-a specific agenda for reform and restructuring of the Ministry of Finance.

This edited volume is a contribution toward practitioner debate within Afghanistan and even more broadly. It is not exhaustive and much remains to be explored concerning progress and options for reform, for example, fiduciary management of public resources and of options for public sector pay policy. 


\section{PART I \\ The Journey So FAR}





\section{1 \\ Fiscal Management in Afghanistan Major Achievements and Current challenges}

\section{Introduction}

Afghanistan has made major strides forward in fiscal management over the last two years. Recent reforms have provided Afghanistan with the simplest customs regime in the region, while the computerization of Treasury operations in Kabul provides a strong basis for moving forward. Measures to heighten donor coordination through the development budget process and through encouraging donor sector specialization have led to the more effective utilization of scarce resources. Despite this progress there is still a long way to go.

Fiscal management is starting from a very low base in Afghanistan. The conflicts of the last three decades have led to the degradation of both physical and human capital. As an example, the lack of investment in these areas has meant that when the Interim Administration took office in January 2002, there were no computers in the Ministry of Finance. A further consequence of the conflict was that communication and other links with the provincial administrations were weak. Moreover, as discussed below, the frequent recourse to overdraft financing from the Central Bank meant that there was no focus on cash flow management or financial reporting.

Against this background, good progress has been made. The next two sections provide some background on the context within which fiscal management is taking place in Afghanistan. The following three sections outline progress in the areas of revenue, including collection, policy, administration, and forecasting; operating budget, including preparation and execution; and development budget.

This chapter has been written by Michael Carnahan. Comments and additional material were provided by Nick Manning, Peter Middlebrook, and Anne Evans. 


\section{The Consequences of Conflict on Fiscal Management}

Much has been written in the recent past about the low level of both the human and physical capital in Afghanistan. ${ }^{1}$ The conflicts of the past 25 years both degraded the existing capital and precluded new investment. Specifically, a country at Afghanistan's level of development could have expected considerable resources over the previous 25 years from development agencies, had it been at peace. This low level of human and physical capital impacts across all areas of the government's operations, from the poor level of communications infrastructure linking the central ministry with its branches in the provinces, through to the lack of both computers and national staff trained to use them.

However, there are three specific consequences above and beyond these general limitations that have restricted the ability of the government to manage the fiscal affairs of the State: the history of deficit financing, the history of nonaccountable covert financing, and the nature of the government that was agreed upon during the Bonn Process in late 2001.

Over the past 20 years, and increasingly during the Taliban period, any budget shortfall was financed not by levying additional taxes, but by printing new currency, or by incurring an overdraft with the Central Bankwith no intention to repay. The textbook macroeconomic impact of this policy occurred, with a dramatic depreciation of the afghani against other currencies. Over the last 25 years the afghani dropped in value against other currencies to $1 / 1,000$ of its previous value.

This depreciation has significant impacts from a social and economic point of view-particularly on people who held their wealth in afghanis over the period. However from a fiscal management point of view there is a range of additional impacts. If any shortfall of revenue over expenditure is simply met by printing additional money, then there is no reason to undertake the onerous and complicated task of forecasting revenue collections with any degree of precision or reporting on revenue outcomes until well after the event, if at all. Similarly, quarterly or monthly reports of spending, or any sort of cash flow forecasting, is an unnecessary output as traditionally the results of these reports and forecasts have no bearing on policy decisions. It has been a major, and ongoing, challenge to introduce the cultural change that sees the value in this work.

A second legacy is the approach of many key stakeholders to foreign assistance. Many ministers have been the recipients-either directly or indirectly-of covert assistance over the last three decades. Such assistance was generally provided in cash to individuals, not institutions. This approach to assistance has formed two mental approaches that inhibit good fiscal management. First, the providers of this assistance had an interest in minimizing the transparency and accountability around the use of these funds- 
so the recipients are confused by the current requirements for disclosure and reporting around the current international assistance. Second, the funds were provided on an ad hoc basis. This unpredictability, coupled with the lack of transparency, fostered an approach to expenditure that did not involve budgets or planning. Rather, it appears to have involved the petitioning of the recipient of the covert assistance by different groups, with unilateral decisions being made on a case-by-case basis.

In this context it is interesting to note that the budgets under the Taliban appeared to involve the majority of the budgeted funds being kept in various contingency funds or allocated to a very small number of ministries with unclear mandates. In this regard the budget was more a statement of general policy intent, rather than the expenditure plan of the State. Some papers for the 1380 budget suggest that around 80 percent of budgeted funds were kept in these contingency funds. In preparing the 1381 budget (see below) there was considerable debate between international advisers and ministry staff over this issue.

The final issue that impacts on the ability to undertake significant fiscal reforms in Afghanistan was the nature of the coalition government installed under the leadership of Hamid Karzai at the Bonn Conference in December 2001 and of the transitional administration established after the session of the emergency loya jirga (grand council). Many of the groups that make up the coalition-the Northern Alliance and other forces that fought the Taliban-remain deeply divided, having in common only the fact that over the previous 20 years they opposed the same enemy. Both the interim, and subsequently the transitional, Council of Ministers represent a compromise based on the political exigencies of the day. They contain a number of disparate actors, many of whom had fought each other at different times in the country's recent history.

The lack of electoral mandate, party structure, or coherent platform among ministers has made the job of the finance minister extremely difficult. Budgets embody complex policy negotiations. The group benefits that come from a properly functioning system of public finances and a disciplined fiscal policy generally relate to the provision of a stable macroeconomic environment, characterized by low and predictable inflation and interest rates. This is conducive to private sector investment and associated economic and employment growth. However, it is in each individual minister's interest to gain higher spending levels that deliver benefits to their constituents, since the costs of higher inflation or lower investment are spread across the entire government.

In more mature systems with an elected party there is generally a grudging acceptance of the role that must be played by the finance minister to deliver a responsible fiscal policy that supports the stable macroeconomic environment and associated economic growth —and the leader of the party 
is the most mindful of this role. However, in Afghanistan where members of the appointed Council of Ministers are likely to be on opposite sides in forthcoming Parliamentary or Presidential elections, driving major reforms is significantly more difficult.

\section{Fiscal Management in Afghanistan}

Before outlining the major achievements and challenges in fiscal management it is worth outlining the de jure structure of the system, to both situate the discussion and to allow a comparison of how far from the ideal system the current operations are.

Afghanistan has two levels of government. The first and largest is the central government, which has legal responsibility for all major spending areas including health, education, foreign relations, defense, and policing. The second level encompasses the municipalities, which are legally entitled to collect revenues and use these for the provision of local public services, such as water and sanitation or waste collection.

The provinces do not have an independent legal existence. Rather they are the administrative arms of the central government. Provincial governors are appointed and dismissed by the central government (Evans and others 2004a). The customs houses in the provinces are central government institutions and all revenues are the legal property of the central government. Once the overall budget has been agreed, including with the identification of revenue sources, each ministry provides an allocation for each province. If the amount of revenue that is physically collected in a province is less than the amount that is needed to fund the activities of each of the ministries in the province then physical cash is transferred into that province. If on the other hand the amount of revenue collected is greater than the amount that is needed to fund the aggregated spending of each of the ministries then the surplus funds are physically transferred out of that province. Historically these transfers took place at the end of the fiscal year. Because expenditure and revenue has been set at an aggregate level, the overall level of transfers of cash to and from different provinces should net out.

In a functioning system with effective control this "net flow" approach can be very effective. However, this situation is complicated because the bulk of the customs revenue is collected in 5 of the provinces with the other 27 needing transfers of cash to meet their expenses. In addition, over the recent past, regional power holders in these five provinces have channeled these expenditures into their own priorities-including to fund their militias. As an interim step to address this problem, the Government has decided to replace the "net flow" approach with a "gross flow" approach. The policy is that all funds are collected and deposited in central accounts. Allocations are then explicitly made back to the provinces for their expenditure- that 
is, the provinces do not have the authority to spend revenue collected in that province-even for expenditure that is in the budget.

\section{Progress in Revenue}

The ability to fund the operations of the state from domestic revenue is a fundamental prerequisite for true sovereignty. In Afghanistan, significant progress has been made in the actual collection of revenue over the life of the Interim and Transitional Administration. In preparing the 1381 budget, a revenue estimate of $\$ 83$ million was included. The actual revenue collection was $\$ 132$ million. Of this, \$68 million was collected in customs revenues, while the remaining $\$ 64$ million was collected in taxation revenues and other fees and charges. The revenue estimate in 1382 was increased significantly, to $\$ 200$ million. This partly reflected a reestimation of the revenue base following the better than forecast revenue performance in 1381, but also an increased enforcement and compliance effort. This estimate was considered to be extremely ambitious by the international community; however, end-of-year reports indicate that actual collections will be close to $\$ 200$ million. $^{2}$ Records on revenue collection for the period of the Taliban are not available to allow comparison. However, this amount represents less than 40 percent of the operating expenditure and around 4 percent of GDP, indicating that there is both the need and the scope for a considerably heightened revenue effort in Afghanistan.

Currently a considerable amount of illegal collection of revenue takes place and this is both a challenge and an opportunity. This means that with an enhanced security and compliance effort it will be possible to increase revenue collection significantly without the negative impacts on economic activity that usually accompany such increases.

In Afghanistan, as in many countries with weak administrations, the major source of revenue has been customs revenue. This is because control over border entry points is generally quite good. Currently around 50 percent of revenue comes from this source. The challenge over the coming five years is to increase the other revenue bases so that only 20 to 30 percent of revenue comes from customs and the remainder from taxationincluding direct income taxation, indirect taxes, and royalty taxes.

\section{Revenue Collections}

The legislation makes it clear that all revenues collected by provinces and districts are national revenues, and provinces are merely the tax collectors. For some provinces, practice has been consistent with this view. In Bamyan and Wardak, for instance, all revenues collected are remitted to Kabul, and both provinces are fully dependent on Kabul for funding. In Faryab and 
Badakhshan, provincial revenues have been used to help fund their nonsalary budget, apparently with the approval of Kabul. In Herat and Kandahar, on the other hand, revenues far exceed budget allocations primarily due to the prominence of customs duties. In these two provinces, the practice until recently has been that all provincial expenditures were funded through local revenues; and no transfers were received from Kabul. An ongoing challenge is regularizing the process through which these revenues are transferred to the central government accounts-rather than just on the basis of ad hoc requests from Kabul.

\section{Revenue Administration}

The major accomplishments in the area of revenue administration have involved both the restructuring of the revenue authorities and also the reform of the customs collection process. A five-year plan for the reform of the revenue authority has been prepared with an emphasis on: increasing revenue collection; improving clearance times; bringing customs tariff, exchange rates, and valuation in line with internationally accepted practices; enabling remittance of all customs revenues collected in the regions to the central treasury; improving the key customs infrastructure; reorganizing and rebuilding capacity of the Kabul and regional offices; building a stable and comprehensive legal framework for customs; and establishing effective enforcement controls.

The first year of the plan is currently being implemented. Starting with the senior management, a Deputy Minister for Revenue was appointed in May 2003 and he has subsequently appointed a new Director-General for Customs, a new director of airport customs, and a new director of the Kabul Customs House. Moreover, the majority of the directors of customs houses across the provinces have been replaced.

On the administrative side, the previous system of customs clearances that required more than 25 different forms and the signature of more than 25 officials-maximizing the opportunity for the extraction of bribes-is being replaced with the internationally recognized Single Administrative Document. This process also reduces the number of signatures required to four. This reform has been implemented in Kabul and is currently being rolled out across the other major customs houses.

A second administrative reform has been the reengineering of the flows of people and paper. The key theme has been to separate the decisionmaking official from the client. That is, the person applying for a government decision (for example, the clearance of goods) provides their papers to one person, but that person does not have decision-making authority. Rather the decision maker is kept separate and does not have any direct con- 
tact with the person who is requesting the decision. While this approach does not eliminate corruption and there is always scope for collusion between the different parties, it does make it more difficult.

The third major area of administrative reform is the creation of the Large Taxpayer Office in Kabul to focus on domestic revenue collection from the "top 100" tax-paying entities. In addition, there are plans to create "model offices" in the provinces that would handle medium-size taxpayers. These offices would be separate from the mustoufiat, and outside the normal provincial structure that reports through the governor. The government's objective is to continue to increase collections from customs revenue while reversing the balance between domestic taxation and customs revenue.

A fundamental feature of reform in revenue administration has been the efforts to centralize revenue- that is, to ensure that revenue reaches Kabul. The visible progress in this area has been the increasing amounts of revenue that have been provided by the provincial customs houses to the center. More significantly, the groundwork for sustainable flows of revenues has been laid: improving communications, changing recording and reporting processes, replacing key personnel in the provinces, and a small number of international staff deployed to the provinces.

Since August 2003, the treatment of revenues has changed. At that time, the bank accounts of all mustoufiats were frozen and two new accounts (one for revenues and one for expenditures) were established at the corresponding Da Afghanistan Bank (DAB) branch. Under the current procedures, each mustoufiat deposits all revenues in the Revenue Account from which only the Central Treasury can make withdrawals. This represents a major institutional change, as previously mustoufiats could meet their budget allotments from the central revenues that were collected in their provinces. However, given the difficulty of ensuring that all revenues collected in the provinces were spent only on budget items, the Government decided that this step was needed to ensure control over revenues. The Central Treasury sends instructions to DAB from time to time, depending on the level of balances accumulated in the provincial revenue bank accounts, to sweep the balances into a dedicated bank account at DAB in Kabul. In SY1383, the intention is that at the beginning of each month, the Central Treasury transfers funds to the expenditure bank account of each mustoufiat: normally one-third of the quarterly non-salary allotment, and in the case of Herat, one-third of both the salary and non-salary allotment.

\section{Revenue Policy}

Over the last 18 months, there has been one major reform in revenue policythe radical revision of the customs rates. A number of other reforms have 
been advanced, including land and income taxation and are likely to be announced and implemented as part of the 1383 budget. In the longer term, as the economy develops there will need to be an increased reliance on indirect taxation. Drafting of revisions of the administrative codes for both customs and taxation has also commenced.

The system of customs rates in Afghanistan prior to the reform was opaque and open to significant abuse. First, goods were valued using an artificially low exchange rate-with reports that different provinces "competed" with each other to attract imports through their province by offering lower rates to some clients. Second, there were more than 25 statutory rates ranging from zero through to 150 percent. Finally, many goods were charged a rate of duty that related to the weight, rather than the value of the goods. Each of these aspects opened the way for corruption as the customs officials could either use a different exchange rate, or classify goods into a different category, or arbitrarily use a weight-based rather than a valuebased system.

The reform of the customs system replaced the artificial exchange rate with the market rate, replaced the large number of bands with four rates, and removed the use of non-value-based systems for the calculation of customs duties. It also involved the adoption of the Harmonized System of Tariff Classification of the World Customs Organization and follows the WTO principles with respect to Customs Valuation. The reform was strongly revenue positive, with an expected increase in revenue of around 100 percent. Reflecting the very low level of protection by regional standards, the top tariff rate was 16 percent, with the vast majority of goods subject to a tariff rate of 8 percent or below. This proposal was the subject of considerable consultation both within the government and with the major merchant groups and was introduced in mid SY1382.

Upon the introduction of the tariff, there was organized opposition to it-based out of Herat. A small but politically powerful group of merchants refused to comply with the new rates. Following extensive negotiations it was agreed to introduce a new lower rate at 2.5 percent, to move some goods into lower categories, and to delay the implementation date until the start of SY1383. However, importantly, the basic structure of the reform, including the use of the market-exchange rate, the simple rate structure (increased to five rates from four), and the elimination of alternative valuation techniques, was maintained. ${ }^{3}$

Notwithstanding the concessions that were made to ensure the passage of the tariff, this represents a very significant reform, and one that lays the basis for strong customs revenue collections into the future. Arguably, given the criticality of domestic revenue for ongoing independence and sovereignty, this may be the single most significant reform that the government has undertaken. 
A number of other revenue policy changes are either in the pipeline or have been approved by cabinet and are awaiting implementation. These include a radical simplification of the income tax code, with a proposal to align the top personal rate with the corporate income tax rate at 20 percent for both administrative and compliance simplicity and to reduce the scope for opportunistic tax minimization practices to exploit any differences; and a proposal to reform the land tax-which is currently so high that there is no compliance with it.

Finally, there has been ongoing pressure to address major revenue policy issues through sectoral legislation, such as that proposed for taxation of investment and mining. Although it is understandable that sector ministries may wish to retain control over the rates for resource royalty taxation, the Ministry of Finance has strongly argued that this responsibility needs to be vested in the finance minister. These issues are likely to be addressed as part of entry into an IMF Staff Monitored Program-requiring that the Minister of Finance have responsibility for all revenue and taxation policy issues.

\section{Major Challenges}

While there has been significant progress in the area of revenue collection, policy, and administration, major challenges remain. Over the last two years considerable technical assistance has been provided to the Ministry of Finance, both through IMF and World Bank missions and through bilateral development partners, to develop new revenue systems and policies. However, there has only been traction in this area when the national staff have been in place and empowered to move the agenda forward, as was the case in the customs area. The process from idea through to implementation needs to be carefully mapped and the bottlenecks addressed. For example, there is no shortage of people able to draft policy proposals in English; there is, however, a shortage of people able to translate these into Dari and Pashto, with the accompanying explanatory and advocatory materials to support the passage of the policy through the cabinet and then to gain popular support. The absorptive capacity of the Ministry of Finance, the government, and the community for revenue policy and administration needs to be carefully understood.

It appears that the central government is now getting the bulk of legally collected revenues through the customs houses, and that the reporting of these revenues is increasing. However, a second challenge is that there may have been an increase in regional power holders directing a greater portion of trade flows through informal channels-that is, importers evade formal customs duties, but are still subject to the levies imposed locally. 
A third major challenge to the collection of revenue relates to the response of most international development partners who insist that the Government of Afghanistan must increase its domestic revenue collection as a condition for the ongoing receipt of assistance. Their vehemence in arguing for this is only overshadowed by their insistence that the contractors who are implementing their aid programs not be subject to any taxes or duties. In many cases, they also argue that non-development-related businesses also should be given generous concessions from taxes-as an encouragement to these firms. This results in complexity for the tax administration, which is already stretched in such a post-conflict setting, and financial losses for the Government (in 1382, one estimate suggested that revenue lost due to concessions to international development partners could be as high as \$200 million).

A fourth challenge is to implement the provisions of the new Constitution regarding a single Treasury account. A number of ministries are unfamiliar with the concept that state revenues should be delivered to a central account and then allocations made through a legal budget and appropriations process. Ongoing work is needed over the coming 12 months in this area.

Finally, more work is needed in the area of revenue reporting and forecasting. It is necessary to clarify the responsibility for reporting on revenue collections between the old Revenue Department, and the new and reformed Treasury. It is particularly complicated as, while traditional drivers of revenue such as economic activity or employment growth are significant, perhaps the major variable determining the amount of revenue collected relates to the degree of political pressure that can be brought to bear in certain areas, including regional areas, to ensure greater compliance with the laws.

\section{Developments in the Ordinary Budget ${ }^{4}$}

The operating or ordinary budget provides operating expenditure, including wages and salaries, operations and maintenance, and some capital expenditure. Legally the operating budget is appropriated at the level of ministries. Ministries then allocate the expenditure to budget units within their ministry (for instance, the Ministry of Education to the provincial office of the Ministry of Education in Farah). In this section of the paper, the budget preparation process for 1381 and 1382 (corresponding to 2002-03 and 2003-04) will be discussed. The execution of these budgets will also be discussed. In both the areas of the preparation and the execution of the operating budget significant progress has been made. Going forward, the larger challenges will be in the execution of the operating budget, rather than the preparation. 


\section{Ordinary Budget Preparation ${ }^{5}$}

\section{Solar Year 1381}

The Transitional Administration took office on December 22, 2001. However, for the first months of the administration almost nothing happened because the administration had almost no money and ministers had little experience in public administration. There were also at least four other major impediments to preparing the budget. First, there was no statement of actual expenditure for 1379, and an examination of the 1380 budget revealed that well over half of the funds were allocated into either discretionary funds controlled by the President or the Ministry of Finance, or to the Ministry for the Promotion of Virtue and Eradication of Vice. Second, there was no clearly agreed establishment (staffing structure) from which the wage bill could be derived. Third, as discussed above, the staff in the ministry saw little reason to move from the processes that they had been using, which appropriated most resources into discretionary funds. Finally, around half of the ministries did not exist during the Taliban regime-rather, they were created during the Bonn Meetings in December that created the Interim Administration. Accordingly, these ministries had little experience with budgeting.

Against this background, the preparation of the 1381 budget was a challenge. The first stage of the process commenced in January and involved the Ministry of Finance and the line ministries meeting to discuss staffing numbers. This presented a major challenge because the establishment was being managed from the Office of Administrative Affairs (OAA), while the budget side was being managed from the Ministry of Finance. However, a draft budget was prepared jointly by international advisers and senior officials of the Ministry of Finance. Considerable disagreement surrounded this budget-particularly as the new cabinet had little individual or collective experience with budgeting. There was also no agreement at that time around the future size of the defense force or the police force-or indeed the estimate of the current number of men under arms. The security ministries argued that 700,000 men were under arms in the country; estimates from other sources put the figure around 30,000 to 40,000, or possibly lower.

A remaining challenge was to assess the scale and nature of expenditure that was occurring off-budget. This included expenditure that could come on budget in a quite straightforward way-such as the use of revenues earned in embassies overseas to fund those embassies and the Foreign Ministry more broadly; expenditure from revenues collected at the provincial level that were not reported to the center; and expenditure from assistance provided by neighboring countries.

Given the short period of time available to the Interim Administration to prepare the 1381 budget, it used a one-month appropriation bill to cover 


\section{Box 1. Passage of the 1381 Budget}

The finance minister prepared a draft budget for consideration, but time did not allow for consideration of the budget by cabinet members. Accordingly, the finance minister recommended and the cabinet agreed to use $1 / 13$ of the annual draft appropriation as the appropriation for the first month of 1381. During that first month, the cabinet debated the budget for the remainder of the year. Although it reached quite detailed agreement in some cases (including reference to staffing levels) the agreement was significantly looser in other areas, defense in particularreflecting the political realities and the need to maintain an ongoing consensus in the cabinet. Following the cabinet agreement a budget decree was drafted, approved and, with the appropriation schedule attached, was agreed to by the cabinet and passed into law on 17 Hamal 1381 (April 7, 2002).

Among the decree's general policy pronouncements was the requirement that no wage increases should occur until reform of the public sector had begun, a policy that was effectively reversed six weeks after the decree's passage when an additional meals allowance was introduced. However, the clause forbidding overdraft financing has been rigidly enforced. Summary material, including the budget decree and the appropriation schedule, was provided to donors in English, and the appropriation schedule and decree were also circulated to Ministers in Dari.

Source: Evans and others (2004a, p.6).

the first month, while developing a more comprehensive full-year budget. Information was poor, particularly in relation to staffing-with a widespread confusion about the concepts of actual staff and authorized establishment. The choice of exchange rate also presented significant problems. With the budget being over 80 percent donor funded, some argued for presenting the budget in U.S. dollars. However, with the majority of expenditures being on local purchases (particularly local wages), the overwhelming political priority was to maintain the nominal value of the wage that civil servants collected on a monthly basis.

Presenting the budget in U.S. dollars would have held civil service salaries hostage to unpredictable exchange rate fluctuations. The 1381 ordinary budget was approved for $\$ 460$ million - some $\$ 150$ million of it for staffingagainst which domestic revenue totaled some $\$ 83$ million or 18.5 percent. The balance, some $\$ 377$ million, was financed through external donor assistance. 


\section{Box 2. The Politics of the Defense Budget}

During the first month of 1381, the cabinet debated the budget for the remainder of the year. The result included a defense budget amounting to $\$ 100$ million with little detail provided. Criticism of that looseness, while easy, fails to appreciate the complexities of the situation. Put simply, the views of key stakeholders around different aspects of the defense expenditure were not sufficiently close in their views to make it possible to put together an explicit budget that would have kept all parties at the table. A more explicit budget would have seen at least one and possibly more key military stakeholders leave the very tenuous government coalition.

\section{Solar Year 1382}

The preparation of the operating budget for 1382 was a much more detailed process. First, the preparation process started with the Ministry of Finance (MoF) having over six months of actual expenditure data, at least from the ministries in Kabul and in some cases from the provinces. Second, there was considerably more time to undertake the budget preparation processwith preparation starting in earnest in November, as compared to February in the previous year. Finally, there was considerably more understanding among a number of ministers about the centrality of the budget and the importance of engaging actively in the preparation process.

The 1382 process initially operated on a methodology that used the actual expenditure for the first six months for 1381 as a basis for a projection of the likely expenditure for the second six months, to provide an estimate of the annual expenditure. This expenditure was then deemed to be the base level of expenditure for 1382. Expenditures above this base level were characterized as new policy proposals by ministries and required separate justification.

A major difference between the 1381 and the 1382 process was that there were two sets of meetings held in the preparation of the 1382 budget. The first set of meetings was between officials of the Finance Ministry and the spending ministries. These meetings allowed some agreement around the base budget and preliminary discussion over the new spending bids. The second set of meetings were chaired by the Minister of Finance and brought together the ministers of each of the programs under the National Development Framework to discuss the budget.

These meetings highlighted one of the most critical lessons in developing financial management systems and capacity: in many cases the benefits of a process are not realized immediately-rather, they lay the foundations for improvements down the track. ${ }^{6}$ In this case, the major ben- 
efits from these meetings were not realized in the 1382 budget process, but they laid the foundations for the very successful 1382 midyear review and the 1383 budget.

In the short term, however, the major outcome of the meetings with officials was to bring to light that a separate process was being undertaken by budget department officials with their line ministry counterparts and that two sets of budget numbers were produced-those produced by a joint team of Ministry of Finance staff and international advisers and being discussed at the officials meeting; and a set of numbers that were agreed subsequently by MoF Budget Department staff and their counterparts in line ministries. The consequence was that two sets of numbers were coming into the cabinet discussions of the budget.

The ministerial level meetings were designed to perform the role of a Budget Committee of the-reviewing the expenditure plans and ultimately bringing together an agreed budget for cabinet consideration. However, as the level of understanding among the ministers attending was variable, much of the meetings involved the Minister of Finance effectively chairing a discussion seminar on the role of budgets, budgeting, program management, and, more broadly, development.

This capacity building was essential and has contributed to a much better budget process in 1383. However, the situation in late February 1382 was that there was no agreed budget and a gap between ministry bids (over $\$ 800$ million) and the eventual budget figure (\$550 million). At this point two major political economy decisions were taken. The first was to shed the concept of base budgets. It was considered that this concept was too sophisticated for the cabinet to consider and would lead to confusion-particularly as many ministries had not bought into the 1381 budget. The second decision was to give the 28 smallest ministries (which comprised about 20 percent of the budget) the budgets that they had agreed with the MoF officials in the bilateral agreements discussed above. While these figures were generally 10 to 30 percent above the amounts initially agreed, the Ministry of Finance considered that it would have been virtually impossible to agree on a budget if much of the time was spent negotiating with every ministry in the cabinet. Moreover, such an approach would have precluded the detailed discussion on a few large ministries that was particularly important.

Seeking agreement over the remaining five large spending ministriesDefense, Interior, Education, Health, and Foreign Affairs-required a difficult balancing act. All argued that they needed additional staff and higher salaries for their staff. In the political context, with the lack of any collective cabinet responsibility, the finance minister was not in a position to put a recommendation to cabinet. Such a move would have seen the finance minister being blamed by each of the ministers for their budgets. Instead, the finance minister presented a matrix of options, includ- 
ing salary and staffing combinations, to a group of senior cabinet ministers, chaired by the President, and required the collective group to make the decision. The first decision that the senior group made was to cut the budgets of the 28 small ministries-ironically back to the original level that the Finance Ministry had in its internal papers, but had not made public. After this initial move, the senior ministers then simply divided up the remaining budget-each taking a major reduction from the ambitious claim that they had made.

The 1382 budget was passed into law on 26 Hoot 1381 (March 17, 2003), four days before the start of 1382 . The budget provided for spending of $\$ 550$ million to be financed by $\$ 200$ million of domestic revenue, contributions to the Afghanistan Reconstruction Trust Fund (ARTF) of \$250 million, and contributions to the Law and Order Trust Fund for Afghanistan (LOTFA) and the Army Trust Fund of $\$ 100$ million. The domestic revenue figure of $\$ 200$ million not only represented a major increase from 1381, but coincided with the amount appropriated to the Ministries of Defense and Interior-to increase the likelihood that these two ministries that have a major role to play in facilitating the collection of revenue would be supportive.

\section{Midterm Budget Review}

The operating budget was reviewed in August-September 2003, and taken to cabinet in September. The decision to review the budget at midyear reflected a number of issues, including: the disconnect between the established staffing levels and the authorized budgets becoming clearer, a stronger Ministry of Finance team with a greater capacity to both produce and analyze information, an increase in the capacity of line ministries, and a greater availability of data. In particular, the Ministry of Finance's rigid enforcement of the budget decree, requiring the presentation of staffing lists in advance of the release of any salary payments, produced a considerable amount of information about the actual level of staffing in the ministries. Also some interest was expressed in revising the budget in advance of the donors' conference to be held in September 2003.

The midyear review involved the forming of a committee at senior officials' level from the Ministry of Finance, Ministry of Reconstruction, the Civil Service Commission, and the Office of the President. This committee met with each ministry to review the actual spending and staffing in each ministry, the budgeted level of spending, and the authorized establishment. A major outcome of the review was the much closer aligning of the establishment levels and the budget appropriations. This laid the foundations for a very successful 1383 budget process and the Ministry of Finance was able to take a draft budget to the cabinet that had been agreed to by 32 of 33 ministers. 


\section{Ordinary Budget Execution}

Developments in budget preparation and budget execution have not moved forward at equal pace. This is mainly because developments in budget preparation generally involve a fewer number of people and are more amenable to injections of technical assistance that can yield rapid results. Developments in budget execution all revolve around building the capacity at a very low level to implement the systems. In this regard, the Ministry of Finance has recognized that the focus over 1383 and beyond must be on the building of financial management systems and the execution of the budget.

Significant developments still need to be made in the budget preparation side, including the preparation of a medium term framework, and a closer linkage between the development and operating budgets, particularly in the area of the relationship between capital investments and operations and maintenance expenditure. These areas will be addressed somewhat naturally as Afghanistan moves toward a PRSP framework. Against this background, the key challenge for the Ministry of Finance is in improving the budget execution. Executing the non-salary budget is a particular problem at the provincial and district levels and is explored in a later chapter.

APPROPRIATIONS AND ALLOTMENTS. The budget provides the primary budget unit (PBU) with a delegated political authority to spend. The PBUs prepare allotments for their central and provincial units (secondary budget units), which are then approved by the Ministry of Finance. ${ }^{7}$ In essence, traditionally each PBU proposes the quarterly allotments for each of its secondary budget units, subject to confirmation by the Ministry of Finance.

A number of reforms will be introduced into the allotment process in 1383 to streamline the process and allow a more efficient implementation of the ordinary budget. The initial budget allotment for the first quarter will be issued automatically by the MoF at the start of the financial year. At the start of the year, ministries are required to submit a plan for the apportionment of their ministry's annual budget between Kabul and the provinces (this information will also be used to issue allotments for the second, third, and fourth quarters).

The information provided by ministries on the planned apportionment of resources to provinces will be reviewed by the cabinet to ensure that the decision over the balance of resources between Kabul ministries and their provincial offices and the aggregate allocations among provinces are made consciously and transparently. The Ministry of Finance will also issue suballotments to each province automatically at the same time as the ministry allotment is issued. The province suballotment amount will be based on the amount that the ministry needs in each province during the year. 
The default allotment amount will be 25 percent of the total appropriation of the ministry in each quarter. However, ministries may review the proposed percentage distribution of the budget between quarters.

As approval of the 1383 budget was delayed, the MoF has issued default allotments based on expenditure in each location in 1382, as recorded in the Afghanistan Financial Management Information System (AFMIS), with adjustments for decisions in the 1383 budget. These initial suballotments will be updated when ministries provide information on their actual spending plans in each province for $1383 .{ }^{8}$

PAYROLL. The single largest expenditure is the payment of payroll. While the payment of various types of operation and maintenance expenditure and capital purchases are critical to the effective functioning of the government, it is the payment of payroll that generates the most political interest.

After the fall of the Taliban and the collapse in domestic revenue collection (combined with the decision not to engage in deficit financing), there was an agreement among the international community to establish a trust fund, managed by UNDP, to pay civilian government staff. Under the Trust Fund Agreement, it was considered necessary to bring the entire payroll material to Kabul for checking before the funds were released. Although this did provide pay to many staff under difficult circumstances, this centralization of the payroll has caused many problems resulting in significant delays in payment and has proved difficult to reverse. In the past, the mustoufiat would receive the cash for the quarterly allotment in advance, so that once the payroll had been verified, payment could proceed. But with centralization, all information is sent to the Treasury Presidency in the Ministry of Finance in Kabul. Although payrolls may be submitted and paid monthly, most provinces have switched to submitting their payroll after every three months, mainly due to the time commitment required for each trip (Evans and others 2004a). This situation confirms that funding from international sources can have significant unintended consequences.

Following significant delays in SY1381 in processing payrolls, particularly for the provinces, the timeliness of payroll execution appears to have improved in SY1382. Figure 1 measures delays as the average number of days between the date on which provincial pay was due, and the date on which the Treasury Department in the Ministry of Finance issued checks to the province.

It shows the delays in processing the first checks and in processing the last check issued. The delays in initiating the payroll have gradually diminished. However, the delays in making the last payment-although they came down-went back up at the start of SY1382. This is largely because the 1382 budget decree included a number of measures requiring greater report- 
ing and information transfer from the line ministries. A number of ministries submitted some of their payroll requests in advance of meeting a number of the requirements of the budget decree-including the requirement to provide the staffing numbers for the entire ministry before any salary funds would be released. A number of ministries provided salary requests for their Kabul staff, which the Ministry of Finance was legally unable to pay until the staff numbers across the country had been submitted. As the compliance with the budget decree has increased, the delay in salary payments has decreased.

That the delays can come down to under 20 days, as seen toward the end of SY1381, shows that the system, although manual and cumbersome, can be reasonably timely. However, the payment of salaries to civil servants remains one of the largest areas of corruption and discontent. The absence of a functioning banking system exacerbates this problem. Under the current system, upon receipt of correct documentation, the Treasury releases funds to a ministry to allow the ministry to pay their staff. However, while there is clear documentation showing that funds have left the Finance Ministry, there are frequent reports of the funds not being received by the individual civil servant who is entitled to receive the funds. This problem is not uniform across all ministries, but is a major issue. In some cases there have been tragic results, such as when former Ministry of Defense staff were fired upon in November 2003, killing one, as they protested about lack of payment of salaries, despite the salary funds having been transferred from the Ministry of Finance to the Ministry of Defense.

To address this, the Ministry of Finance has established a task force, reporting to the Deputy Minister (Finance) that is responsible for introducing individualized salary payments as a priority.

With the development over time of a functioning banking system particularly in the provinces, the payment of salaries will become a much simpler task, requiring few resources. However, in the interim, this critical task will occupy considerable time and resources.

\section{Financial Management System}

Progress has been made in laying the foundations for a financial management system within the Ministry of Finance (Treasury). In the first stage, with the assistance of a financial management agent (bearing point), a system for computerized check issuance began in Kabul in October 2002. This enabled "real-time" reporting of all expenditures processed through Kabul. By the start of SY1382 this accounting system had been augmented to allow for control of budget execution against budget allotments-again for all expenditures processed through Kabul. Recording of revenues is now also possible. 


\section{Figure 1. Delays in Salary Payments for the Provinces (excluding police)}

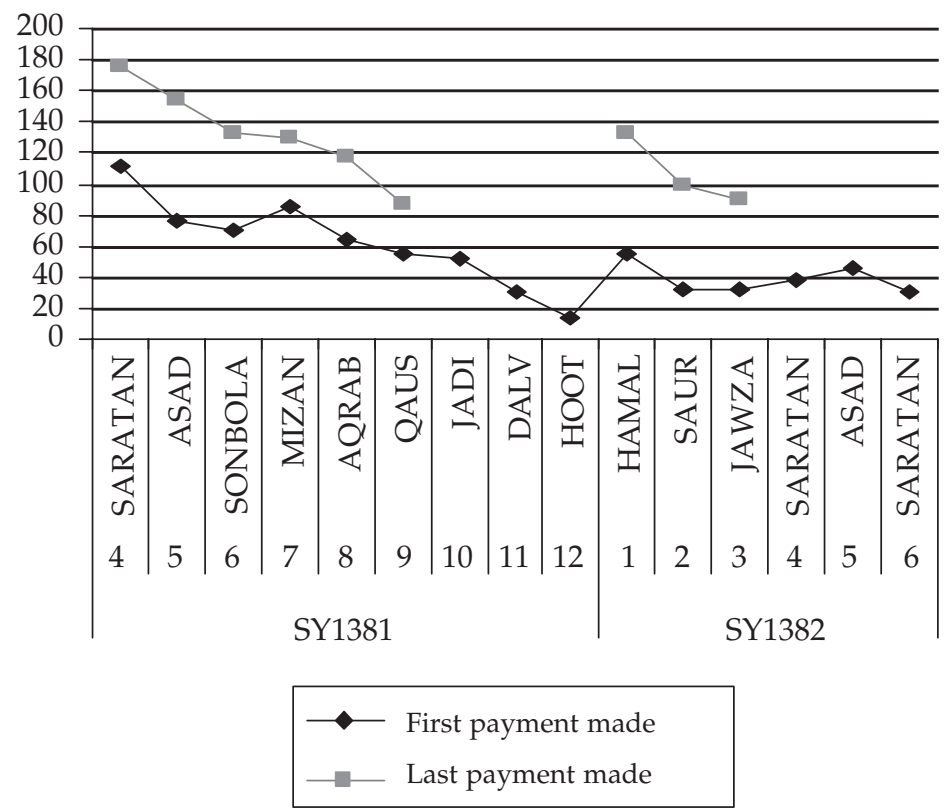

Source: PWC, ASI, and WB staff calculations from Evans and others (2004a).

Connectivity testing has also started with the aim of introducing the accounting system in one remote location.

\section{Procurement}

The existing procurement regulations require a decentralized approach to public procurement, with each entity handling its own procurement needs. However, later versions of the regulations refer to the possible designation by an entity to carry out centralized procurement of common-use items. Prior to its abolition, most of the procurement was undertaken through the Afghanistan Assistance Coordination Authority (AACA). A procurement advisor was recruited to work with the AACA in order to build procurement capacity while also ensuring short-term emergency procurement capacity was available. The procurement advisor was expected to assist in complex procurement, drawing from the line ministries for technical specifications. For "simple" procurement activities, the procurement advisor would provide guidance and support to the line 


\section{Box 3. Developments in Payroll Processing and Salary Payments}

In Kabul, the individualized salary payment (ISP) approach has moved along well-and the DAB is now making the final payments to civil servants in several Kabul ministries. ISP, in essence, is a simpler way of undertaking the "retail" part of the payroll process. It means that the DAB is contracted to pay individuals, receives a list of the individuals to be paid and the amounts due, and receives some percentage payment for managing the process. It cuts out the problem of distributing cash to the individual departments (removing the bonded trustees from the picture) and provides a more formal mechanism for distributing individual payments to civil servants-providing some check on ghost workers. Treasury concludes that there is not the capacity in the DAB to undertake ISP outside of Kabul - and thus, as yet, no attempt has been made to resolve the retail problems in the provinces and districts. Treasury is considering an approach in which the police payments for some pilot regions might be managed at the retail level-but the details of this are still under discussion.

ministries carrying out those tasks. No central entity has yet been designated within the government to undertake procurement, although the Ministries of Planning and Reconstruction have now been made responsible for the procurement function that previously came under AACA.

A legislative review has been undertaken and a draft procurement law and regulations have been prepared. Training has now been provided in procurement practices for a wide range of ministry counterparts. A draft procurement law establishes a procurement policy unit (PPU). The PPU is intended to assist the government in monitoring procurement activity, setting policy, and guiding the professional development of procurement officials. Consideration is currently being given to the location of the PPU.

\section{Audit}

The independence of the Auditor General has now been confirmed by presidential decree. An audit agent is providing capacity-building support to the Auditor General's office with the objective of assisting the Central Audit Office (CAO) to become an operational, independent, and effective supreme audit institution for Afghanistan that will provide the important link in accountability for public revenues and expenditures. The Auditor General has very recently signed off the audits of the World Bank Grants for SY1381 and has completed the audit of the ARTF for SY1381. 


\title{
Development Budget
}

\author{
Background
}

Under the Taliban and previous regimes, the Ministry of Planning prepared the development budget. During the budget preparation process, the Ministry of Finance indicated to the Ministry of Planning the resource envelope that was likely to be available for development projects from either domestic revenue or loans. The Ministry of Planning then, in consultation with line ministries, prepared a development budget.

Sometime early in the fiscal year, provincial departments submitted a request for specific capital projects to their respective ministries in Kabul. The line ministry reviewed these requests against the available development budget and informed the provincial departments which projects had been approved. The department then prepared detailed cost estimates that were submitted to the ministry in Kabul for its review and a subsequent specific allocation. The department then informed the respective districts, as appropriate. However, analysis of the projects presented as part of the development budget by the Ministry of Planning in 1381 suggests that the development budget had not been executed over the previous 10 to 20 years. In particular the majority of projects proposed for funding were begun in the 1970s or 1980s and had received no funding during the 1990s.

\section{Development Budget Preparation}

\section{Solar Year 1381}

The preparation of the development budget in 1381 comprised two major exercises: the preparation of the National Development Framework (NDF), which was presented at a major donor conference in Kabul in April 2002, and the presentation of a draft development budget that was presented, also at a major donor meeting in Kabul, in October 2002. The NDF provided general directions and priorities for development expenditures, organized into 12 National Development Programs (NDPs), under three broad pillars. Subsequently a number of national security programs were also added to the overall framework.

The draft development budget presented at the donor meeting in October was basically an attempt to capture the development expenditure that was either being undertaken or was planned. In this regard, it was a snapshot of the predominantly supply-driven activities of the donors, the UN agencies, and their implementing partners. While it did little more than catalog what people thought they were doing, it provided a critical starting point for the move toward a more demand-driven process. 


\section{Box 4. Issues in Managing the Development Budget}

Managing development expenditure in a post-conflict context is a complex issue that evolves over time. It is complex because of the combinations of sources of funds and responsibilities for execution. Donors channel their support for development expenditure through at least three different conduits: direct bilateral support, through grants to multilateral trust funds, and supporting concessional lending from development banks. Development expenditure can also be financed through domestic revenues. When the funds come from donors a range of different decisionmaking mechanisms for the allocation and the execution of the projects is available.

Budgets are traditionally about the planning, management, and control of expenditures. However, in the case of a development budget in a postconflict country, it is also about the coordination of aid resources. This causes considerable confusion among different parties, as the development budget must include items over which the government has no control. Adding to this confusion is the very limited understanding among many of the key actors that resources are limited. Spending ministries are generally met by a donor who wants to work in that donor's favorite area and asked if they want a project. The spending ministry has limited incentives and opportunities to make tradeoff with other projects and to consider the opportunity cost of the project.

The time horizon is also important. In an immediate post-conflict environment, the government is not in a position to articulate a cogent vision or an agreed set of plans. Coupled with the donors' goal of trying to disburse money very quickly-particularly on humanitarian needs-this can be characterized as a "supply-driven" approach to expenditure. Over time, the government builds the capacity to articulate what it considers to be the national priorities for development expenditure- - a "demanddriven" approach to development expenditure.

The challenge is to build a structure that serves the coordination role, but also introduces the concept of constraints. As an interim step, the goal for a post-conflict country is to have a development budget that operates like a wedding registry. That is, the development budget is made, mindful of the likely overall amount of assistance-which introduces the concepts of constraint and trade-off. Then the government's priority projects are listed and donors are invited to select the projects from the list that they will fund. In this way, over time, the development budget moves from little more than an aggregation of what donors are planning to do, into a demand-driven expenditure program.

In the early stages of a post-conflict situation, it is critical that all donorfinanced projects are included in the development budget to give a comprehensive picture of the development expenditure. However, over time, the ability of the government to lead the process and direct donors is 


\section{Box 4. (continued)}

enhanced. As the proportion of development projects that are financed by concessional lending rather than bilateral grants increases, it becomes important to start preparing a proper development budget for management and reporting purposes, which only includes expenditure that is controlled by the government, but that is complemented by a mediumterm public investment program funded by donors.

\section{Solar Year 1382}

The principles guiding the NDF and consultative group process provided the focus for the work of preparing the 1382 development budget and took concrete form in a call circular asking the 12 lead ministries associated with the National Development Programs to develop Public Investment Programs (PIPs) for each NDP, in consultation with cooperation partners. Tradeoffs are required as the Ministry of Finance sets some expenditure limits for each NDP, based on the overall level of resources expected to be available and assumed absorptive capacity of the sector. In discussing the development budget for 1382, the absorptive capacity argument was far more compelling on ministries than the overall resource ceiling argument. There was little understanding of the time lag between commencing planning for a major project and the expenditure of major resources.

Cabinet approved the National Development Budget on April 6, 2003. The total funding requirement was estimated at $\$ 1.7$ billion in 1382 , rising to over $\$ 2.6$ billion in 1383 and $\$ 3.6$ billion in 1384 as large projects get under way.

\section{Solar Year 1383}

Guidance for the 1383 development budget emphasizes that the 1383 Public Investment Program is to reflect more detailed information on needs, and enhancements in management and coordination mechanisms. The additional objective is that the operating and development budgets should be linked, with the operating budget including operating and maintenance expenditures for completed development projects, and providing sufficient capacity to assist in the implementation of development budget projects. It is partly on this basis that the responsibility for developing the development budget has been shifted to the Ministry of Finance. 


\section{Box 5. The National Development Framework}

Pillar 1: Human Capital and Social Protection

Refugee and IDP Return

Educational and vocational training

Priority-National primary health and education

Health and nutrition

Livelihoods and social protection

Priority -National solidarity program and emergency public works

Cultural heritage, media and sports

Pillar 2: Physical Infrastructure and Natural Resources

Transport

Priority-National transport (roads and airports)

Energy, mining, and telecommunications

Natural resource management

Priority-National water resource investment

Urban management

Priority-National urban infrastructure

\section{Pillar 3: Enabling Environment for Development}

Trade and investment

Public administration reform and economic management

Priority-National governance infrastructure

Justice

Security and law-and-order program

\section{Executing the Development Budget and Managing Development Expenditure}

Because donors (rather than the government) are providing the majority of financial support to the development budget and retain the contracting authority, monitoring execution of the development budget has been, and will continue to be, very complex. A number of programs such as the National Emergency Employment Program (NEEP) and National Solidarity Program (NSP) are funded through the budget, but implementation is largely contracted out to nongovernmental organizations (NGOs) with supervision provided by government ministries. This complexity is heightened by the different budget cycles between the donor government and Afghanistan and the lack of harmonization around key definitions such as "commitment" and "disbursement." 
Each NDP is supported by a sectoral coordination group. To stimulate effective coordination, a lead donor is designated to provide secretariat support for each program group in which relevant UN agencies and key NGOs also sit. Donors are requested to focus their financial support by contributing to three sectors only, to improve cohesion, and steer investment toward particular results and activities. Large donors are able to buy into additional sectors with a $\$ 30$ million contribution, if their commitment to their other three chosen sectors is at least that large. ${ }^{9}$ Discussion within the consultative groups is intended to help the ministry prioritize project areas within which donors may propose to fund and implement projects. Advisory groups on humanitarian issues, gender, environment, and human rights have also been established to allow cross-cutting issues to be integrated into national policy and budget preparation, in addition to working groups in key national security areas such as counter-narcotics and disarmament.

Execution of the development budget has been constrained by a variety of factors, including poor security conditions around the country, limited capacity in line ministries with respect to project and program management, procurement, and financial management. Figure 2 demonstrates the slow pace of execution. By September 2003, only \$223 million is recorded in the donor assistance database (DAD) as having been disbursed against an overall budget requirement of $\$ 1.7$ billion for 1382 .

The challenge in reporting on development expenditures is increased because the development budget includes projects that have no donor funding and, in some cases, will never be funded. Because any budget process is an exercise in political as well as economic analysis, on occasions the most appropriate way to deal with some ministry requests is simply to include them in the development budget, aware of the fact that the projects will not be funded. To address this issue, from 1383 onwards, projects will only be included in the development budget when they have attracted donor commitments of 50 percent or more of the total financing needs of the project, and a project document exists to allow implementation of the project. This will guarantee a greater degree of predictability and move the development budget away from being a "wish list" toward providing the best estimate of planned expenditure. Projects that are not funded will go onto a priority listing, and can be included in the development budget at the midyear review if funding has been secured.

\section{Major Challenges in the Development Budget}

Overall, significant progress has been made in the management of development expenditures. The major challenges in the development budget are not unique to Afghanistan-rather Afghanistan simply adds additional 


\section{Figure 2. Execution of the Development Budget-SY1382}

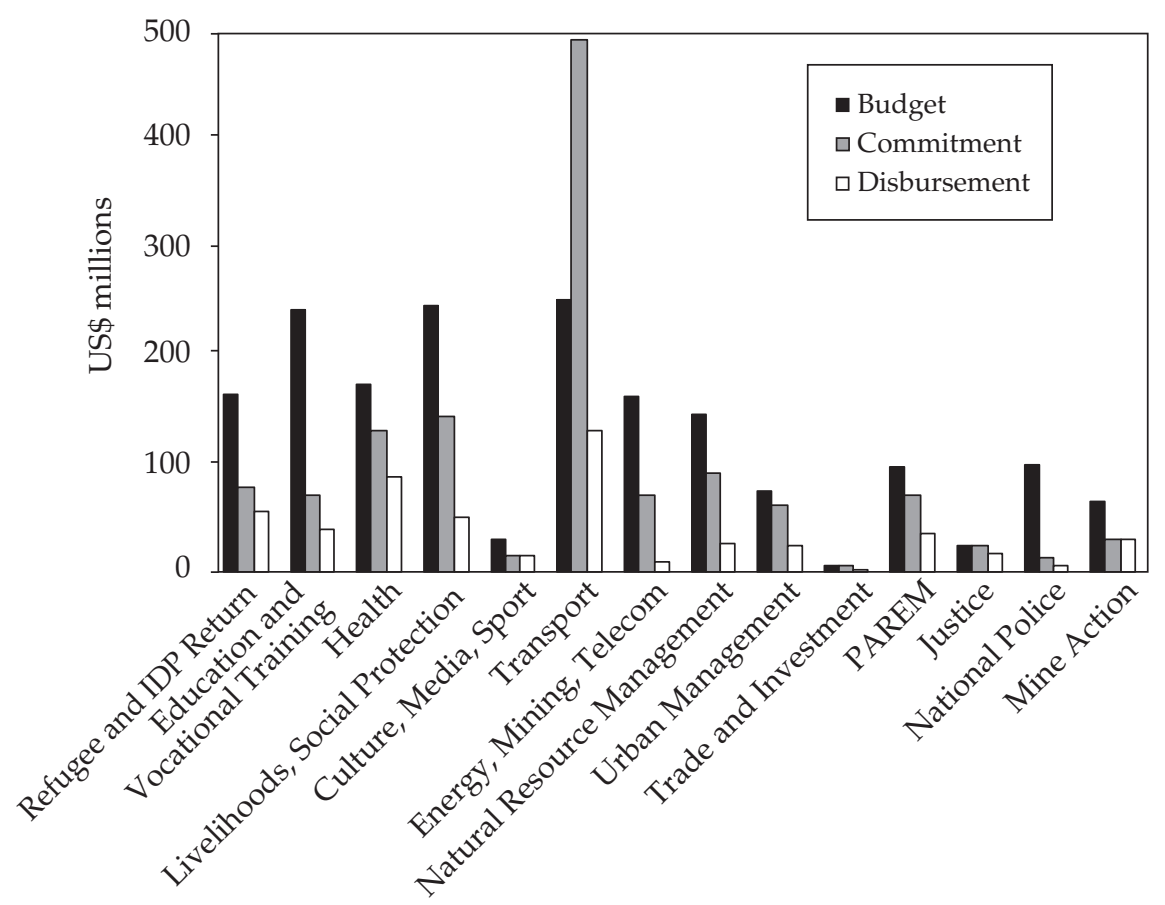

Source: Development Assistance Database cited in "Mid Term Budget Review" (2003).

weight to the arguments around a number of issues in the development industry. In particular, issues include: the pace of execution-relating to the chicken-and-egg problem that donors will fund completed projects, but until there is a clear understanding of the available resources, it is not clear what scale of project to design; the lag between commitment needs and disbursement needs, that is, often most or all of the funds must be available to begin the project, even though the funds will be disbursed over a multiyear framework; the need for donor funds to be available at the start of the budget year if they are to be disbursed during that year; and difficulties enforcing the discipline of the budget when both the line ministries and the donors who control the funds have incentives to ignore budget constraints.

Although a DAD has been established to assist with aid coordination and, increasingly, expenditure tracking, the difficulties in gaining accurate and timely information from donors remain a challenge. In general, analysis has remained at the level of donor commitments with some information 
on disbursement, but little is known about service delivery. The reporting that does exist remains highly aggregated and little analysis has yet been conducted regarding: (1) the long-term recurrent implications of the development budget, (2) the level of recurrent financing inherent within the development budget, (3) provincial allocation by NDB sector, (4) the geographic spread of the budget, and (5) analysis of the costs of execution through the $\mathrm{UN}$, NGO, or private sector.

\section{Conclusion}

Given the pressures and obstacles it faces, government has made significant progress. However, major challenges remain-particularly in the area of execution and implementation. In the case of revenue collection the major challenges revolve around the creation of a large taxpayer unit and also several medium-size tax offices in major economic centers-separate from the mustoufiats. In the case of expenditure, attention should be focused on the execution of the budget, including the timely payment of salaries across the entire country and the expansion of non-salary expenditure outside of Kabul. If progress in these areas over the coming year can be as rapid as the progress over the last two years, there is cause to be optimistic.

Improvements in the budget, the budget process, and the overall fiscal and financial management strategy of the government have resulted in more than an improved revenue and expenditure plan for the government. Since expenditure decisions were the first that the government was required to make, the strengthened budget process has played a major role in building the capacity of the government decision-making process. As the catalyst forcing the discussion of major policy issues, public finance is also playing a significant part in defining the structure of the government itself.

\section{Notes}

1. See, for example, "Securing Afghanistan's Future: Accomplishments and the Strategic Path Forward" (2004).

2. The Afghan financial year ended a week before the release of this volume, so 1382 final data are not available.

3. An interesting aside is that there was considerable international technical assistance focus on the structure of the tariff and attempting to bring it as close to best practice as possible. There was relatively little attention, in part because of lack of data, paid to the critical political-economy aspects of ensuring that the tariff would be agreed to-including both at a cabinet level and then in response to the organized opposition. For example, there was no distributional analysis of "winners and losers" from the tariff changes prepared. 
4. In Afghanistan the budget law refers to the ordinary budget, in contrast to the development budget. It is in some cases also referred to as the "operating budget" or somewhat inaccurately, the "recurrent budget."

5. There is considerable overlap between this section and Evans and others (2004a) as both draw on the same sources.

6. For example, performance targets should be included at an early stage, not because anybody expects them to be met but because it encourages a gradual change in mindset from patronage toward service delivery.

7. "No expenditures will be permitted by any ministry until allotments have been submitted to and agreed by the Ministry of Finance, including allotments authority distributed to provincial components of each ministry." (Section 4, 1382 Budget Decree.)

8. The proposed allotment process for 1383 is described in detail in the chapter on Budget Law Reform.

9. Government notes that donors can fund Afghan programs in three ways: (1) by direct contribution for designated purposes, to be administered by the Ministry of Finance; (2) through trust funds administered by international organizations before being channeled to the Ministry of Finance, for example, the Afghanistan Reconstruction Trust Fund; and (3) by direct support to private sector organizations to carry out government-identified priority projects. See Ministries of Planning Reconstruction and Finance (2002). 


\section{2 \\ Executing the Budget Outside of Kabul}

\section{The Problem}

Essentially since December 2001, provincial and district staff have been waiting to hear from Kabul. They understand the present centralized system and, broadly speaking, they support it. Some, but surprisingly few, provincial concerns are expressed about the top-down, Kabul-centered process for preparing the budget. Provincial departments are well accustomed to a planning and budgeting system in which they have virtually no involvement until they begin to receive their organizational charts with staffing levels, and their first-quarter funding allotments. They generally accept and expect a strong leadership role from the center.

However, there are indications that this "acceptance" is eroding. Concerns over the low level of non-salary allotment have been frequently voicedand more specifically the lack of cash in some provinces that has made it very difficult to spend the small allotment they receive. Provincial staff also note that at the same time, Kabul ministries have access to a non-salary operating budget that is disproportionately high compared to the relative number of staff.

The consequence, they note, is that they cannot do their jobs. Or, they are forced to be dependent on local commanders and other political elites who can provide funds to repair school windows or provide other nonsalary running costs, thereby further entrenching the power of the commanders. Ill-equipped, poorly paid, and ineffective provincial and district administrations serve only to undermine the presence of central government in the eyes of the population. Getting funds out to the provinces and districts needs to be the critical issue for the central government, not only

This chapter has been prepared by Anne Evans and Nick Manning, drawing extensively on Evans and others (2004a). It incorporates an earlier draft prepared for the workshop by Linda van Gelder and Ian Mackintosh of the World Bank. 
to support service delivery but also to shore up the weakening loyalties to Kabul.

A more significant issue has surfaced since the start of SY1382. The tashkeels that set the number of staffing positions and levels for all ministries, provincial departments, and districts have become disconnected from the takhsis (the budgetary allotment). This means that government units may have the authority to hire, but have inadequate budgetary allotment to pay their salaries. While it is not inherently wrong to have a funding allotment that is lower than the staffing establishment when faced with fiscal constraints, this is a radical departure from historical practice in Afghanistan, whereby provinces and districts were simply told how many staff they could hire. As a result, there is particular uncertainty regarding the authority of the provincial and district departments to hire staff.

Provincial staff hoped that some relief to their difficult working conditions and poor compensation would be forthcoming from Kabul quickly. But for various reasons, this has not happened. They comment, increasingly angrily, that the Kabul staff receive their salaries on time while they must wait for several months. Government has made considerable progress in this regard, but delays remain chronic.

The origins of the problem, and potential solutions, lie in allotment and expenditure arrangements for the non-salary and salary budgets.

\section{Provincial Allotments for Non-Salary Expenditures Are Generally Low}

Provincial involvement in budget preparation is marginal. In the past, particularly during the Soviet period, provinces did have some involvement in the budget preparation process. At some point before the beginning of the fiscal year, provincial departments would be asked by their ministries to develop a budget request for the upcoming budget year. Not only did departments routinely prepare a budget request, but also in some provinces the governor and heads of department would review the various department requests before they were submitted to the respective ministry. This group was sometimes referred to as the "budget board" or "administrative council." Even some districts reported that they used to prepare budget requests and review them collectively before they were submitted to the various provincial departments.

This practice no longer occurs. While some provincial Health and Education Departments reported receiving information requests to feed into the SY1382 budget process, in most cases these requests were limited to statistics on current resources rather than an assessment of needs.

To the extent that these information requests occur at all, this is the only point of involvement for the provinces in the preparation of the recurrent 
budget. The focal point for budget development is in the ministry head offices in Kabul. Staff in these central offices determine how much funding they will request from the Ministry of Finance, how it will be split between the central offices and the subnational departments, and how the subnational share will be split among different provinces. Once each ministry has completed its consolidated budget request, it is submitted to the Ministry of Finance (MoF).

Once the budget allocations for all ministries have been approved, each ministry prepares the quarterly budget allotments for each of its provincial departments, and sends this information to the provinces, usually well after the beginning of the quarter. How this allotment is determined is not clear, and uncertainties in the assignment of responsibilities to different levels of administration can only add to the challenges.

Once the provincial departments have received notification of their quarterly allotments, they are supposed to prepare similar quarterly allotments for their district offices, or subdepartments. These allotments should be provided to the district office of the ministry, and a copy should also be provided to the mustoufiat. The mustoufiat then would prepare a combined set of allotments for all the offices in a particular district, and then provide this information to the district finance office.

In reality, however, this generally does not happen. Just as provinces receive a relatively low share of non-salary expenditures, with some rare exceptions, provinces do not provide districts with any non-salary allocation. In some cases, particularly district health offices, some goods in kind are provided, such as hospital supplies, but no cash is transferred. More typically, districts simply do not receive any support beyond salaries. This is true as much in Kandahar, where there is significant overspending, as in revenue-poor Badakhshan or Faryab.

Analysis of the first-quarter budget allotments to the provinces for SY1382, in terms of the split between salary (personal emoluments) and non-salary expenditures, shows the total split across all ministries to be 77 percent for salaries compared to 23 percent for non-salary expenditures. However, the ministry-by-ministry split varies considerably.

Figure 3 examines the split of the total salary allotment for the first quarter of SY1382 between the center and the provinces, compared to the split of the total non-salary expenditures between the center and the provinces. These data show that considerably more of the non-salary allotment has been planned to be spent by the center. The split on average for non-salary expenditures is in fact 86 percent to the center versus 14 percent to the provinces, compared to a salary split of roughly 60 to 40 percent. In other words, the head offices in Kabul tend to keep a large share of the non-salary budget for themselves. It is possible that some expenditures attributed to the center are in fact provincial, but these data certainly argue for a careful review. 


\section{Figure 3. Distribution of SY1382 First-Quarter Allotments, Center versus Provinces}

Personal Emoluments

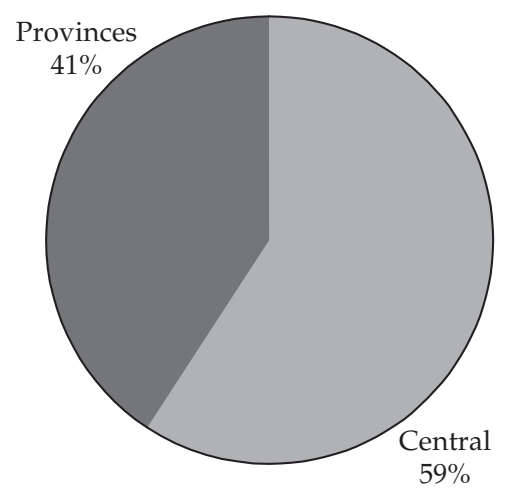

Non-Salary

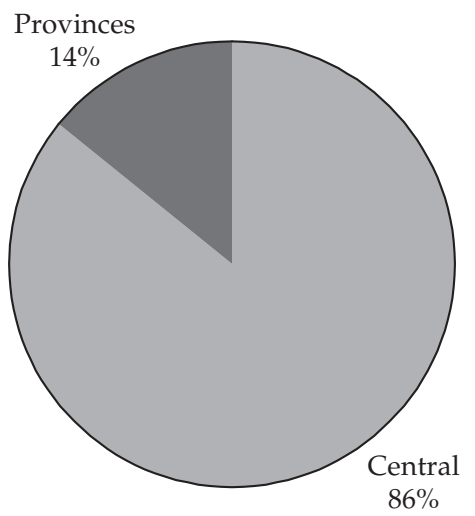

Source: Afghanistan Financial Management Information System (AFMIS), from Evans and others (2004a).

\section{Non-Salary Expenditures Are Even Lower Than the Allotments}

Table 1 shows the traditional practice for non-salary payments. The current reality is in flux. In SY1381, provinces that had no access to revenues, or who chose not to spend their revenues without permission from Kabul, were unable to make any non-salary expenditures until cash was sent late in the year. In some cases, where expenditures were considered unavoidable, some provinces made purchases on credit. At the start of SY1382, Kabul stipulated that no cash would be sent to provinces for non-salary purchases until expenditure reports were received. But for provinces with no access to revenues, this requirement effectively shut down access to their allocation. Some movement has now been made to forward some small portion of the non-salary takhsis to provinces in advance, but this remains a serious issue for provinces. For example, by the end of the first six months of SY1382, of the 755 departments operating in provinces, 426 (or 54 percent) had recorded only salary payments. In 13 provinces, salary payments accounted for more than 90 percent of total expenses.

Because most districts have had no access to non-salary expenditures for some time, there is little experience with this process in practice at the district level. In some instances a district-level request for a non-salary purchase is sent to the appropriate provincial department, which then follows the process 


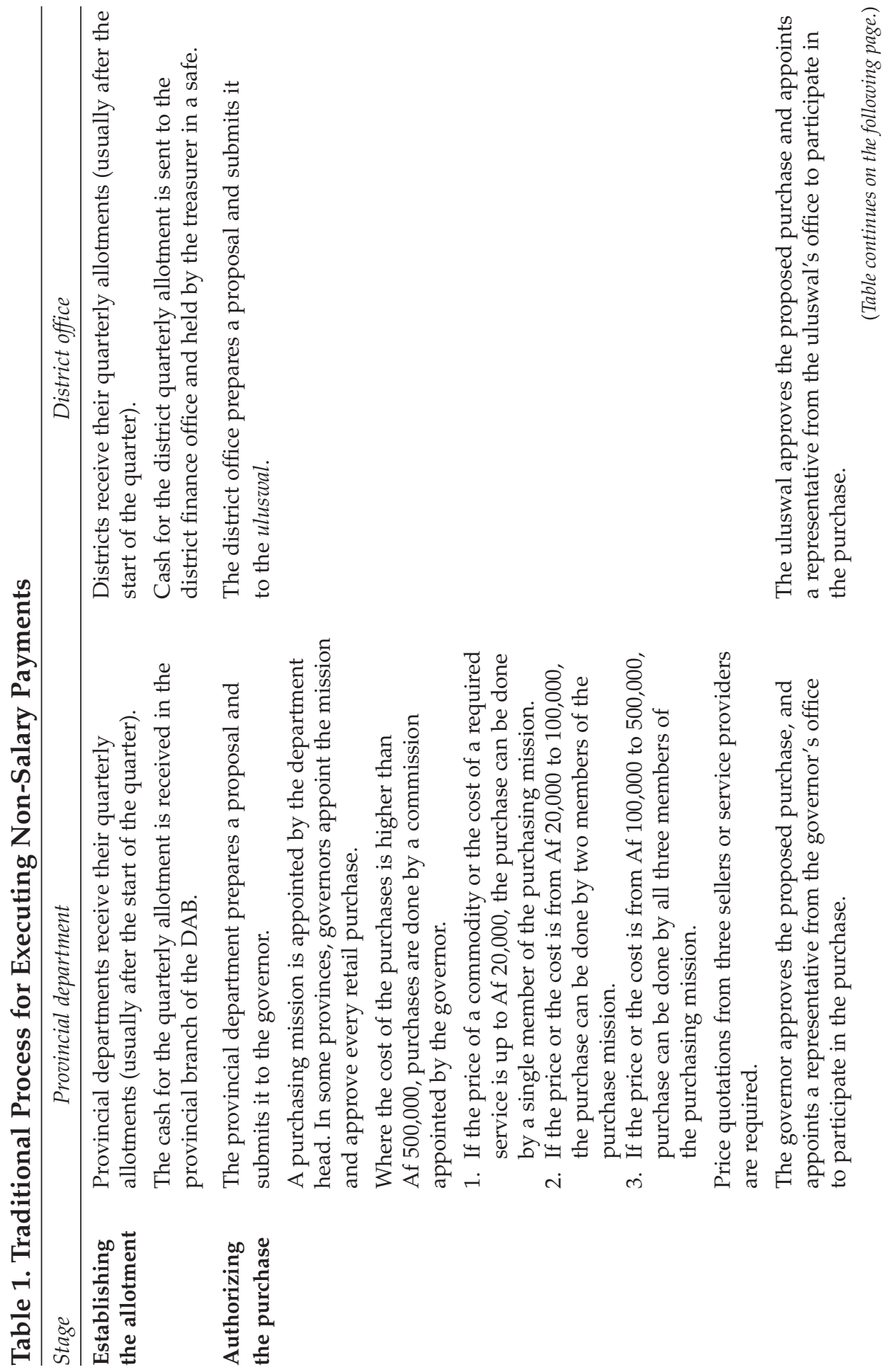




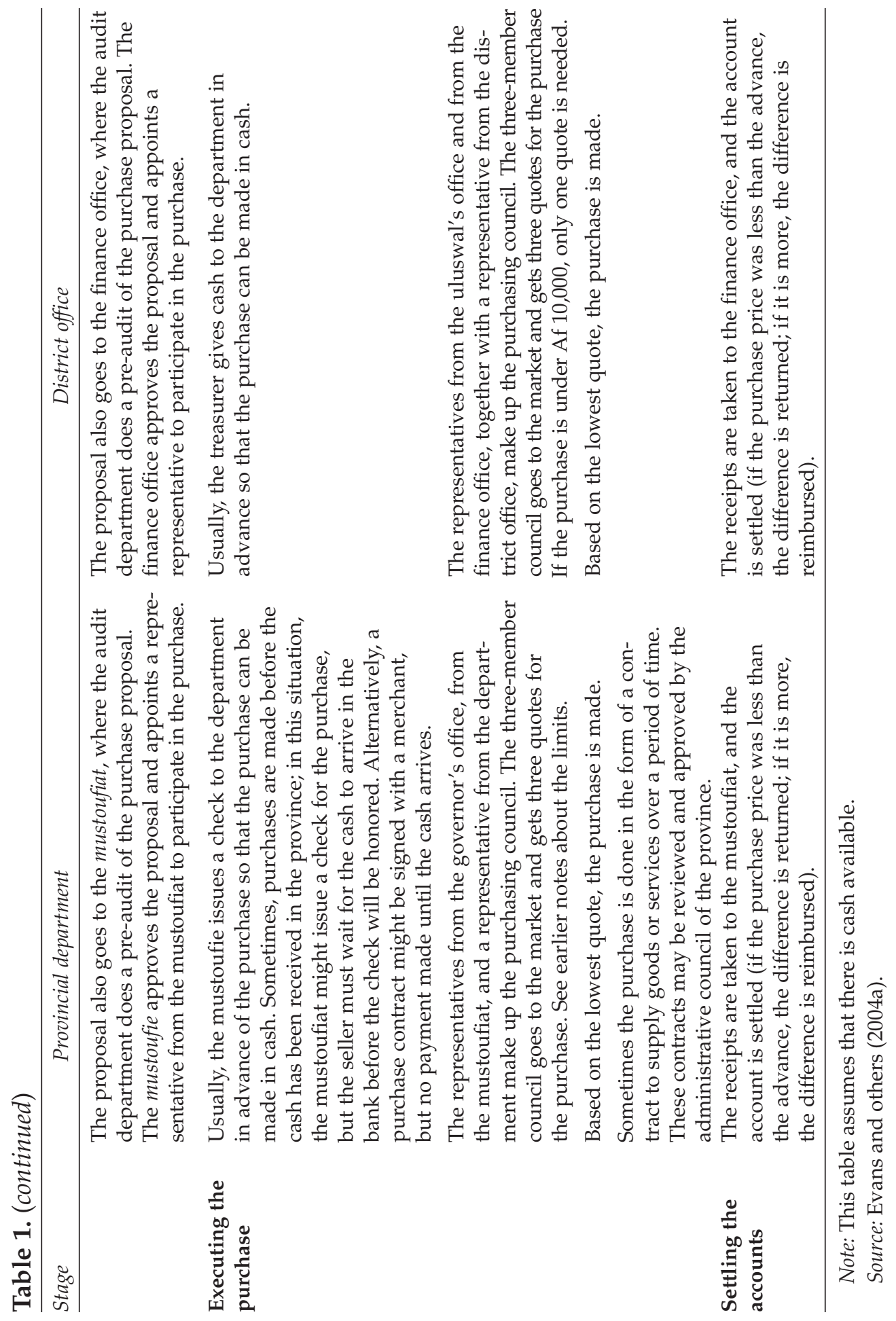


described above. Once the purchase is made, then the goods are sent to the district office. In this situation, the district finance office has no involvement in the process. Sometimes, goods are sent to the district without having made any request. For example, a shipment of firewood might arrive in the late fall, or a supply of paper may be received at the start of the year.

For those provinces that are largely or completely dependent on Kabul for cash, most 1381 expenditure went to salaries-in the case of Bamyan, as much as 95.1 percent. Only those provinces that had access to customs duties incurred substantial non-salary expenditures—and overspent their approved allocation.

Table 2 shows budget execution (expenditures as a percent of allotment), for six provinces. With the exception of Wardak, all provinces were significantly over budget last year. But the picture is dramatically different depending on access to revenues. For those provinces without significant revenues, the overspending is only on payroll. And to some degree this can be explained by the fact that, except for Wardak, provinces did not include United Nations Development Programme (UNDP) salary funding in their reported allotments. But for those with revenues, the big difference is on non-salary expenditures; the overspending on salaries is not out of line with the other provinces.

It is worth noting that table 2 does not speak to the appropriateness of the budget allocation for SY1381, but only the variation in execution. The SY1381 budget was based on very limited knowledge of needs and resource

\section{Table 2. SY1381 Budget Execution, by Expenditure Category}

\begin{tabular}{|c|c|c|c|c|c|c|}
\hline \multirow[b]{2}{*}{ Category } & \multicolumn{6}{|c|}{ Expenditures as percent of allotment } \\
\hline & Badakhshan & Bamyan & Faryab & Herat & Kandahar & Wardak \\
\hline $\begin{array}{l}\text { Personal } \\
\text { emoluments }\end{array}$ & 386 & 372 & 168 & 154 & 356 & 103 \\
\hline Services & 37 & - & 60 & 32,568 & 629 & 68 \\
\hline Tools and materials & 101 & - & 60 & 347 & 915 & 99 \\
\hline $\begin{array}{l}\text { Maintenance } \\
\text { and repairs }\end{array}$ & 75 & - & 78 & 7,283 & 3,730 & 65 \\
\hline $\begin{array}{r}\text { Land, structures, } \\
\text { and equipment }\end{array}$ & 79 & - & 85 & 2,110 & 3,299 & 67 \\
\hline $\begin{array}{l}\text { Subsidies, grants, } \\
\text { contributions, } \\
\text { and pensions }\end{array}$ & 74 & - & 80 & 18,936 & 22,798 & - \\
\hline $\begin{array}{l}\text { Subtotal, non-salary } \\
\text { expenditures }\end{array}$ & 86 & 62 & 64 & 3,654 & 2,714 & 83 \\
\hline Total & $327^{*}$ & 299 & 149 & 583 & 1,049 & 99 \\
\hline
\end{tabular}

* Total includes an "extraordinary" amount for reconstruction.

Source: Ministry of Finance (AFMIS), from Evans and others (2004a). 
availability; this has improved, but there is still much to be done, especially at the provincial level, as discussed earlier in this chapter. It may well be that much of the overspending was for "legitimate" government services. Nevertheless, dealing with this through the budget process is essential if improved equity across provinces is to be achieved.

\section{Cash Flow Restrictions Exacerbate Execution Problems}

Although all revenues are formally collected on behalf of the central government in Kabul, the system has traditionally sought to avoid the physical movement of cash, given the obvious transportation challenges. In essence, until recently provinces have spent cash that they have collected as revenue before seeking transfers from Kabul. (Some provinces in close proximity to Kabul, such as Wardak and Bamyan, have sent all revenues directly to Kabul.) Revenues from rural districts were placed in the provincial revenue account. When the collected revenues were insufficient to cover even non-salary expenses, the Treasury Presidency of the Ministry of Finance would make transfers for non-salary costs from the account of the Ministry of Finance to the mustoufiats on request. The payroll, however, was transferred on a quarterly basis. For other provinces-Herat and Kandahar being clear examples-no cash transfers from Kabul were made at all.

Transfers to Kabul would arise when revenues raised in a province were in excess of the approved budget. These amounts were supposed to be transferred to the government budget account at the end of the fiscal year, on the basis of the monthly income report provided by the mustoufiat to the Revenue Presidency in the Ministry of Finance. The Treasury Presidency in the MoF also has the authority to request that such surplus revenues be paid to the government account during the fiscal year. The reality, however, has been decidedly murky, and Kabul in effect has had to negotiate payment.

Traditionally, provinces and districts have held at least one expenditure account and one revenue account in the provincial DAB branch. Revenues collected locally would go into the revenue account, and expenditures were paid by check out of the expenditure account. Typically, provinces ran a positive balance in the expenditure account, and transferred funds from the revenue account as needed (or requested transfers from Kabul). More recently many provinces have had multiple accounts, both for revenues and for expenditures. But sound cash management principles argue for one treasury account for all operations. Reforms in the DAB are moving in this direction; in one of the first steps in this process, the government froze all existing bank accounts in the provinces on August 1, 2003, and replaced them with two accounts - one for revenue and one for expenditures. And, mustoufiats have no access to the funds in the revenue account without authorization from Kabul—-they can only make deposits. 
It appears that implementation of this change was less than smooth. When the accounts were frozen on August 1, mustoufiats were immediately denied access to the revenues sitting in local accounts, and were also left with limited information on how to operate the new accounts.

About 10 days after the accounts were frozen, small amounts were transferred into the expenditure accounts of each province-Af 1 million for small provinces and 2 million for large provinces, to be used for non-salary expenditures. The intent is to replenish these amounts on receipt of proper expenditure reports.

\section{Provincial Budget Allotments for Salary Expenditures Can Be Low}

The provincial department budgets contain two elements. In addition to the allotment or takhsis, they also contain a tashkeel—an organizational chart detailing all staffing positions and levels. So for the salary budget, effective constraint is the lower of the allotment and the tashkeel. Historically the allotment and the tashkeel were prepared in the Ministry of Finance and were automatically in step. The tashkeel was no more than a requirement about which sort of staff could be hired within the funding allowed for by the allotment. However, the tashkeels have become disconnected from the allotment. This has arisen because during the mujahidin period, the responsibility for preparing the tashkeel was moved out of Finance; now, the tashkeel is agreed to by joint committees of the respective line ministry and the Office of Administrative Affairs (OAA) in the President's Office, under the oversight of the vice president and head of the Civil Service Commission. This process provides the OAA with authority to agree to the tashkeel without the prior agreement of Finance as to the budgetary commitment that it represents.

The SY1382 budget decree sought to remedy this problem by requiring that ministries advise the Ministry of Finance of their proposed employment totals for their Kabul offices and provincial departments in advance of the financial year. ${ }^{1}$ However, while the Ministry of Finance did submit proposed caps to the cabinet, they were never approved. Ministries have now submitted numbers of posts by province; while they do conform to the overall ministry caps originally proposed by Finance (and the staffing budget), there is no guarantee that this consistency holds at the provincial department level.

This problem did not surface in SY1381, probably because in most cases tashkeels had not been updated, and provincial allotments were not enforced. But when first-quarter 1382 payrolls were being processed, the problem became all too apparent. The most dramatic example was from Education, where the approved tashkeel for Bamyan's education department 


\section{Box 6. Tashkeel versus Takhsis (Allotment)}

The point of coordination between the tashkeels and the takhsis or allotment is the line ministry. Finance does not seem to be in any position to enforce consistency. In the case of Education, it appears that the ministry has released tashkeels and allotments to provincial departments that are dramatically inconsistent. This might be (a) confusion, (b) part of their determined bid for expansion, and/or (c) the consequence of uncertainty about the numbers of teachers who are being paid by the Swedish Committee and other nongovernmental organizations (NGOs). (On the latter point, the positions for such teachers should not be included in the tashkeel, as the positions are not government posts. However, last year there was allegedly extensive double dipping with many teachers paid from both sources, so doubtless it has become very unclear. Everyone has had an interest in maintaining this particular confusion because, again allegedly, the additional teacher salaries have been shared within the departments as a general top-up.)

In one province, in 1382 the mustoufie-whether through political calculation or otherwise-was maximizing the damaging impact of the confusion: once it had become clear that the tashkeel and the allotment did not correspond, his strategy was to pay all teachers on a first come first served basis as the districts submitted their payrolls. Thus it was inevitable that he would run out of funds-and was predicting that he would not be able to pay teachers from the last two of six districts to submit their payrolls, representing a total of 50 schools.

Source: Evans and others (2004a).

was estimated to cost Af 7 million for the first quarter, but the salary allotment provided only Af 5 million. Add to this the fact that the allotment was only received toward the end of the quarter, the mustoufie was faced with denying pay to many hundreds of teachers.

\section{Challenges in the Payroll Process}

Provincial departments only have the authority to spend once the mustoufiat has officially received the quarterly allotment for each of the line departments. Once this is in place, the main activity regarding budget execution is the payroll.

As noted earlier, processing payrolls in Kabul is a new procedure introduced since the collapse of the Taliban. Previously, payrolls were consolidated and authorized for payment at the mustoufiat. The mustoufiat would receive the cash in respect of the quarterly allotment in advance, so that 
once the payroll had been verified, payment could proceed. Payroll processing has now been centralized and all information is sent to the Treasury Presidency in the Ministry of Finance in Kabul. The payroll, which is prepared by each line department using form M41, provides detailed information on each employee, including position, grade, salary, and attendance record. The department submits the payroll to the mustoufiat, and the provincial governor approves it. Once the governor's approval is received, the payroll is then sent to the Treasury Presidency in the Ministry of Finance in Kabul for payment.

The purpose of centralizing the payroll was ostensibly to audit its accuracy; however, no provincial staff interviewed had experienced any occasion where the payroll had been amended in any substantive way, although at times the forms would be rejected for a minor infraction. Provinces must wait for authorization from the Ministry of Finance before payment is received; reportedly, this can take up to a month while provincial staff wait in Kabul. Although payrolls may be submitted and paid monthly, most provinces have switched to submitting their payroll after every three months, mainly due to the time commitment required for each trip.

In the districts, the process is similar, but there are significant variations. The standard practice is for the payroll to be prepared by each district subdepartment, which then submits this information to the district finance office. The district finance office compiles the payroll information for all subdepartments, and gains the approval of the district administrator (uluswal). The district payroll is then sent to the provincial mustoufiat; once the governor has approved it, the payroll is sent on to the Treasury Presidency within the Ministry of Finance in Kabul. However, in many cases, the role of the district finance office is more limited; many subdepartments, particularly the larger ones, will bypass the finance office and summit their payroll directly to their respective provincial department, once the uluswal has approved it. In some provinces even individual schools will submit payrolls separately. Additionally, many districts only submit employee lists and attendance records, and the payroll forms are prepared by the provincial department. In the extreme case (Panjwayee district in Kandahar is an example), the district finance office has no expenditurerelated responsibilities whatsoever: it is not involved in any way with the payroll of other subdepartments, and only submits attendance records for its own staff. In this case, the only function of the finance office is to collect and submit revenues.

For many districts, and even some of the more remote provinces, the payroll process is subject to significant delays. The main reason that many provinces and districts have switched to a three-month cycle is the time it takes to prepare and submit the paperwork, wait for approval, and then collect the cash and distribute it. In some cases, especially where the roads 


\section{Box 7. Managing the Payroll in Remote Districts}

Perhaps one of the most extreme examples, the district of Darwaz is situated at the north end of Badakhshan bordering on Tajikistan. No roads connect it to the rest of Badakhshan; the only way to reach Faizabad (the provincial capital) directly is to walk, and this can take weeks. And Darwazt has no communications facilities.

To notify Darwaz that the cash for the payroll is ready to pick up, the mustoufie has to notify the Afghan embassy in Tajikistan, who sends someone to Darwaz with the message. Then, most likely, the persons who will collect the cash will cross over to Tajikistan, travel to the border point at Ishkeshim, and then travel down to Faizabad.

Source: Evans and others (2004a).

are poor or even nonexistent, the trip into the provincial capital can take a few days or even weeks, and this must be repeated once the cash is ready for pick up.

The delays arise from a series of obstacles at all stages of the payroll process. Table 3 shows the steps in the centralized payroll process, and flags the major problems. The major delays in the payments to provincial and district staff seem to arise at six points:

- Some provincial staff who are not confirmed in their position by their parent Kabul ministry are rejected from the payroll.

- The ministry provides the tashkeel late.

- The allotments are inconsistent with the tashkeel, at least at the provincial level.

- Provinces and districts are under the impression that they should only be preparing the M41s every quarter.

- The mustoufie must make what is often a laborious and time-consuming journey to take the payrolls to Kabul.

- Provinces report that many forms are repeatedly rejected by the Treasury Department for very minor reasons. There are extensive delays in the $\mathrm{DAB}$ moving the cash to the provincial branches.

As the table indicates, these delays will require systemic improvements at both the "wholesale" (authorization and transfer of cash) and "retail" (check preparation and cash payout) ends of the payroll process. 


\section{Policy Implications}

The budget execution problems for both salary and non-salary stem from similar difficulties - and ultimately can only be fully resolved if the system were to revert to the previous arrangement in place until some five years ago, in which advances were provided to the provinces on a quarterly basis. Some significant steps are being taken toward this goal for salary payments for provincial staff. The Treasury Presidency has concluded that outside of Kabul the primary problem in the short term is at the wholesale level. They have issued instructions for the decentralization of payroll processing from the start of 1383, and will be making advances to the provinces based on their approved tashkeels, sufficient for them to meet the monthly payroll. They will then replenish the advances based on actual expenditures. If the provinces do not report on their payroll within a short period, Treasury will recentralize the payroll process for that province.

However, even if they are successful, none of these developments would resolve the issues at the start of the wholesale phase concerning delays in staff being confirmed in position, delays in providing the tashkeel, or mismatch between the tashkeel and allotment. To resolve these problems, policy actions are needed. For example, in the case of staff appointments, where staff are not confirmed but continue to be employed, these staff should be automatically regarded as legitimate employees if notification is not received within two months of submitting the request. Similarly, policy actions are necessary to avoid delays in the issuing of tashkeels, by requiring that all Kabul ministries issue all tashkeels to all secondary and tertiary budget units before the start of the fiscal year.

On the non-salary side, the allotment issue can be resolved during budget preparation. The Ministry of Finance now officially approves the quarterly allotment of budget funds to the secondary budgetary units (SBUs) although to this point Finance does little more than register the allotments in the Afghan Financial Management Information System (AFMIS) database. Previously, once the funds were allotted to the primary budgetary units (PBUs), Finance had no further interest in how PBUs chose to allocate them between their provincial departments. Now, Finance has the opportunity to be involved in what might be regarded as a high level of detail concerning the relationship between the Kabul ministries and their provincial departments. ${ }^{2}$ The Ministry of Finance is using this leverage to increase the provincial allotments.

These policy actions can and will make the current fiscal arrangements work better. Nevertheless, these arrangements are highly centralized, even for a unitary state. There is additional scope to improve service delivery by modest delegation to provincial centers while keeping political accountability at the central level. In Afghanistan's case, such modest delegation 


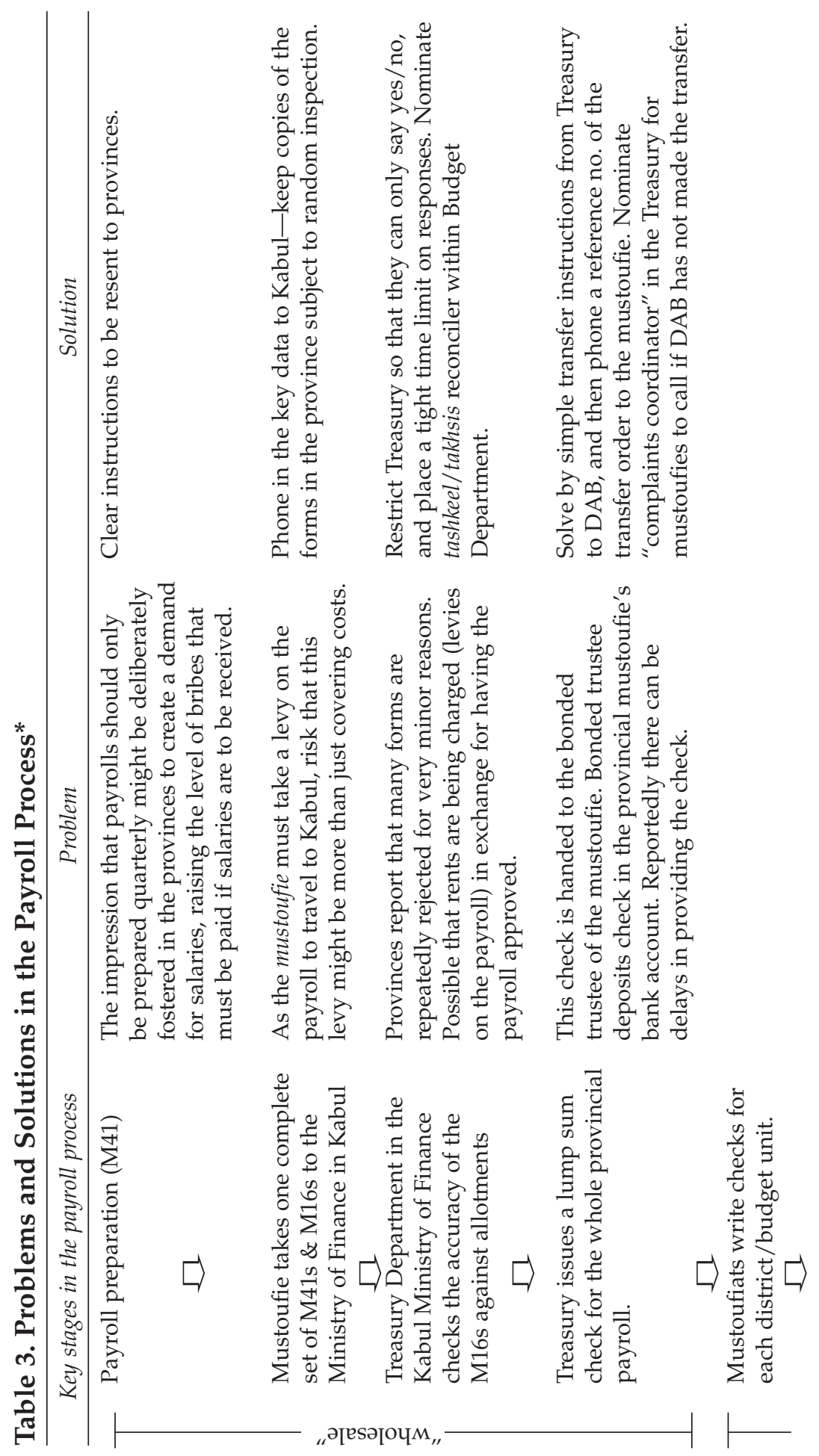




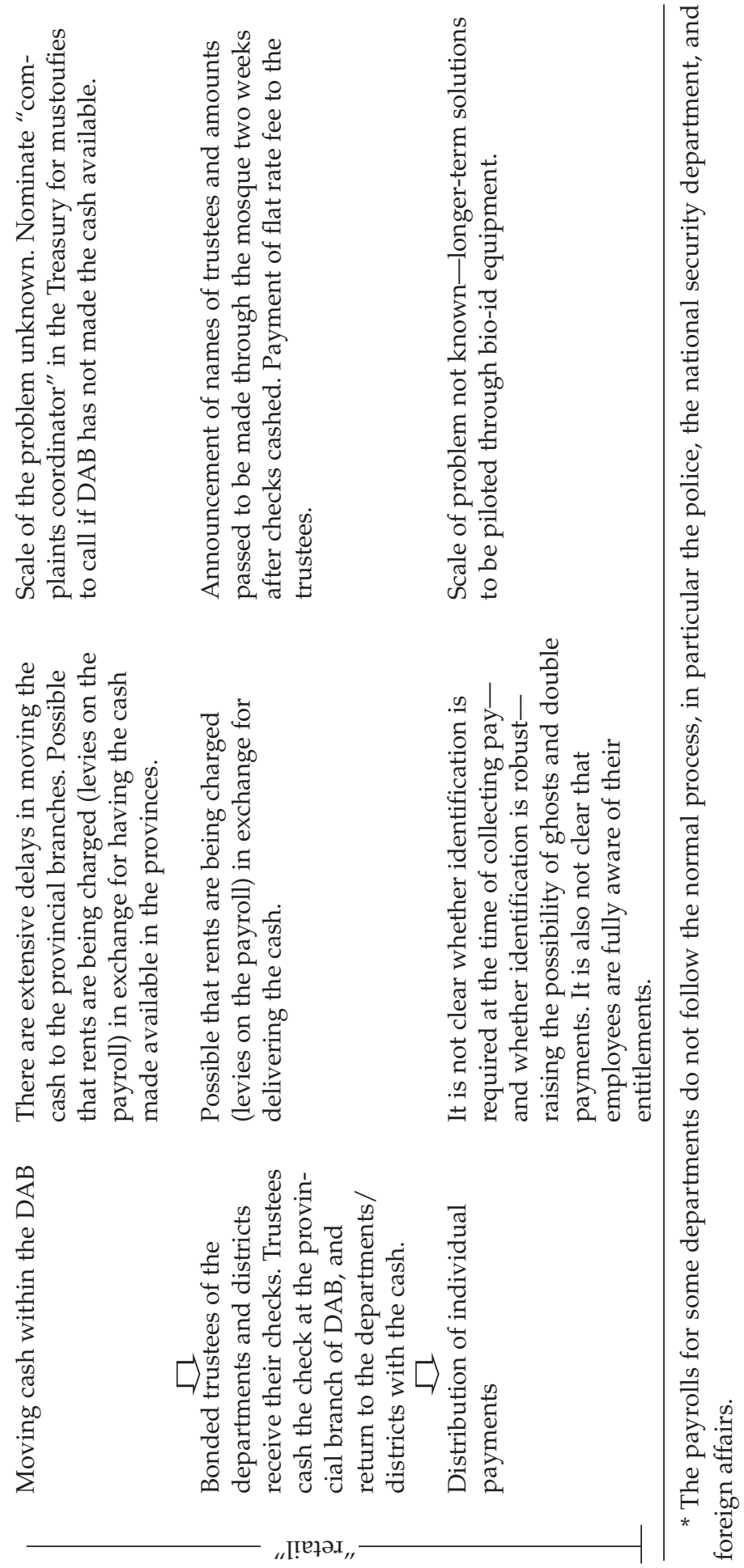




\section{Box 8. New Allotment Procedures for 1383}

Given the history of difficulties in executing the non-salary budget, the Ministry of Finance (MoF) introduced new allotment procedures for implementing the Ordinary Budget in 1383. Key points of the new allotment procedures are:

- Initial budget allotments for the first quarter will be issued automatically by the Ministry of Finance at the start of the financial year.

- Ministries are required to submit a plan for the apportionment of its ministry's annual budget between Kabul and the provinces at the start of the year (this information will also be used to issue allotments for the second, third, and fourth quarters). The information provided by the ministries on the planned apportionment of resources to provinces will be reviewed by the cabinet to ensure equitable distribution of resources to provinces.

- Allotments and suballotments for the second, third, and fourth quarters will be issued automatically at the start of each quarter. Ministries will not need to request the Ministry of Finance to issue allotments for each quarter.

- The requirement that ministries submit a spending report before the next allotment is issued in full will no longer apply.

- Ministries may review the proposed percentage distribution of the budget between quarters. The default allotment amount will be 25 percent of the total appropriation of the ministry in each quarter, and 25 percent of the total amount apportioned to the province in each quarter.

- In some circumstances, a ministry may require a higher or lower percentage of the annual budget to be allotted in a quarter. However, the total of all four quarterly allotments for all provinces must not exceed the total appropriation for the year.

- The annual appropriations for all items (except for code 50000: land, structures and equipment) will be issued to ministries in quarterly allotments as previously. To simplify the allotment process, the Ministry of Finance will issue the default allotment automatically to ensure that funds are available for spending at the start of the financial year. Ministries will not need to apply to the Budget Department to receive the default allotment.

- The default allotment amount will be 25 percent of the total appropriation per quarter. Allotments for land, structures, and equipment will require submission of a capital expenditure plan.

- The Ministry of Finance will also issue suballotments to each province automatically at the same time as the ministry allotment is issued. The province suballotment amount will be based on the amount that the ministry needs in each province during the year.

Because the 1383 budget was delayed, the MoF has issued default allotments based on expenditure in each location in 1382, as recorded in the AFMIS, with adjustments for decisions in the 1383 budget. These initial suballotments will be updated when ministries provide information on their actual spending plans in each province for 1383. 
should be conditional upon meeting some minimal level of administrative effort. Measures of administrative effort could include regular and accurate reporting of revenues and expenditures, evidence of basic financial control procedures, and a functioning provincial administrative council. With these in place, additional funds for reconstruction could be provided, as well as redecentralization of the payroll to the mustoufiat along with some modest increase in procurement authority. ${ }^{3}$

\section{Notes}

1. "Each ministry and Institution must present to the Ministry of Finance their proposed total employment specified by center and province before the beginning of the SY1382 financial year. After reviewing these proposals, the Ministry of Finance will recommend a comprehensive list of employment limits for each ministry by center and Province to the Council of Ministers during Hamal SY1382, and the Council of Ministers will approve the total employment limits for the ministries. Ministries and Organizations should not increase the number of their employees from the level in the month of Hoot, before the Council of Ministers review and approval." (Section 6, SY1382 Budget Decree.)

2. This has not centralized the process between the provincial and national level, as the previous decision makers were the central ministries.

3. For a more detailed discussion of conditional incentives, see Evans and others (2004b). 


\section{Case Studies in Post-Conflict Budgeting}

\section{Introduction}

Ideally, the government's budget is the process through which all the resources available to the state are allocated to their highest priority uses. The budget is also the tool through which the implementation of these decisions is monitored. This idealized world would be characterized by predictable resource flows, plentiful demographic and service level information, clear and enforced cabinet decisionmaking, and the bureaucracy staffed with competent and honest officials. In such a world, ministries would prepare their prioritized programs of actions, identifying service targets, and ensuring the balance between capital and current expenditure produced cost-effective production. The Finance Ministry would prepare the overall budget, framing the tradeoffs that the cabinet would need to make. Once agreed, the budget would transform from a resource allocation tool to a management tool. Ministries would take their resources, deliver services, and report against the service delivery targets provided in their budget submissions. Where service was below target, corrective management action would be taken to rectify problems. Perhaps most importantly in the postconflict context, in this idealized world resources from the international community would come in the form of direct budget support to finance the overall expenditure program.

In reality, the situation is quite different. Not only are resource flows very unpredictable, but the extent to which resources are actually under the control of the government is unclear and varies. Demographic information and actual expenditure from previous years are either scarce or poor. The public sector is staffed by underpaid officials with varying levels of competence and honesty. The political decision-making process is vir-

From papers prepared by Michael Carnahan (East Timor and overview), Gebreselassie Yosief Tesfamichael (Eritrea), and Bernard Myers, with Allister Moon, (Uganda). 
tually untried and the rules are either not established or not understood, and certainly rarely complied with.

A crosscutting complication in the overall resource allocation process in the post-conflict context is that donor governments provide the vast majority of resources for both development and reconstruction spending and also for the ongoing operations of the state. The challenge is to ensure that these resources are allocated to the national priorities. The easiest way to do this is to have resources provided to the government as direct budget support. However, donors are unlikely to do this immediately, if at all. There is a transition process from projects, through programs, to budget support-and individual donors will be able to make the transition to varying degrees.

- Project shopping list. Immediately at the end of the conflict, and often in the absence of either an expenditure plan or a national government, donors undertake emergency bilateral projects. These often take place under the auspices of a United Nations appeal, in which the projects identified by individual international agencies are aggregated together and marketed to donors. Donors choose the projects they like from the list.

- Prioritized project list. The next stage is when the government prepares a prioritized spending plan and donors are asked to fund projects that are on this plan. In this way the government's development plan begins to emerge from the shopping list.

- Sector program list. The third stage can involve the preparation of a coherent sectorwide approach rather than a list of priority projects within a sector. This program would include development and operational expenditure components and provide some information on the overall vision for the sector and the standard of service that is to be delivered. Donors would then be asked to fund the overall sectorwide program, rather than just picking up a single project within that program.

- Budget support. The final stage is when donors fund the budget rather than hypothecating their funds to a particular sector or a project within that sector.

The transition is facilitated by a changing definition of the budget. The ultimate goal is, of course, a unified recurrent and capital budget, embodying a medium-term fiscal framework, showing the implications of the policy choices that government has made. However, the early reality is so far removed from this that the initial classification is likely to be a one-year presentation of separate "operating" and "development" budgets, with the key distinction being that the former is funded from government's own resources and donor contributions of cash, while the latter is an attempt to 
discipline donors as they spend their money on projects that, even when there is government ownership, they would largely consider to be theirs, to be implemented according to their own donor procedures and timetables. Thus the starting point is, in reality, two separate budgets with two separate purposes.

In this context, this chapter provides a discussion of the progress that was made in East Timor in the area of fiscal planning and management in the first 18 months after independence. A number of lessons, possibly applicable more broadly, are also discussed. The second half of the chapter provides a discussion from two other post-conflict countries, Eritrea and Uganda, and focuses on the key elements that drove the reforms of the fiscal processes forward. These case studies offer no single or simple formula for success. However, they do offer examples of difficulties confronted and, if not completely overcome, at least diminished.

\section{Post-Conflict Budgeting in East Timor}

Following nearly a quarter of a century of organized, armed, and political resistance to Indonesian rule, the people of East Timor, a former Portuguese colony, voted overwhelmingly for independence in May 1999. After departing Indonesian militias destroyed much of the property in the country and forcefully resettled a large segment of the population, an international force (Interfet) was deployed to restore order. Soon thereafter, the United Nations Security Council passed Resolution 1272 establishing the United Nations Transitional Authority in East Timor (UNTAET) and vesting full executive, legislative, and judicial authority in the Special Representative of the Secretary General (SRSG). A peacekeeping force supported UNTAET militarily. Law and order, and general policing, were entrusted to an international civilian police force.

At the time UNTAET was created in late 1999, the National Council of Timorese Resistance (Conselho Nacional da Resistancia Timorense-CNRT), the opposition political umbrella group established in February 1998, had already set up a shadow political structure and had, in some areas of government, a shadow administration in place with significant policymaking capacity. In January 2000, the SRSG established a national consultative council comprised of 12 East Timorese and 4 senior international staff to provide advice on decrees that were enacted with the force of law. In July 2000, a cabinet of four East Timorese and four international staff was established as the executive branch of the government, while the National Consultative Council (NCC) composed of 36 selected East Timorese was created as a quasi-legislature. The NCC created a Central Fiscal Authority (CFA) as the foundation for a finance ministry. 
The social and economic situation facing the transitional authorities was grim both immediately and prospectively. Not only is much of the agricultural land of poor quality; the people have suffered from decades of low investment in the critical social sectors and in many cases from generations of chronic malnutrition. East Timor does not derive any strategic or commercial advantage from its geographical position. Its low population limits the size of its internal product market and therefore the possibility of exploiting scale economies in domestic production. Perhaps most tragically, a syndrome of welfare dependence, evolving through centuries of receiving fiscal transfers, has hampered the development of any sort of entrepreneurial culture. This was particularly the case during the period of Indonesian rule when substantial direct fiscal transfers came from Jakarta along with possibly even more substantial indirect transfers through cash-for-work schemes run by the military and by the private spending by the military. There are, however, considerable oil and gas reserves in the Timor Sea, good-quality fish stocks, and prospects for an eco-tourism industry. Translating these resources into high growth and poverty reduction, however, will require both good planning and dedicated implementation.

\section{Evolution of the Budget}

This section discusses the evolution of the budget over the period November 2000 to May 2001. It covers the preparation of the 2000-01 budget, the review of the 2000-01 budget, and the preparation of the 2001-02 budget.

FIRST STEPS: An immediate challenge was to develop a budget for the 2000-01 fiscal year, ${ }^{1}$ a process that lasted from March through June 2000 and that was hampered by lack of accurate information, shortage of qualified Timorese and international personnel, and confusion concerning the mandates of the international institutions involved. Those institutions included:

- The World Bank, which was the Trustee of the Trust Fund for East Timor $(\mathrm{TFET})^{2}$ and for planning the reconstruction and development of education, health, agriculture, and community empowerment programs.

- The Asian Development Bank, which had responsibility for planning the reconstruction and development of the infrastructure and microfinance sectors.

- The United Nations had overall responsibility to run the administration, UNTAET. It was also given the responsibility to oversee the "governance" sector. The UN was also tasked with control of the Consolidated Fund for East Timor (CFET) to meet the administrative costs of government and to strengthen the capacity of the Timorese elected government. 
In practice this meant that operating expenditure and capital expenditures associated with building the capacity of the government were funded out of the CFET.

- The International Monetary Fund (IMF), which had a macro oversight role, even though East Timor was neither a member nor an IMF program country.

The multiplicity of players and the confused mandates made the preparation of a meaningful budget very difficult. In particular, the rules surrounding what different sources of funding from trust funds could and could not be spent on, and the differing mental models of a number of participants added to the challenge. A further complexity was the inexperience in budgeting, financial planning, and management of a significant majority of the international staff placed in the UNTAET administration.

The vast majority of the preparation work was done by a very small handful of staff. As there were literally no domestic counterparts in place, the shortcomings of this approach were not as great as otherwise. ${ }^{3}$ At the end of May, after a six-week process, an (almost) agreed operating and development budget was ready for formal consideration by the NCC. The NCC accepted the development budget relatively rapidly, in part because of advance preparation work done by World Bank officials. The development budget projected expenditure of $\$ 70$ million under the Trust Fund for East Timor. It was expected that an additional $\$ 50$ million would be spent on bilateral projects implemented outside the government.

The debate around the operating budget was far more heated, reflecting the interests of several East Timorese NCC members in the staffing levels that were driving the budget. Tension around the operating budget was a consistent theme, in part because it was better understood, but mainly because the operating budget reflects the allocation of real resources that can be controlled. In contrast, the development budget during this period was more about coordinating donors and directing resources into specific projects or areas, while not having legal or financial control of these resources. A working group comprising CNRT officials and CFA staff subsequently convened to prepare a government staffing structure and a revised budget, based on this staffing structure and estimates of operations and maintenance expenditure needed to fund this level of staffing. The budget projected expenditure of $\$ 43$ million in operating expenditure and $\$ 15$ million in capital expenditure for government operations. This was presented and agreed at a very tense meeting of the NCC in early June 2000.

Formally, the budget became law on June 22, 2000, in East Timor when the SRSG issued Regulation 2000/21. This regulation legally constituted the entire East Timor Transitional Administration (ETTA) for the first time. It also legally established each department, if only as a budget entity legally 
entitled to receive funds. The budget paper was published and contained basic summary information of each of the major ETTA departments. For each department, information was included on funding from the CFET for both operating and capital expenditure. The World Bank provided information on reconstruction and development expenditure under the TFET in separate documentation.

These two budgets — operating and development—aimed to cover the majority of expenditure from domestic revenue and donor sources. ${ }^{4}$ However, the two budgets were developed separately and presented separately. There was not a complete consolidation of all the expenditures on a "combined sources" basis for East Timor. Due to the truncated preparation process and the nature of the UNTAET administration, a number of areas of expenditure were not included even though they would require funding later in the year. For example, it was deemed inappropriate to put in estimates in sensitive areas, such as defense or the legislature, until major policy decisions that would drive the costs in these areas were made. A notable area of resources not included in the budget papers was the funds made available to UNTAET through the United Nations Assessed Contribution Budget. This is the funding provided by member states to operate the UNTAET mission. During 2000-01 this was estimated at $\$ 600$ million— triple all other expenditure combined.

Budget REVIEW-October-November 2000: Under the circumstances of a truncated preparation process for the 2000-01 budget, the exclusion of a number of areas and the poor information available for planning expenditures, it was deemed prudent to revise the budget in November 2000. The three significant areas were defense, foreign representation, and the cost of the national legislature. In some cases, new spending was added to meet pressing political needs. ${ }^{5}$ The timing of the review also coincided with the inauguration of the National Council and it was considered appropriate to present the expenditure plan to this body for its approval.

A major development in the preparation of the revised budget was enhanced involvement of a subcommittee of the cabinet. In early October, the Minister of Finance submitted to the cabinet a proposed budget review. Following discussion of this submission, the cabinet agreed to establish a Budget Committee of the cabinet to review the budget, including identifying savings and areas previously excluded and preparing an unfunded priorities list.

At the end of the Budget Committee meeting, its recommendations were taken to the cabinet, which agreed to savings of $\$ 8.7$ million and the allocation of this funding to higher priority areas. The cabinet also agreed on an unfunded priorities list, which presented a short list of major development projects for which donor funding was sought.

From an administrative capacity building point of view, the Budget Committee work and the associated submission to the cabinet did far more 
than revise the budget. The submission included an additional 11 recommendations relating to issues that had come up during the budget review but had not been fully resolved. Among them were: problems in the power sector; civil service regulations that had been passed with no understanding of the fiscal impact; lack of coordination/overlap between the Civil Registration Project and the Electoral Project; and the lack of a budgeted, let alone funded, strategy for dealing with the demobilization of the Falantil (Timorese resistance forces). In highlighting these issues, the budget review contributed considerably to setting the policy agenda for the coming months and in this way the budget fulfilled a role as the key driver of policy.

The revised budget also reflected considerable work done in the months following July with the departments to have them focus on their program objectives, their performance measures, and the measurement strategy. This work enabled the inclusion of reasonable quality information in the revised budget to the point that its forward estimates were extended from one year to two.

The revised budget was the first major issue taken up by the new national council, where inexperience made its passage more difficult. Considerable time-much of it in both formal and informal meetings as well as public hearings-was devoted not just to instructing the new council members on legislative procedures, but also on developing the actual procedures for the first time. The budget provided a learning-by-doing opportunity for the council. A number of informal meetings with key members of the council were required to ensure a relatively smooth passage. One thing that made things easier from the CFA's perspective was that the council was asked to pass amendments to the budget, rather than a new budget. That is, if the council chose to reject the amendments, the budget agreed in June would simply continue to be executed.

Following the endorsement of the National Council, the revised budget became law in December 2000. The development program funded by the Trust Fund for East Timor was also extended concurrently as part of the budget review, and the council's endorsement of the TFET work program included providing authority to sign grant agreements over the period January to June 2001.

A published document-the East Timor Combined Sources Budget 2000-01-brought together the funding that was to be provided to each department from three different sources: CFET, TFET, and bilateral funding. However, while the information was provided on a "combined sources" basis, the planning for the use of the resources in each of these areas was still done on an individual basis. The combined sources budget, in short, was not a product of combined sources budgeting or any sort of sector-wide approach. 
PREPARING THE 2001-02 BUDGET: Building on the progress of the previous months, the preparation for the 2001-02 budget started in February 2001, with a four-week training course for East Timorese staff of the line departments and a one-week course for international staff. The coverage of the budget was substantially increased from 2000-01. Bilateral programs gained more prominence, and the resources from the assessed contribution budget that funded staff for the East Timor Transitional Administration were also included. Reflecting the coming elections, the budget negotiations also took on a more political tone.

The 2001-02 budget presented information on resources available in four categories: CFET (made up of direct donor contributions and domestic revenue), TFET (also funded by donors), direct donor projects, and the portion of the UN Assessed Contribution Budget that was used to fund ETTA activities. The inclusion of the assessed contribution funding caused controversy and unease in some areas, partly because international staff are relatively very expensive and having this information presented alongside the direct funding to the government was seen as potentially inflammatory. Specifically, the total CFET budget for government operations for 2001-02 was $\$ 65$ million, while the estimated cost of UN international staff working in the administration was $\$ 55$ million. However, in trying to introduce basic concepts of transparency, accountability, and effective budgeting, it was deemed essential to include this information. The extent to which its inclusion allowed for more effective decisionmaking by ETTA is contested-however, failing to include the information guaranteed that it would not be included in decisionmaking.

Both to build capacity and simplify the job of budget preparation, a major training exercise began with an intensive program for East Timorese staff working on budget issues. The month-long course, with classes and workshops lasting three hours each day, covered general introductory issues around fiscal and financial policies as well as detailed instruction in the budget preparation process. A four-day course of two to three hours per day was also provided to international staff.

A budget circular distributed at this time with full and detailed instructions called for a reasonably standard program-budget approach, with activities grouped together in programs. In each program, the services delivered by the program needed to be identified, as did the costs of operating the program on an ongoing basis, and the costs of any investments needed to increase the capacity at which the services can be delivered. The circular included forms to be filled out providing summary details on expenditures, by program and economic classification, and information on staffing. To facilitate the transition between a UN-run administration and an East Timorese-run administration, information was also sought on the reduction over the course of the year in international staff. Notwithstanding the light 
footprint approach, over 90 percent of the budget submissions argued for the same or a higher level of international staffing over the course of 2001-02.

The preparation of the budget submissions by the departments was very mixed. In some cases excellent work was undertaken. In the key social sectors of health and education, strong cooperation took place between the department, the CFA, the World Bank and other key donors, and the relevant missions. The approach of having a multidonor supervision and planning mission to coincide with the preparation of the budget was a tremendous step forward. For example, in the education sector the World Bank led a multidonor mission had as its focus to support the department to prepare the education budget submission. This submission was prepared on a "combined sources" basis. Activities that donors were planning were catalogued and included in the planning, along with development activities to be funded under the TFET; and the funds sought for the operation of these facilities were estimated, taking into account the level of investment and service to be provided. A similar process was followed in the health area. Considerable problems arose, however, in other areas, with little progress being achieved in either the budget preparation process or the budget submission itself.

After the preparation of the budget submissions, a series of budget hearings were held between the department and the CFA during mid-May. Following these hearings, the major decisions and areas of dispute were returned to the cabinet in late May. The cabinet took final decisions at the end of May and the proposed budget was sent to the National Council for endorsement.

To facilitate the passage of the budget through the National Council, a series of hearings were held at which the ministers or their deputies were invited to present their plans for 2001-02 and future years. These meetings became quite heated as potential opponents in the upcoming elections jockeyed for position with each other. While the hearings went some way to meeting the needs of the National Council, the difficulty in getting the budget agreed by the cabinet meant that, again, by the time the council formally received the budget, it had less than two weeks to consider it. As in the midyear budget review process, the CFA again had a number of bilateral meetings with key council stakeholders in advance of the meetings to facilitate the passage of the legislation. After considerable political wrangling, the budget was endorsed without amendment.

The appropriations regulation that was passed into law in June 2001 was accompanied by a number of changes to the tax laws and to the organic budget law that was adopted at the same time. As presented to donors at a conference in Canberra in mid-June, the 2001-02 budget was a very comprehensive document, covering total planned expenditure of just over \$300 million, comprising CFET (\$65 million); TFET (\$72 million); direct 
bilateral (\$112 million); and UN-assessed budget for international staff (\$55 million).

\section{Lessons from East Timor}

Setting the expenditure envelope

Not surprisingly, one of the most divisive issues in budget preparation in post-conflict settings is the size of the budget. In most countries, the size of the budget bears some relation to the ability to finance expenditure. Previous year revenues and access to capital markets provide a rough measure of probable total expenditure. However, when donor governments provide the bulk of revenue, the usual calculus becomes distorted.

A pragmatic resolution of the issue requires some awareness of the major differences in the mental models of different actors. The polar positions of this debate are:

- The "resource-based" approach-often attributed to the IMF. In this world view, the country should only budget on the basis of cash available- the operating budget should be set at a level at which there is certainty over funds availability.

- The "needs-based" approach—more likely to be found in the UN and other multilaterals and bilaterals. In this model, the budget should outline what the country needs and the international community should be encouraged to provide the funds needed for the expenditure program.

The resource-based approach provides greater predictability and certainty, but may reduce the resources coming to the country, as the budget has less use as an advocacy tool. The needs-based approach has more use as an advocacy tool, but does not give the administration any certainty or predictability of funding. Given needs-based appeals are usually significantly underfunded, the prioritization is compromised as donors can choose from among the many needs what they will fund, rather than being directed to the country's highest needs.

The setting of the budget envelope owed much more to art and politics than science. The following factors were taken into account with differing emphasis at different times:

- Long-term fiscal sustainability. Can the level of operating expenditure be financed domestically in the medium term, and will there be funds to operate and maintain?

- Setting stretch targets for donors, but interpreting their promises conservatively. It is politically easier to increase spending than decrease it. In this regard, a critical determinant is that the one thing that donor gov- 
ernments fear most is providing budget support into the medium term, thus being stuck providing it while other countries stop.

- Crude estimations of the long-term level of revenue generating capacity. The rule of thumb often applied is 15 percent of the medium-term legal level of GDP. Future oil and gas revenues that the country may earn are of course an added complication.

\section{Tactical Lessons}

THE MAJOR BATTLES ARE AROUND THE RECURRENT BUDGET: Governments agree on development or capital budgets relatively rapidly, because political leaders see them as abstractions. Even though the expenditures are critical, the money is not as tangible. In contrast, the operating budget involves real opportunities for patronage through the provision of either employment or contracts funded by real money. Moreover, delays in implementing the development budget simply push a project into the following year, while delays in implementing the operating budget mean that teachers or police do not get paid.

FOCUS ON BUDGET EXECUTION: While most departments complained that their resources were low, East Timor was in the very unusual position of having six months of budgetary resources in the bank at the start of the year. This is not uncommon in post-conflict countries, whose budgets are partly funded through multilateral trust funds, in contrast to most countries that will not even have one month of revenue in the bank and will be relying on revenue collections in the month to meet obligations that month. The problem is the inability of the departments to spend their budgets. In many ways this is not surprising. A budget submission that is not supported by an action plan is nothing more than a collection of numbers. Weak capacity in line ministries to plan to spend the budget automatically generates problems in spending it. The lack of ability to execute the budget and deliver needed services reflects a shortage of management capacity, not a shortage of money.

MAINTAIN AN UNFUNDED PRIORITIES LIST: The inclusion of an unfunded priorities list in the budget serves two main purposes. First it introduces a sense of priority into the bilateral programs of donors and highlights to the leadership that the bilateral funding is a scarce resource-not a bonus or extrabudgetary reward - so that if they wish to direct resources in their country, they need to exercise some control over the allocation of bilateral spending.

It also provides a place that some of the less economically defensible projects can be located. Projects that are a lot dearer to ministers' hearts 
than they are ever likely to be to donor checkbooks can be placed on this list, with the Ministry of Finance secure in the knowledge that no donor would fund it. This safety valve can stop particular ministers from insisting that the project be in the budget.

USE SIMPLE PERFORMANCE MEASURES: There has been criticism about the introduction of performance measures or concepts like program budgeting at an early stage with a nascent administration. However, the purpose of introducing these measures is to introduce major cultural change within poorly performing bureaucracies. If bureaucrats in a new administration simply think that the government should be performing or delivering a service to the public, then something has been achieved.

\section{Managing Expectations around Pledged Amounts}

The international community pledged $\$ 521$ million to East Timor. Unfortunately, the very interested national stakeholders assume that this amount is available in cash for the country to spend. Even those who are familiar with development practices are confused by numbers that are unclear and loosely constructed. They include pledges of varying durations-particularly mixing single- and multiyear pledges-and they include both grants and concessional credits. Confusion is added when the practices and conditions that donor countries impose on the use of the assistance are included. There is an unhelpful political imperative on the part of the international development community to announce a large figure and to claim success.

\section{Post-Conflict Budgeting in Eritrea}

\section{Context}

Liberated in 1991, Eritrea was a physical and economic ruin. A 30-year war had turned more than a quarter of the population into refugees or internally displaced persons, many of them disabled. Recurrent drought had devastated agriculture. The treasury was empty; the Central Bank had no foreign exchange reserves. Most of the managerial and technical staff within the bureaucracy and the state-enterprise sector had left with the defeated Ethiopian army. Corruption was endemic. Almost every field of endeavor lacked trained professionals, and other than minimal nongovernmental organization (NGO) humanitarian assistance, the new country received no external aid for its first three years.

Progress since then can be credited to many factors. Among them was the high level of optimism of the newly independent people, an exemplary level of cohesion and unity among the nine nationalities, and a healthy 
legacy—broad popular participation, decentralized decisionmaking, and extensive practice in self-reliance-from the liberation struggle. Another critical ingredient was the contribution of Eritreans living abroad-the diaspora-in both financial and human resources. The Ministry of Finance, for instance, recruited more than 50 experienced, highly trained Eritreans living in Ethiopia to staff various government ministries.

Even with the emphasis on self-reliance and the help provided by Eritrean professionals returning from abroad, the government required extensive technical assistance to advance its ambitious programs of economic and social reform. With the Ministry of Finance and Development playing a central, coordinating role in managing public finances and overseeing financial services, the government took the position that partnership-not donor/recipient relations-was to govern the use of aid and technical assistance (TA). Along with national ownership of policies and programs and national determination of the timing, sequencing, and pacing of reforms, it insisted that technical assistance and/or aid-to be effective- had to build capacity and obviate the need for further aid. While this approach gets universal applause in theory, the Eritrean Government was willing to make hard choices to ensure that the model was put into actual practice. Thus, when the Paris Club donors insisted, in 1994, on making a structural adjustment program a condition for substantive budget support funds, the government chose instead to maintain its freedom of action-its ownership of policies and programs and of the content and pace of its reforms.

\section{Selectivity in Technical Assistance}

When aid did begin to flow, it brought significant, if highly selective, technical assistance programs and inputs, including a mix of short- and longterm advisors none of whom served in a line function. One of the major components of the $\$ 130$ million Recovery and Reconstruction Program that the Ministry of Finance (MoF) managed was capacity-building economic and financial management. This component channeled substantial technical assistance to the MoF, the National Bank, the Commercial Bank, and the Office of the Auditor General in the form of long- and short-term experts, training in and outside of the country, studies, and equipment.

The government suggested that, particularly for long-term consultants, it would improve effectiveness if the TA providers would submit a short list of candidates to the relevant government department rather than making the final selection themselves. TA, particularly long term, was always expected to have a dual purpose: delivery of service and training. There were, however, sometimes problems with the training component, usually due to lack of availability of national counterparts. 
Indeed, the lack of adequately trained and experienced professionals with exposure to policy analysis, formulation execution, and review was one of the biggest constraints in economic management and in practically all other areas of public administration. Fortunately, Eritrea-like Afghanistan-had a huge diaspora pool from which to draw the requisite skills and experience. Active recruitment of professionals and provision of the necessary incentives in terms of housing and pay on top of the individuals' own sense of duty went a long way toward meeting the needs for adequate compensation. To deal with continuing human resource shortages, the government stopped the proliferation of new institutions and departments and instituted a long-term, capacity-building program to send 500 experts abroad for up to five years of formal, postgraduate studies, filling their posts with outsiders for the interim.

While there was pressure from external partners to set up independent implementation mechanisms, or project management units (PMUs), as a traditional mode of guaranteeing better execution of externally financed projects, the government resisted doing so. Instead, it set up one strong PMU in the Ministry of Finance and Development to become a training, support, and implementation center and set about strengthening the sectoral units. Lack of knowledge of the mandate, resources, modalities, procedures, regulations, expertise, flexibility, and institutional culture of the multilateral and bilateral financial and aid organizations was a problem that required immediate attention.

\section{Strong Leadership from the Ministry of Finance}

Decentralization, particularly a certain degree of fiscal devolution, occurred more or less spontaneously at an early stage. The result was an incongruous reappearance of "fiefdoms" created by regions imposing customs, duties, and other taxes on movement of goods and services in order to mobilize development funds. A quick stop was put to this; and the practice was replaced by a clearly defined, highly restrictive set of local revenue-raising modalities. In addition, the government started transferring equal annual grants to all the administrative regions to invest in their own set of priorities.

As the primary government agency of change, the MoF helped set the priorities and sequencing of a series of reforms over the first six postliberation months: a new tax regime that significantly reduced rates across the board, the removal of price controls, the dismantling of the centralized marketing system, the return of all formally nationalized rental houses to their original private owners, the removal of all restrictions on private sector engagement in foreign trade, the relaxation of foreign exchange controls, and the promulgation of a new investment code. 
In a post-conflict situation, particularly when the conflict has been as protracted as it had been in Eritrea, the size and role of the public sector and level of external engagement are inordinately high, creating extraordinary demands on national economic management. In Eritrea, this complex challenge was met by establishing a strong MoF as the lead agency in economic management endowed with the full range of planning, finance, and aid coordination functions. Although this pragmatic and effective arrangement facilitated the deployment of scarce human resources, it may also have resulted in an overcentralization of decisionmaking.

The immediate post-conflict period in Eritrea proved an excellent window of opportunity for change, a period when the MoF reform program involved such bold initiatives as radically revising the tax structure and tax administration, introducing a comprehensive budget system, and reviewing implementation of public programs and policies. Simultaneously, technical assistance supported long-run programs to introduce state-of-the-art systems in customs, internal revenue, and other departments.

The Eritrean experience underlines the point that the immediate post-conflict period is a critical moment that can have far-reaching impact in setting the tone for the subsequent era. It establishes the quality or nature of the relationship between the people and their government, shaping popular attitudes, either motivating them to be enthusiastic participants in the management and transformation of their national life or relegating them to the role of disillusioned and disgruntled bystanders.

\section{Post-Conflict Budgeting in Uganda}

\section{Context}

Following the collapse of donor support and an attendant major fiscal crisis, drastic action in early 1992 by the Government of Uganda produced what some have described as one of the most dramatic turnarounds of a Ministry of Finance in Africa. The reform built from an early and unusual presidential action: the merger of the formerly dominant Ministry of Planning into the Ministry of Finance. Critically for the subsequent reforms, a very effective and dynamic permanent secretary, previously in Planning, took over the main policy position at Finance. This official, almost by force of will, skillfully managed the process of reform, including the strategic decisions in using external technical assistance and building effective coalitions with other institutions.

Proceeding on two fronts-the institution of short-term cash management controls and a reformulation of budget preparation to engage political decisionmakers earlier and more aggressively - the new MoF pushed through the idea of the budget system as the main instrument of fiscal 
policy. Around that concept, a new group reviewed fiscal decisions to see how they supported macroeconomic policy and make needed adjustments. A willingness to adjust the macro position if circumstances dictated headed off the kind of short-sighted cash management witnessed in other countries, but budget systems that did not receive the necessary attention resulted in weak commitment control procedures that contributed to a concealing of liabilities.

\section{Using the Budget to Drive Reforms}

Implementing the new status accorded budget preparation, a Budget Framework Paper requiring cabinet-level approval clearly framed the economic tradeoffs and provided some MoF recommendations. The paper forced the entire cabinet to assume collective responsibility, when, for example, MoF opposed a line ministry's program or projects. MoF did not always win those contests, but their airing in the cabinet, with the President as final arbiter, made it clear to everyone that Finance would not carry the weight of economic policy alone. Additionally, the annual budget process was successfully turned into a substantive discussion about the role of external financing, requiring that the government spell out its policy intentions and assumptions about external financing. It then placed the responsibility upon its cooperating partners to indicate whether those financing assumptions were accurate. In general, this specificity in terms of government policy and programs helped make the budget process part of a public review process.

\section{Selectivity in Technical Assistance}

The effective use of foreign technical assistance played a significant part in advancing the reforms, not least because the $\mathrm{MoF}^{\prime}$ s new permanent secretary had been accustomed to working with foreign TA and was very comfortable with it. He cultivated an environment of active give-and-take with TA experts, one of whom was appointed Chief Economic Advisor to the $\mathrm{MoF}$ while others served in line positions. As a result, coordination of TAincluding guidance on future work priorities-improved and the amount of contradictory advice diminished as new donors were steered toward the priority needs of the ministry. Despite some outsiders' criticism that the ministry was being taken over by the foreigners, the permanent secretary essentially gave priority to getting the work done-even if it meant more TA, and relations between staff and TA were generally good. It helped that each expert was assigned to a specific department that had an output to generate; this created a healthy rivalry among the departments. It also helped that as donors became impressed with the progress of reforms, they 
discreetly provided salary supplements to all $120 \mathrm{MoF}$ staff with the assistance fixed to the work program and phased out as the salaries rose.

\section{Factors Affecting Reform}

Summarizing Uganda's experience, some of the success factors included:

- Balance between the short term and the long term, getting immediate macroeconomic policy right without neglecting longer-term strategies.

- The presence of four or five outstanding people, critical to the task, the permanent secretary, in particular.

- A working culture open to seeking advice from outside, willing to review the advice critically and able to utilize TA in departments where they were seen as team players.

\section{Notes}

1. The East Timor fiscal year runs from July 1 to June 30.

2. The TFET was a multilateral trust fund designed to provide funds for reconstruction and development.

3. During this budget preparation, none of the staff to be funded under the 2000-01 budget had been recruited.

4. As noted in the introduction, the distinction between an operating budget that is funded from government's own resources, and a development budget that is an attempt to discipline donors as they spend their resources, is less than idealbut is a necessary short-term stage.

5. For example, the proposed ferry service linking the enclave in Oecussi with the rest of East Timor. 


\section{PART II \\ Current Priorities}





\section{4 \\ Priorities for Reform in Post-Conflict Finance Ministries}

\section{Introduction}

The influence and functions of Ministries of Finance ${ }^{1}$ vary from country to country, depending on the role and structure of the state, the level of economic development, and frequently the political economy of government. Most finance ministries in modern, market economies place a premium on effective macroeconomic management and setting standards for government financial operations. Many advanced countries (for example, New Zealand, Scandinavia, the United Kingdom, and the United States,) also use the Ministry of Finance (MoF) to support performance-based budgeting, a process requiring many years to implement. Under such systems, the MoFs perform largely policy-related functions, leaving the operational aspects of financial management and accounting to the spending agencies at the central or subnational levels.

Afghanistan, like most developing countries, must deal with an intermediate stage, where the MoF must fulfill both policymaking and some operational functions. In the post-conflict stage, it is advisable for the Afghan MoF to focus on consolidating its basic functions and to opt for a simple organizational structure that delivers financial management services with the limited skilled-manpower resources available. In line with other developing countries, the preferred model is for an integrated MoF, delivering all the government financial management services-

An initial version of this chapter was prepared in August 2003 by Ehtisham Ahmad, Piyush Desai, Thierry Kalfon, and Eivind Tandberg, based on an earlier working paper "On the directions of reform of MoFs in developing countries" that they prepared with Nicholas Calcoen and Peter Kohnert and on comments from Michael Carnahan, Nick Manning, and Dimitar Radev. The views expressed do not necessarily reflect those of the Fiscal Affairs Department. Additional material has been provided by Bill Dorotinsky, Malcolm Holmes, Nick Manning, and Richard Bontjer. 
budget management, revenue and expenditure management, accounting, debt management, and financial reporting.

This chapter will first broadly define the core public finance functions of government, and then will explore how different countries have organized these functions and will suggest some lessons of international experience. Lastly, the chapter applies all this in the Afghan context, with suggested directions for reform.

\section{Desirable Functions for a Ministry of Finance}

Generally, one can distinguish between certain "core" and "non-core" public finance functions. The organizational home for these functions varies by country. Core functions include macroeconomic forecasting, fiscal policy development, budget formulation, budget execution, debt management, revenue management, procurement policy, and treasury (cash and financial asset management). Non-core functions include financial asset management, financial investigations, lottery and gambling operations, internal audit (governmentwide), procurement management, and financial market regulation.

Describing the workings of a typical Ministry of Finance-with allowances for the diversity of international experiences and administrative structures - can put the situation of the Afghan MoF in perspective. The various ministry tasks and responsibilities can be related to all or part of the three key areas: (1) macro-fiscal policy formulation; (2) budget functions including preparation, execution, and intergovernmental fiscal relations; (3) revenue policy and administration. Accompanying responsibilities can include: financial sector regulation, aid management, personnel management, procurement, oversight of state-owned enterprises and internal audit.

\section{Macro-Fiscal Policy}

Typically, the macro-fiscal unit in the MoF is responsible for macroeconomic projections and macro-fiscal forecasting of revenues and expenditures, in coordination with other institutions engaged on related work like the central bank and central statistics office. Issues include debt sustainability analysis and the assessment of medium- to long-term estimates of contingent liabilities. These tasks pave the way for the preparation of the medium-term fiscal framework providing a basis for the annual budget of the government. In a number of countries, macrofiscal responsibilities extend to analyzing the overall economic situation, developing fiscal policy options, and assessing the impact of the government's measures on the economy. More rarely, the MoF also directly 
collects statistical and macroeconomic data normally in the domain of the central statistics office.

\section{Budgeting Functions}

Management of public expenditure requires the MoF to undertake the following core functions:

- Maintaining aggregate fiscal discipline by setting ceilings on expenditure that are binding both at the aggregate level and on individual spending entities;

- Allocating resources in accord with government priorities (allocative efficiency), a function that relates to the capacity to establish priorities within the budget and distribute resources according to those priorities; and

- Promoting cost-effective delivery of public services.

These objectives are complementary and interdependent. However, depending on the level of development of the economy, greater emphasis may be put on financial compliance, allocative efficiency, or cost-effectiveness. MoFs in developing countries typically focus on financial discipline and expenditure control.

\section{Budget preparation}

A key concern of the MoF in the budget preparation process is developing a medium-term fiscal framework and ensuring that the annual budget fully accords with the government's fiscal policy objectives. All the basic budget-making procedures-setting aggregate and sector resource allocation ceilings; drafting budget circulars, guidelines, and detailed procedures; and scrutinizing the budget bids received from the line ministries-must conform to these fiscal policy objectives. For the MoF to deliver this service effectively, it is important that budget-making responsibilities not be split between different organizations, as is often the case in countries where the capital (development) budget is prepared by the Ministry of Planning.

Thus, the MoF should be responsible for both the current and capital (development) budget and for all external and domestic financing of the budget. The planning ministry, if one exists, could still conduct project appraisal, develop medium-term priorities, and follow up on project implementation.

\section{Budget execution}

In all cases, the finance ministry is solely responsible for the custody and management of all public monies, which are usually channeled in a 
treasury single account (TSA) operated under the sole authority of the MoF. In most systems, moreover, only the MoF is authorized to borrow on behalf of the central government. It also usually maintains records of existing loans and guarantees, although debt management, if not a direct MoF responsibility, can be delegated to either the Central Bank or an independent debt management agency.

A typical MoF is involved in every stage of the expenditure cycle and would handle responsibilities for:

- Apportioning appropriations and meeting funding requirement of line ministries;

- Regulating allotment of appropriations;

- Monitoring and controlling expenditure commitments of the line ministries;

- Making disbursements against payment requests after appropriate checks;

- Establishing procedures for swift remittance of revenues tendered into the treasury account;

- Treasury operations encompassing the government payment system, banking arrangements, financing operations, and cash planning; and

- Accounting services such as maintaining classified records of revenues and expenditure transactions, reconciling government records with bank balances, generating financial management reports, and compiling the annual auditable accounts of government fiscal operations.

In countries with a decentralized payment system, the functions relating to expenditure commitment and verification of delivery may be undertaken at the line ministries subject to regulatory oversight of the MoF.

Again depending on national preferences, either the MoF accounts for government expenditure-usually through the treasury-or the accounting function is delegated to the line ministries with an obligation to report to the MoF. However, in the latter case, the MoF is still responsible for issuing directions and guidelines for setting up standard accounting procedures for all spending agencies. With regard to reporting, the MoF usually requests and puts together sectoral expenditure reports from line ministries and prepares consolidated statements for the government on a weekly, monthly, or quarterly basis depending on institutional capacities. The MoF also prepares the annual statement of accounts to be included in the Law on Final Accounts submitted to the Parliament.

\section{Intergovernmental fiscal relations}

Intergovernmental issues are relevant for both unitary as well as federal countries. Afghanistan has a unitary structure and provinces act on behalf 
of line ministries without a defined provincial budget. Accountability under this system is hard to define. In many unitary states, it would be common to find defined budgets for the lower level of administration, with clearly defined responsibilities, own revenues (needed for accountability), and transfers from the center. Under such circumstances, an MoF department would be responsible for the design of transfers and monitoring of subnational operations. Under some federal arrangements, the design of transfers may be based on assessments by an external body with participation by the lower levels of government, such as the Commonwealth Grants Commission in Australia-but with the MoF actually deciding on the magnitude of transfers.

\section{Revenue Policy and Administration}

Revenue policy is a critical MoF function. To ensure that adequate revenues are generated to fund the government's fiscal operations involves estimating the overall revenue envelope in coordination with the macro-fiscal unit, supplemented by an analysis of the available options on tax policy-including both domestic and trade taxes-to provide a more conducive investment climate and to address distributional concerns. Tax policy issues should include both domestic and trade tax (customs) issues, including the legal frameworks, establishment of rate structures, determination of bases, and gauging the interactions among taxes. A MoF revenue department would also typically address the issue of revenue assignments for different levels of government.

The above functions are best promoted by separating the revenuepolicymaking functions from the tax administration of domestic taxes (inland-revenue functions) and trade taxes (customs). Thus, in many countries, often one or two separate MoF agencies are responsible for tax administration and customs that report either directly to the minister or through a deputy minister for revenues. In such transition economies as Russia and China, the establishment of separate ministries for tax administration has led to a tension regarding tax policy-the MoF may put forward proposals that cannot be implemented, or the tax administration may end up usurping the policy function.

\section{Accompanying Responsibilities}

The range of non-core functions can be undertaken outside of the core economic and fiscal management agencies. However, their economic and fiscal significance is such that ultimately, if they are not undertaken elsewhere, they must be carried out by the Ministry of Finance or a similar body. The question ultimately is pragmatic. If no other agency can 
undertake them, then the Ministry of Finance or equivalent must, but there is a risk of underperforming core tasks by dilution of the MoF into ancillary roles.

In some countries, MoFs have specific regulatory responsibilities for ensuring that markets function on a transparent, fair, and equitable basis. More generally, however, their regulatory functions are limited to the financial markets and financial institutions and are shared with the central bank. They are generally carried out by an independent agency, such as a securities or exchange commission, outside the MoF for independence and integrity reasons. In some countries, such as Pakistan, the SEC reports to the minister of finance, even though it has quasi-legal powers.

Oversight of state-owned enterprises (SOE) provides a clear example of this. To avoid conflict of interest, this responsibility cannot be vested in any line ministry that has close dealings with the enterprises. If no other agency can or will undertake this, then the Ministry of Finance must. Frequently this function falls under treasury in terms of financial asset management, sometimes with a separate unit dedicated to SOE oversight. At the very least, establishing consistent rules for accounting, reporting, transparency, appointment of officers, and perhaps divestiture directly involves the MoF. In countries in which nonfinancial public institutions play an important role, a specific MoF department is given the responsibility for managing the relationships between the government and public enterprises, including transfers from the government, and for maintaining close oversight of their liabilities. In many transition economies, a specific structure within the MoF, or at arm's length from it, may be present to handle activities related to the privatization of state-owned enterprises.

A range of other important functions is associated with public financial management but can be viewed as non-core. It is important to distinguish here between areas the MoF has an interest in for policy or financial management reasons, and those it must carry out itself. All of these areas entail MoF policy interest, or interest for the integrity of public finances. Table 4 explores important considerations for each of these areas.

\section{Political Accountabilities-One Minister or More?}

Economic activity and the economy more broadly is the source of revenue through which the government's expenditure plan is financed, if it is to be done in a sustainable fashion. Hence, all policies that impact on the economy and likely economic growth will impact on expected revenue. 


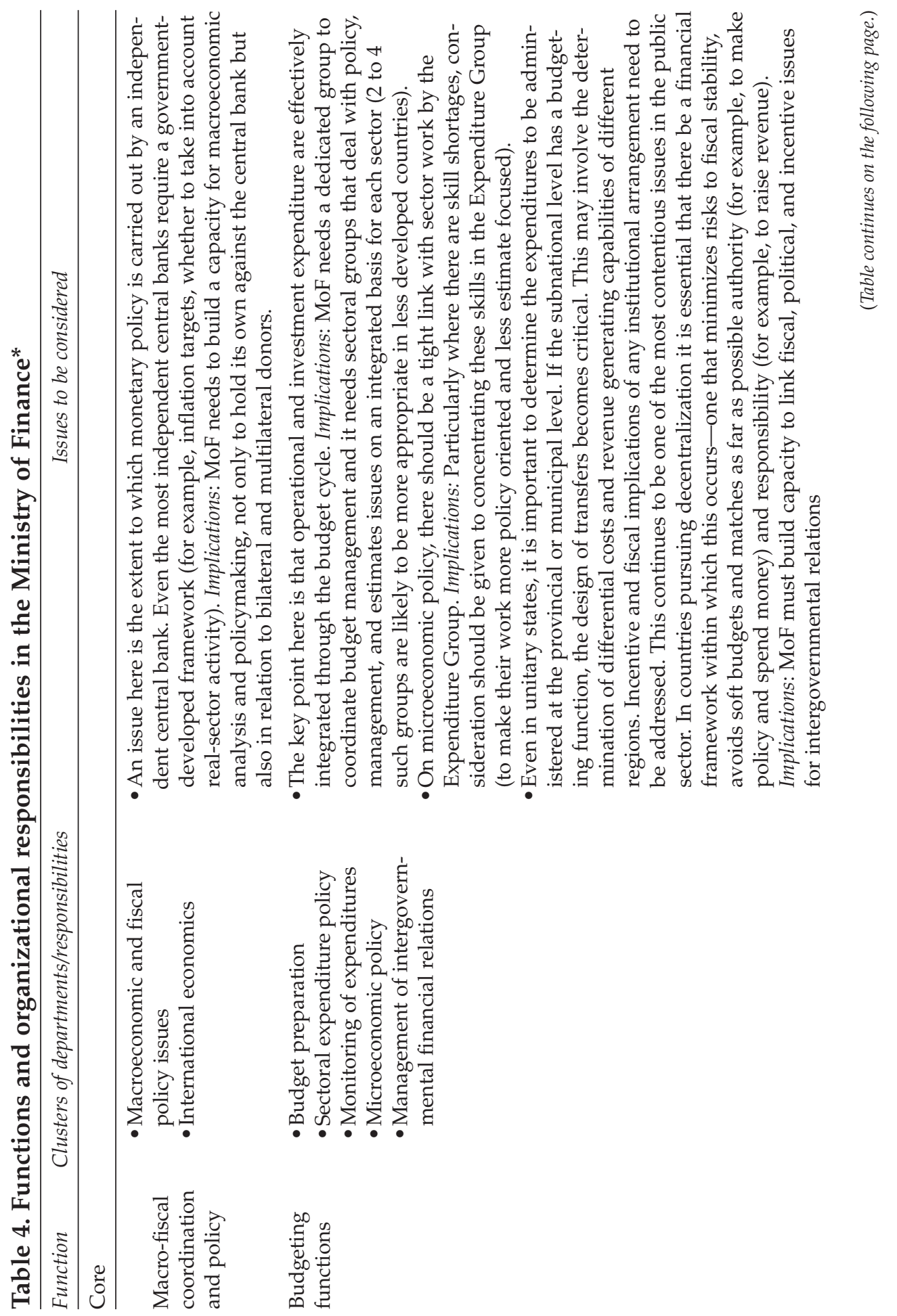




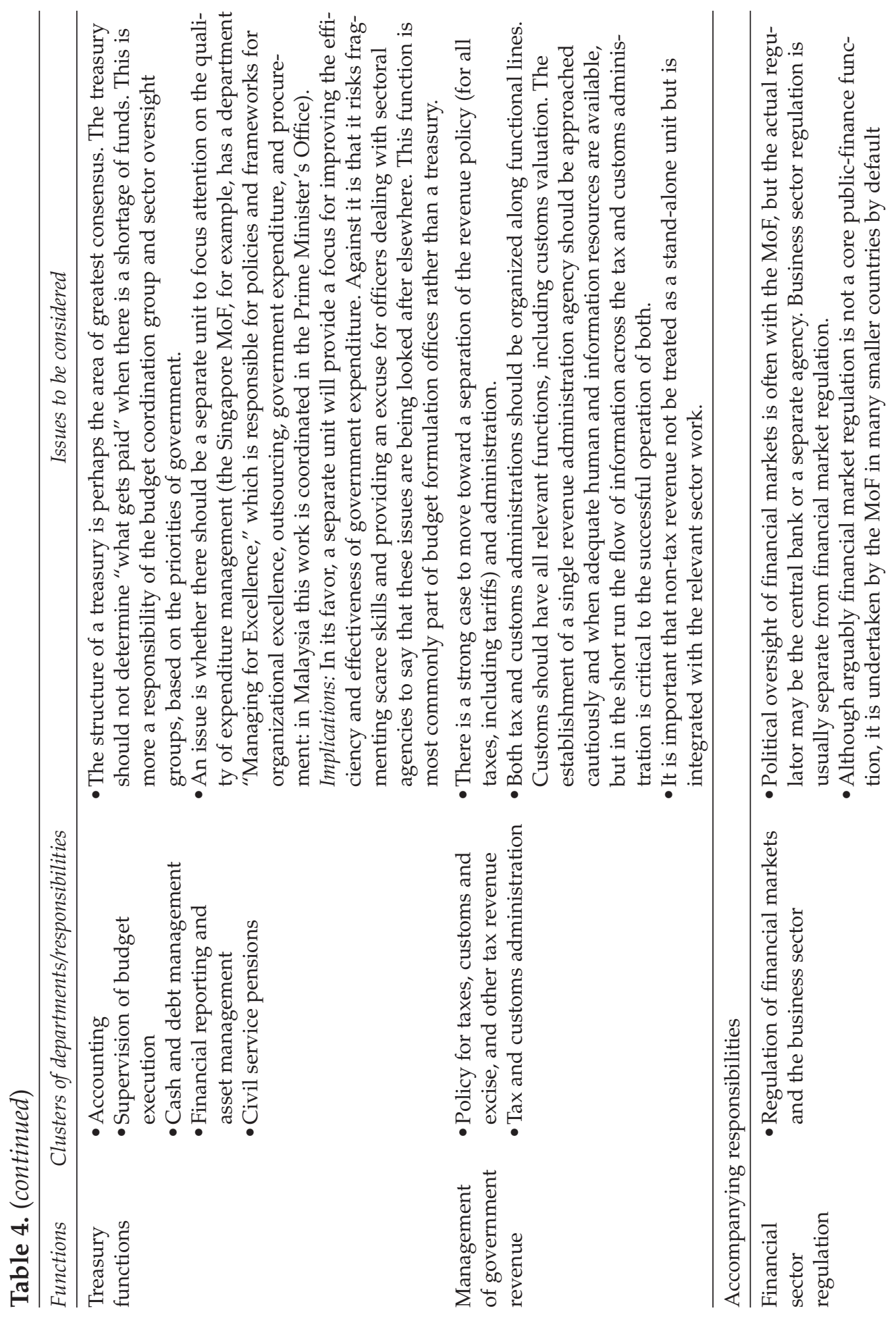




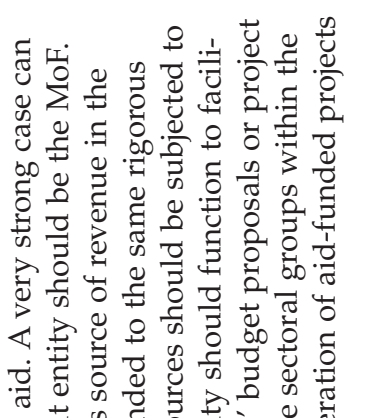

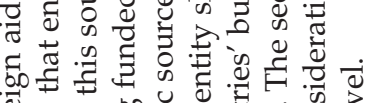

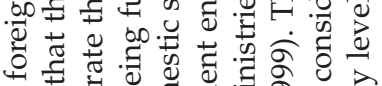

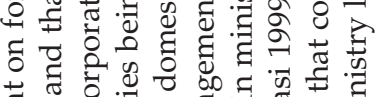

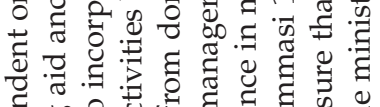
可

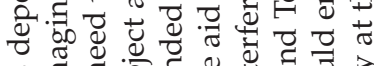

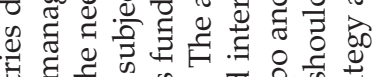
늘

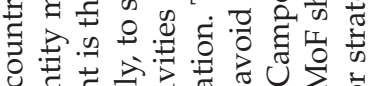

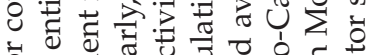

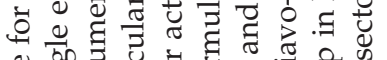

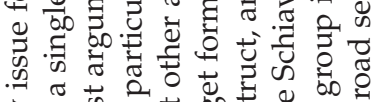
S.

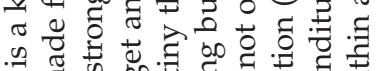
政

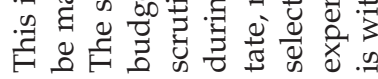

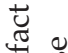

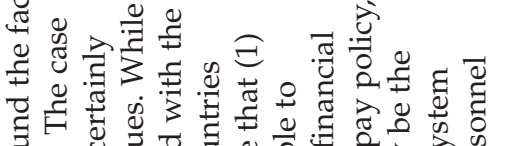

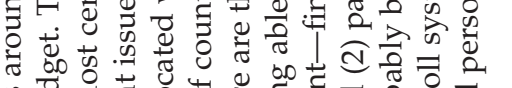

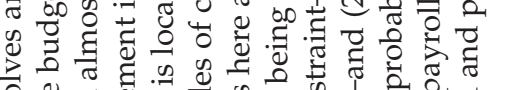

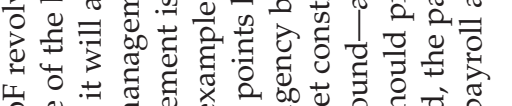

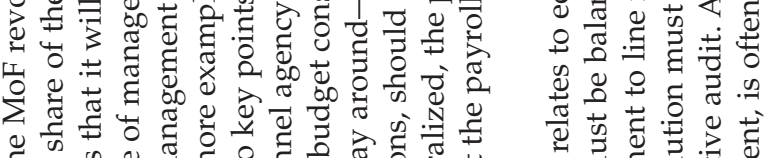
年

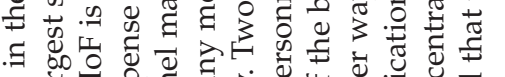

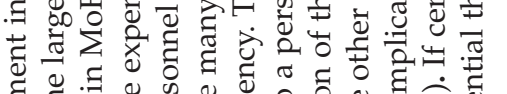

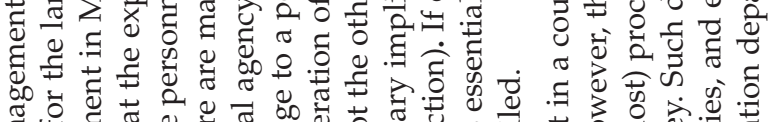

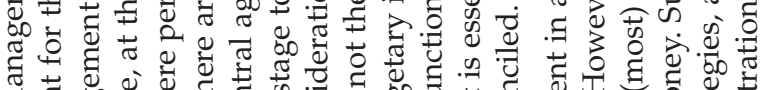

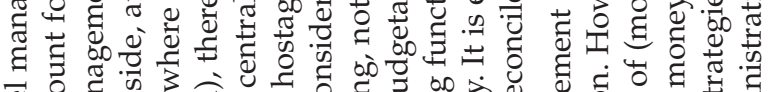

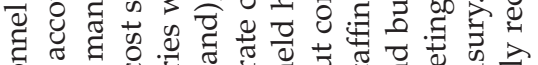
की

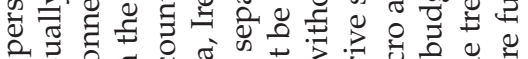

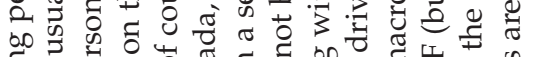

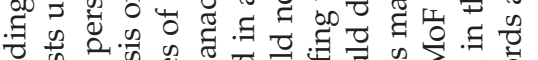
龸

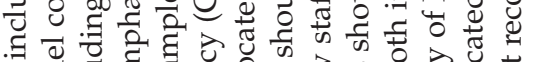

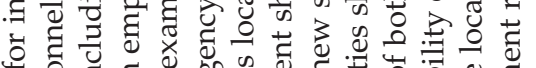

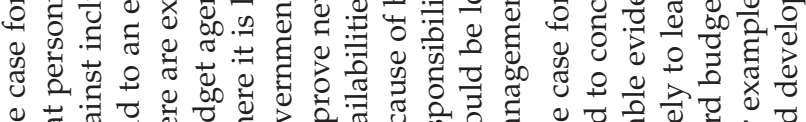

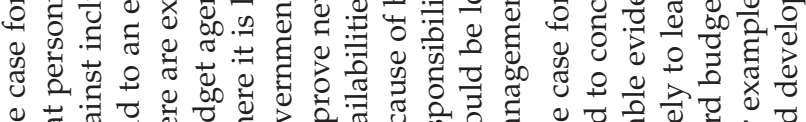

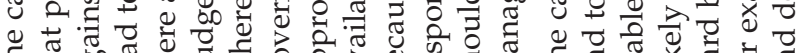
वृ 光 , 0080 : त्ञ 己ृ

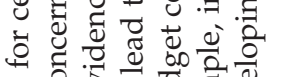

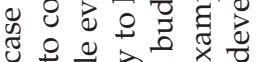

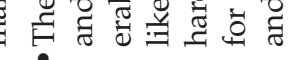

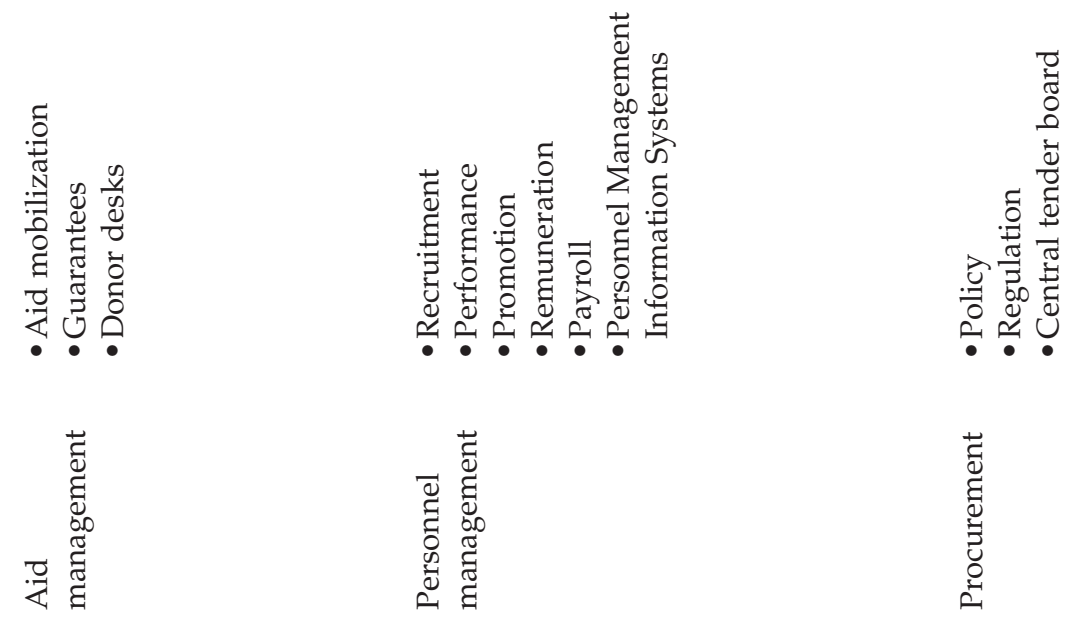




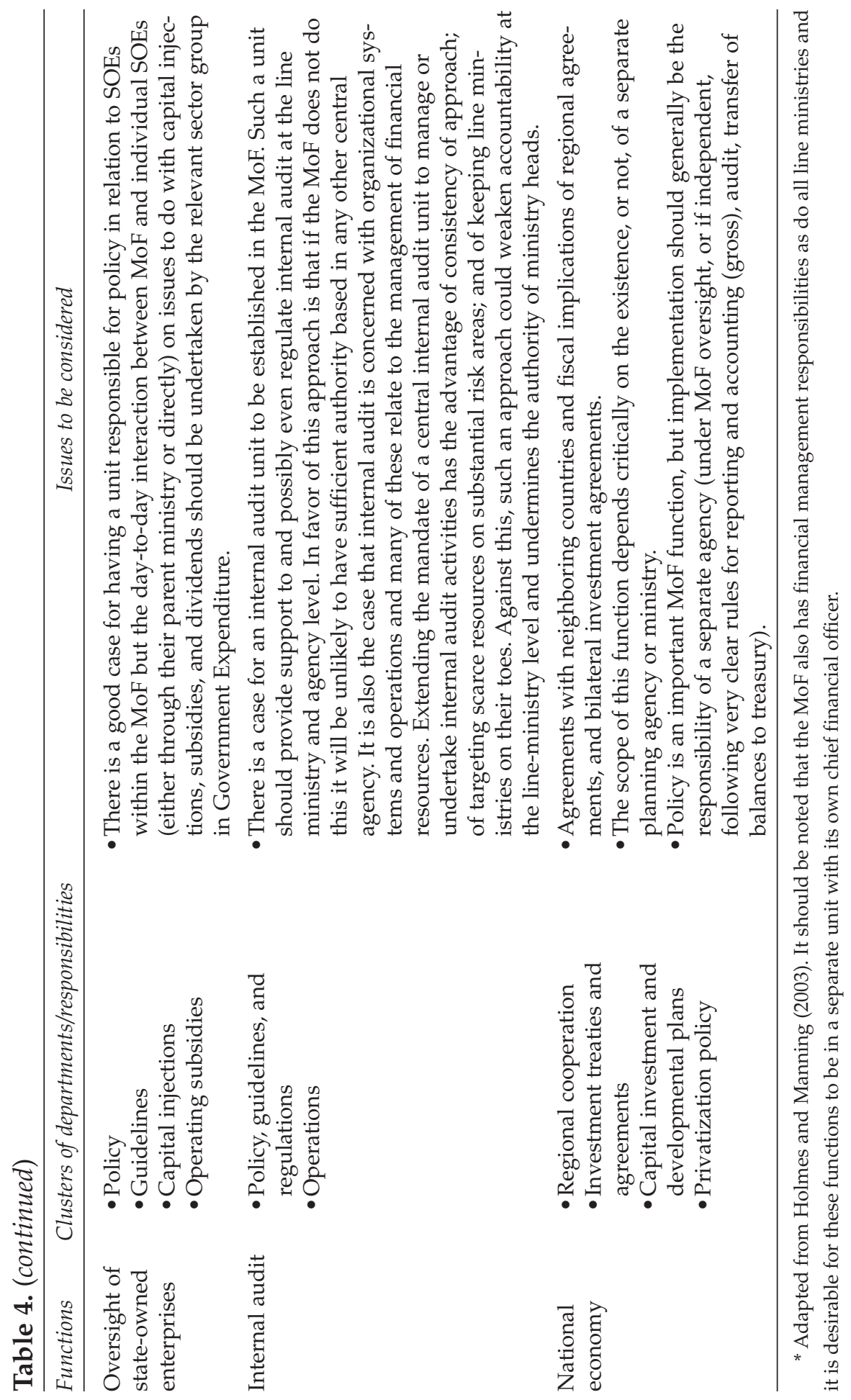


Accordingly, the finance ministry must have a key role in providing advice to the cabinet on the implications of policy choices in this area. Moreover, when economic policies will have major impacts on expenditure entitlements, or distributional effects requiring offsetting budgetary changes, the Ministry of Finance must have a key role.

The workshop identified three models for political accountabilities in fiscal and economic management:

- Two separate ministers for (1) economic policy and overall fiscal policy and (2) expenditure management.

- This is the case, for example, in Germany, where the tension between finance and economy functions remains. In such an arrangement, it is important for the MoF to have adequate means to perform its functions, for example, macro-fiscal coordination. Thus, if the economy ministry or the central bank operates macro-models of the economy, it would not be necessary for the MoF to replicate these, but to take them into account in determining the overall budgetary envelope in a medium-term context. Hungary and Poland also have this structure.

- Two separate ministers for (1) economic policy, operating budget, and revenue and (2) planning and "development" budget.

- In the former Soviet system, many countries had separate planning and finance ministries, although the nature of the planning function has been drastically modified in the more market-oriented countries. In many FSU countries, the planning commissions have been converted into ministries of economy, and in some, for example, Kyrgyz Republic, the commission has been incorporated into the MoF.

- In some countries, such as China, the planning function is accompanied by responsibility for the development budget, project aid management, and, sometimes, for macroeconomic policy. Even if a planning function is maintained separate from the MoF, it is critical that the MoF have full responsibility for current and capital budget formulation, as well as for execution.

- Single cabinet minister

- France is a case of a super ministry responsible for finance, economy, and planning, and for industrial policy and development as well. This is a very unusual case, and it may not be appropriate for a developing country with limited resources to attempt to replicate it. The Republic of Korea had a similar structure, called the National Economic Commission, for most of the last 40 years.

Table 5 offers the pros and cons.

There is also the option of a separate Ministry of Finance and Ministry of Budget. Following the example of the United States, a number of 


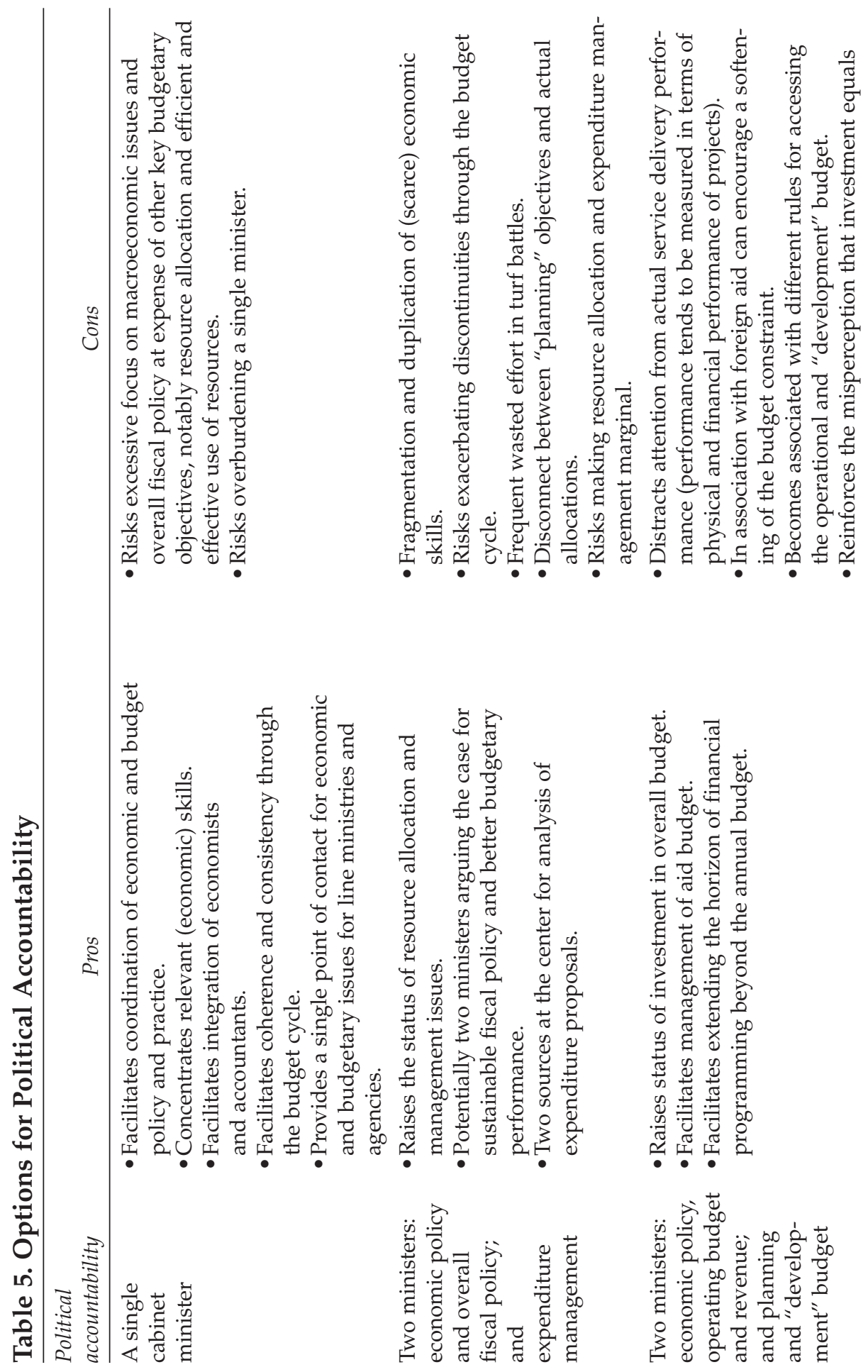




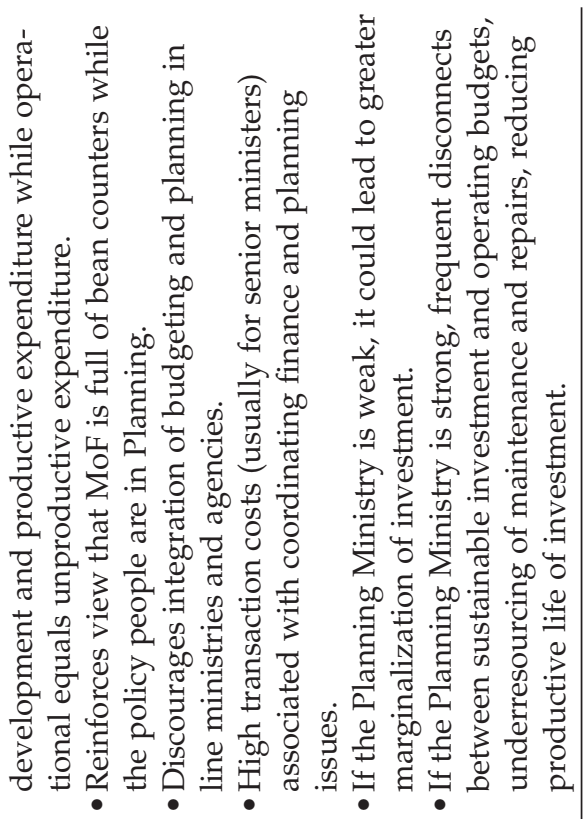

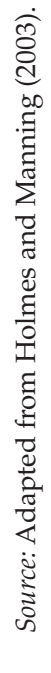


countries have operated budget formulation separate from the treasury functions, with separate ministries or agencies for each (for example, Nigeria and Iran). Mexico integrated the budget agency into the Ministry of Finance in 1992, whereas in Kazakhstan there has been a move in the opposite direction. In Latin America, strong planning functions have frequently been combined with budget functions, as was the case in Mexico. Brazil and the Republic of Korea currently have this structure.

Given the very limited human resources in Afghanistan, it is recommended that the option of a single cabinet minister for both economic and fiscal policy and management be maintained.

\section{Note}

1. Terminology can be confusing as the core ministry for managing public finances can have different names. In the United Kingdom, it is the Treasury; in Ireland, the Department of Finance; and in many others, the Ministry of Finance. This paper uses the term Ministry of Finance (MoF) to designate the central agency responsible for financial management. The term "treasury" is used expressly for the subset of functions within public finances that deals with management of cash resources. 


\section{5 \\ Making the New Fiscal Constitution Work}

On January 26, 2004, Afghanistan adopted a new Constitution. Among many crucial issues, the Constitution defines the relationship between the executive and the parliament (or legislature; the terms are used interchangeably here) in the area of economic management. ${ }^{1}$ Specifically, it defines the respective roles and responsibilities of the executive and the legislature with regard to the budget, the government's key economic policy tool.

The objective of this chapter is twofold. First, it provides some comparative analysis of the provision in the Constitution, with the purpose of underlying the critical choices embedded in this fundamental law. ${ }^{2}$ Second, based on this, it highlights other components required to make the fiscal constitution work, ${ }^{3}$ i.e., to create a system where public resources are effectively managed. This includes drafting additional laws and regulations (such as the Public Expenditure and Financial Management, or PEFM, law, presented in a subsequent chapter) and creating capacity in institutions such as the Ministry of Finance, the Supreme Audit Institution, and the Parliament. Constitutions and institutions cannot simply be transplanted; they need to be "embedded" in the social, political, and economic context of a country. The concluding recommendations on the fiscal constitution draw mainly on comparative experience; their applicability, if any, will be for Afghans to determine.

\section{A Presidential System for a Unitary State}

Among the key choices embedded in the Constitution, this chapter focuses on the choice of a presidential system, as opposed to a parliamentary system of government, and to a lesser extent, of a unitary, as opposed to a federal, system.

This chapter was prepared by Stéphane Guimbert and Joachim Wehner, based an earlier draft prepared by Joachim Wehner for the April 2003 seminar. 
In federal countries, decisionmaking is divided between levels of government. All federal systems have bicameral legislatures: a choice that has fiscal repercussions. In a federal setup, not only can subnational bodies become significant players in executive-legislative budget interaction as participants in the budgetary process in the central parliament, but also, in a bicameral arrangement, with subnational units represented in some form in a regional chamber of parliament, the issue arises what powers in budgetary matters should accrue to the regional chamber visà-vis the lower house of parliament. Politically, the constitution of Afghanistan provides for a strongly unitary system.

In choosing a presidential or parliamentary system of government, it should be recognized that the separation of powers in presidential systems tends to go hand in hand with more significant parliamentary powers over the budget and with the likelihood of greater antagonism between the branches, since such legislatures are likely to be more critical of budgets and policy proposals tabled by an executive with whom they may have little in common. Parliamentary systems, on the other hand, tend to constitutionally constrain parliament's powers over the budget. They also tend to be more conducive to cooperative executive-legislative relations because of the executive's direct and continuous dependence on majority support in the legislature.

In Afghanistan, the Constitution provides for a presidential system of government with a strong executive (art. 60): the President, elected for a five-year term, has extensive powers, chairs the government, and cannot be recalled by the National Assembly (he can only be impeached in special circumstances, art. 69). The Constitution also states that the Islamic Republic of Afghanistan is a unitary state (art. 1), but allows for experiments with deconcentration. ${ }^{4}$

\section{Implications of the 2004 Constitution}

\section{Bicameral Design}

The first feature of a fiscal constitution that has an impact on budget outcomes is the structure of the Parliament. The National Assembly will be composed of two houses: the Wolesi Jirga, House of the People, with 220 to 250 members, elected for five years (their constituency will be determined by law) —and the Meshrano Jirga, House of Elders, with representatives of provinces (elected for four years) and districts (three years), as well as 50 experts chosen by the President (five years). The upper and lower houses have asymmetric powers with regard to the budget.

In most cases where regional chambers have unequal or nominal budgetary powers ${ }^{5}$, the upper houses are indirectly elected and represent 
either state legislatures or state executives. For example, Germany's Basic Law (1949) requires the consent of the regional chamber of parliament, the Bundesrat, for revenue measures with an impact on the receipts that accrue wholly or in part to the states, or Länder. The consent of the Bundesrat is, however, not required for the expenditure side of the national budget. In this case, the lower house, the Bundestag, is decisive. Nonetheless, these provisions award regional executives a direct veto opportunity with regard to the revenue measures proposed by the center. In federal countries where revenue sharing is the principle mechanism of financing subnational entities, legislative approval of revenue-sharing measures by the regional chamber seems an appropriate constitutional requirement.

In some countries the regions merely have the nominal power of "having to be heard" during the budgetary process in the national legislature. For example, section 109 of the Constitution of India (1950) allows the Council of States, or Rajya Sabha, to make recommendations to the House of the People, or Lok Sabha, when it comes to budgetary matters. These recommendations can be rejected or accepted by the lower house with a simple majority vote, which would be a minor inconvenience. This arrangement, in effect, precludes a veto possibility through the regional chamber.

In Afghanistan, the budget will be submitted through the upper house, the Meshrano Jirga, with an advisory comment from the lower house, the Wolesi Jirga, but the latter will have the final word (art. 91/98). A law on the role of subnational bodies could consider linking the possibility to extend the role of subnational bodies (as suggested by articles 137 and 139) and the role of the upper house.

\section{Budget Presentation}

As with many other constitutions, the 2004 Afghanistan Constitution has provisions that govern the passage of finance, budget, or money bills. It is important that a fundamental law requires approval of both expenditure plans and any new revenue measures: in Nigeria, where that requirement was omitted for the revenue side, a substantial accountability gap and much acrimony between the executive and legislative branches have arisen.

On the expenditure side, most legislatures approve appropriations in one law, and most require voting each year on statutory or entitlement programs, which are based on "permanent" legislation, together with all other expenditures. Where (notably in Japan and the United States) expenditures on statutory or entitlement programs are presented to the legislature for information only, parliament can only change such 
statutory spending by amending the underlying statute rather than the budget. On the revenue side, taxation measures tend to remain in force unless they are explicitly amended, or unless the legislation that imposed them is time bound and expires at a specified date.

To consider the budget adequately, parliament needs information about macroeconomic assumptions, fiscal policy, revenue sharing arrangements, and spending priorities, for example, all of which require narrative information and statistical data that are not normally part of budget legislation. The Public Expenditure and Financial Management (PEFM) law sets high standards in terms of information to be included in the budget document. Since parliaments also benefit from information generated by medium-term budgeting frameworks, and from assuring access to certain information at certain times and in certain formats, parliaments should have a say in determining the format of budget presentation as well as supporting documentation and other relevant information.

\section{Timing}

In cases where the budget is not passed by the beginning of the fiscal year, constitutional practice falls into two broad categories: countries where interim spending without explicit legislative authorization is condoned and countries where it is not. Several constitutions (for example, the 1958 French Constitution) provide that the executive's draft budget can be implemented if the budget is not passed by the beginning of the fiscal year. Like most constitutions, the Afghan Constitution provides an interim spending formula for cases of delay (using the previous year's budget, art. 98): as in many other cases, this rule is based on the previously approved budget and applies only for a limited period. However, to avoid stalemate and the disruption of services that the country can ill afford at present, the Afghan Constitution establishes that after one month into the new fiscal year, if the legislature still fails to approve the budget, the budget is considered approved (similar to the provision in the French Constitution).

Taking the U.K. example, to put this in some context, the British Parliament devised the tactic of voting appropriations near the end of the session as a means of forcing the Crown to utilize its own resources before relying on tax revenue raised from the public. In a modern context, however, this antiquated tradition weakens parliament by complicating an approval process that should aim at advance scrutiny. Regrettably, too many countries following the Westminster tradition of parliamentary government have copied this poor practice, demonstrating how institutional replication makes little sense without reflection on the particular historical and political context. The effect, under today's budgetary 
conditions, of the late tabling of the budget is to undermine effective financial scrutiny. The 2004 Afghanistan Constitution only requires submitting the budget "in the last quarter of the year" (art. 98).

Yet, the parliament should have sufficient time to engage with the draft budget, to facilitate meaningful analysis and scrutiny. The less time the legislature has to approve a budget, the less influence it is likely to yield. Depending on points of view and political values, less time for parliament might or might not be desirable. Any period shorter than two or three months to deal with the budget will undercut the potential for meaningful parliamentary engagement. Many countries have chosen to establish in their constitutions a minimum amount of time (for example, at least 60 days in Madagascar) parliament must have for consideration of the budget. Once the Parliament is set up, the relevant best-practice recommendation of the Organisation for Economic Co-operation and Development (OECD) deserves incorporation into the PEFM law:

The government's draft budget should be submitted to Parliament far enough in advance to allow Parliament to review it properly. In no case should this be less than three months prior to the start of the fiscal year. The budget should be approved by Parliament prior to the start of the fiscal year. (“OECD Best Practices for Budget Transparency," 2001, p. 4.)

\section{Amendment Powers}

Different legal traditions have produced a pattern according to which legislative powers to amend proposed budgets are more likely to be circumscribed in parliamentary systems than in presidential ones. The less amendment powers are circumscribed, the less control over the budgetary outcome is left to the executive alone.

Legislative powers decrease along a continuum with United Statesstyle checks on the executive giving Congress unfettered engagement with the budget (table 6). In theory, unfettered powers allow the legislature to completely revise the executive's draft budget. Elsewhere, in particular in many francophone countries and parts of Latin America, "balanced budget" amendment powers allow changes as long as they bring no increase of the deficit. Such powers usually require parliament to maintain a balanced budget by legislating either higher revenues or matching savings to cover any spending increase. This leaves parliamentary scope to engage with the prioritization of spending, notably, while safeguarding the fiscal balance.

Finally, a set of countries severely restrict amendment powers. In the Westminster tradition of parliamentary government, "reductions only" restrictions apply; parliament may only reduce existing items but not 
include new ones or increase existing ones. This leaves minimal real scope for amendment activity, but the possibility of expenditure cuts can protect against spendthrift tendencies in the executive. In the Westminster tradition, attempts by parliament to amend the budget proposal of the executive, if successful, are by convention considered tantamount to a vote of no confidence in the government. The last time the British Parliament voted down a request for money was in 1919, when the Lord Chancellor was refused funding for a second bathroom. The minimum common denominator across the various amendment traditions is the power to reduce existing items. More restrictive provisions are exceptions: one example is section 57(1) of the Constitution of the Republic of Malawi, which prohibits the National Assembly from dealing with or amending the budget, except when requested by the minister responsible for financial matters.

Although many analysts believe that weak parliaments are conducive to ensuring fiscal discipline, strong counterarguments hold that a parliament with no significant powers to amend the budget will also have no incentive to engage with it. International experience shows that this leads to a decline toward an undesirable, mere rubber-stamping function. The absence of effective financial scrutiny by parliament, in particular in many developing countries, creates accountability gaps that prolong poor budgeting practices and become a breeding ground for corruption in the use of public funds.

The 2004 Afghanistan Constitution calls for a very strong presidential regime, with limited amendment powers for the legislature, in particular for the budget. ${ }^{6}$ As indicated above, the challenge will therefore be to get the Parliament to engage on the budget: without direct power in the budget process, a disenchanted legislature could refuse any engagement on the budget, reducing transparency and accountability, or even could

\section{Table 6. Budget Amendment Powers of National Legislatures}

\begin{tabular}{lc}
\hline Power & Countries \\
\hline May reduce and increase expenditure and revenue & 32 \\
May reduce but not increase expenditure & 17 \\
Not specified & 15 \\
May reduce and increase expenditure if alternative provisions & 13 \\
$\quad$ are made elsewhere & \\
May reduce expenditure, but only increase it with the permission & 4 \\
$\quad$ of the government & 81 \\
\hline
\end{tabular}

Source: Inter-Parliamentary Union (1986, table 38A). 
refuse any cooperation with the government, thus obstructing legislative activities. The implications of this feature are further detailed in the next section.

\section{Modifying the Budget during Execution}

Continuous budgeting - the practice of changing budgeted amounts during implementation-is a symptom of a weak budgeting system, and it undermines the authority that constitutions impart to parliament by requiring their approval of the budget. Unfortunately, in many developing countries, it is not unknown for variance between approved and actual spending to spill into double-digit percentages. The Afghan Constitution does not provide for strict governance of adjustments to the budget during implementation but such governance will be included in the PEFM law.

Although many constitutions require supplementary estimates to capture and approve any such changes, that practice should be minimized in order to preserve the integrity and comprehensiveness of the budget. The extent to which supplementary estimates are used is an indicator of the accuracy and reliability of the budget system. The greater the number of supplementary estimates used-other than in exceptional circumstances, such as wars or natural disasters-and the greater the sums involved, the less reliable is the overall system. Contingency reserves that provide for such unexpected conditions may well be warranted, especially given the uncertainties of budgeting in a developing country context, as long as they do not degenerate into "slush funds" for the executive. Requiring legislative approval for any allocations made from a contingency reserve, for instance in adjustment appropriations, guarantees a degree of legislative oversight.

In the case of unexpected savings or proposed transfers between budget categories, virement provisions are more commonly found in financial management legislation than in constitutions. South Africa's Public Finance Management Act (1999), for instance, allows the accounting officer of a department to utilize savings under a main division within a budget vote to be used under a different main division within the same budget vote. In effect, this limits shifts in funds to adjustments between program spending levels within the same departmental budget. The amount shifted from one program may not exceed 8 percent of the appropriated amount. New Zealand's Public Finance Act (1977, as amended) is slightly more stringent; it limits the "transfer of resources between classes of outputs" to a maximum of 5 percent.

The draft PEFM Law includes a very restrictive provision by which transfers are authorized within a ministry for small amounts (less than 5 
percent of the appropriation the amount is transferred from). It also specifies that revised and supplementary budgets should follow a process similar to the original budget.

\section{Legislation with Budgetary Implications}

Ordinary legislation introduced during the course of a financial year may well have budgetary implications, if, for example, it creates or increases entitlements that conflict with the constraints of the approved budget. Although some constitutions provide a role for the executive in ensuring that legislation introduced has no consequences for the current budget year, in most countries, legislation is prepared and drafted by the executive. The Afghan Constitution indicates that legislation with budgetary or financial implications should be initiated by the executive. The requirement for the proper costing of draft legislation is included in the PEFM law. Also, for measures with revenue implications, the Constitution ties the executive's hands since an alternative source of revenue has to be identified.

\section{Executive Reporting and Audits}

For parliament to ensure that expenditure and revenues that it has approved are fully implemented, tradition has entrusted the audit of government accounts to a body distinct from the legislature, such as an Auditor General or a Cour des Comptes, but nonetheless in support of the latter's oversight function. A core task of the audit institution is to conduct an annual audit of government accounts, but it should also be empowered to issue special reports when this is deemed necessary.

An audit report should be produced as speedily as possible to ensure its relevance. The Afghan Constitution sets clear requirements to prepare audited accounts in six months. Long delays in the submission of the audit report carry the risk that officials responsible for a loss of public money have moved on or retired by the time the relevant incident receives attention. The interest of the public is also likely to focus on more current matters. This may make it more difficult to pursue disciplinary measures.

Importantly, the PEFM law grants the external auditor unrestricted access to information. Since, contrary to the recommendations of a group of Supreme Audit Institutions (the Lima declaration), there is no such provision in the Constitution, strong provisions on the independence of the auditor general have to be included in a separate law (for example, an audit law). ${ }^{7}$

To meet constitutional or legislated deadlines of six months after the end of the fiscal year, audit institutions in many developing countries 
need capacity-building help. A recent study of five African countries showed that audit reports are, on average, tabled in the legislature about two years or more after the end of a financial year, whereas the legal deadlines varied between 6 and 11 months (Fölscher 2002, p. 42). Financial support from donors is needed to strengthen local audit expertise, and to modernize the audit systems appropriately to benefit from advances in information technology, for instance.

Although constitutions tend to focus on ex post accountability arrangements through an audit process that involves the legislature, this should not be read to negate the importance of oversight during budget execution. This involves the regular publication of in-year actual expenditure and revenue information as an aid to transparency and accountability. High-level requirements included in the Constitution (art. 98) and additional requirements in the PEFM law (detailed quarterly reports) need to be complemented with more detailed specifications-as recommended in the "OECD Best Practices for Budget Transparency" (2001) — in financial management legislation.

\section{The Role of the Parliament}

No written text can define the nature of executive-legislative relations over the budget, especially the dynamics that arise from the interplay of parties in the nation and in the legislature, the cohesion (or lack of it) within parties, and even the conditions that donors often attach to their support. Two elements that merit particular attention are: the structure and work of the executive and the capacity and strength of the legislature. The structure of the executive and in particular the role of the Ministry of Finance are well-explored elsewhere in this book. This section focuses on the capacity of the legislature. The role of subnational bodies and other stakeholders is an additional significant issue.

In the Afghan Constitution, the parliament has a limited role in budget preparation. To avoid a complete disengagement from-and probably disenchantment with - the budget, it is important that, within this limited role, the parliament possess the requisite resources and information, organizational structure, and process by which to render effective judgments on the budget. Such technical capacity is necessary to make full use of the limited space it occupies and to make sound budgetary choices in doing so. A more important engagement could come for the parliament's role in monitoring the execution of the budget and making the executive accountable for it. Some of the key variables that combine to determine the technical capacity of parliament to engage with the budget are budget literacy, information availability, and the strength of its committees. 


\section{Budget Literacy}

Building adequate technical capacity will be especially important in the Afghan context, where the legislature will be newly constituted, and the executive is not used to parliamentary participation. There, as elsewhere, the ability to make changes to budgets depends on detailed scrutiny that is only possible with detailed analysis. The first possibility for parliament to access independent information and analysis on the budget is through its own research service. Given the size and technical nature of the budget, effective research services require specialized personnel, such as the highly trained 245-member staff of the U.S. Congressional Budget Office and the almost 50 employees in the Congressional Planning and Budget Office of the Philippines. Some parliaments have smaller research units that specialize in budget analysis, for example, in Poland, and yet others have general research units that can deliver some budget analysis when needed, such as the Research Service of the House of Commons Library in the United Kingdom. However, in many developing countries, parliamentary research capacity is often negligible or nonexistent, perhaps due to lack of resources or skills. Even without a research department, it is critical to build capacity among parliamentarians on financial affairs to support constructive engagement on the budget. ${ }^{8}$ Exposing the new Afghan parliamentarians to others with similar responsibilities in other countries so that they would acquire these essential skills could be a very efficient way for them to get their bearings. Finally, it would be valuable to get external stakeholders (for example, NGOs) to provide independent budget analysis. ${ }^{9}$

\section{Information Access}

Parliamentary decision making needs to be based on comprehensive, accurate, appropriate, and timely information supplied by the executive. The amount of supporting documentation that accompanies the budget figures is crucial. In many countries, the budget document itself contains little narrative that outlines the policies underlying tax and spending proposals. Often the only source of narrative information is the budget speech. This makes it difficult for parliament (and civil society) to understand the policy basis for the budget and to evaluate whether the budget adequately reflects stated government policy. Also needed, as noted earlier, are in-year actual spending information and timely, thorough, and well-presented audit reports. Budget implementation is a crucial issue in many developing countries, where unauthorized expenditures and the difference between approved and actual budget numbers can routinely run into double-digit percentages. Budgetary decisions 
should be made in the knowledge of actual spending, rather than on the basis of budgeted figures that might be little more than budgetary fiction. The PEFM law sets standards for the form of budget presentation and for reporting on budget execution.

\section{Parliamentary Committees}

Committees are the "engine room" of parliament. It is here that in-depth and more technical debate can take place, away from the political grandstanding that often characterizes proceedings on the floor of the house. The stronger parliament's committees are in the budgetary process (budget formulation, monitoring, and audit), the greater parliament's ability is to engage with the budget. Where the committee stage is underdeveloped, and discussion takes place mainly on the floor of the house, the budgetary role of parliament is weak (for instance in the United Kingdom). Internationally, the trend seems to be toward broader committee consultation in the budgetary process. For instance, the Australian Senate introduced a departmental committee stage in 1970, India in 1994, and recently, the parliaments of Uganda and Zambia have created new committees that consider budgetary issues. Although these initiatives may have been implemented with varying degrees of success, they give an indication that parliaments themselves have realized the value of committee involvement in strengthening approval and oversight capacity.

For Afghanistan, a budget committee should have jurisdiction to consider the budget. Until the system settles down, it might be prudent not to involve sectoral committees in the budget, but ultimately this might become desirable. The debate of the budget should be balanced between the committee and the floor of the house, and the committee should have sufficient time to analyze and act. Its discussions should be transparent. The public and media should have access to committee deliberations, documentation, and reports.

\section{Conclusions and Recommendations}

The international experience described in this chapter suggests a number of areas where the Afghan Constitution will need to be complemented by passing other laws and by strengthening capacity of key institutions. The PEFM law is a first step in that direction, but additional financial legislation is required. In addition, capacity should be built in the parliament to effectively engage on financial affairs.

The Afghan Constitution significantly limits the power of the parliament to intervene in financial affairs. A great risk is that the executivelegislative dynamics that will unfold turn into a disengagement of the 
parliament from these affairs, which would have adverse consequences on governance-at least by reducing accountability, transparency, and debate in the decisionmaking progress on these matters. To mitigate this risk, as described above, the public finance framework needs:

- Comprehensive, accurate, appropriate, and timely information (for the draft budget as well as for reports on budget execution);

- Adequate time for the parliament to consider the draft budget;

- Clear boundaries on executive and legislative roles (for example, on modifications of the budget without parliamentary approval and on new legislation with budgetary implications);

- A strong Supreme Audit Institution with adequate prerogatives and capacity (including the executive's commitment to address the auditor's observations);

- Adequate budget analysis capacity (parliamentarians' familiarity with budget issues; a small, specialized budget analysis unit; and analysis provided by external stakeholders, such as NGOs); and

- Strong parliamentary committees.

\section{Notes}

1. This chapter is based on the English translation of the Constitution available

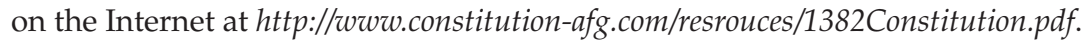

2. A useful source of relatively up-to-date constitutional data is the International Constitutional Law Index available on the Internet at $h t t p: / / w w w . o e f r e . u n i b e$. $\mathrm{ch} / \mathrm{law} / \mathrm{icl} / \mathrm{index} . \mathrm{html}$. Most of the examples of constitutional provisions that are cited in this text can be accessed via this website.

3. A fiscal constitution is defined as the most fundamental set of legal rules or deeply entrenched conventions of a state that frame the governmental activities of obtaining revenues and allocating expenditures. Most fiscal constitutions are contained in written constitutions, some bundled as a financial chapter. But in some countries, notably Britain, the fiscal constitution consists of fundamental unwritten conventions (Wehner 2002, pp. 217-19). While written parts of a constitution are enforceable via the courts, unwritten conventions are enforced primarily by the dynamics of tradition, conscience, and public opinion.

4. "The government, while preserving the principle of centralism, shall-in accordance with the law-delegate certain authorities to local administration units for the purpose of expediting and promoting economic, social, and cultural affairs, and increasing the participation of people in the development of the nation" (art. 137).

5. In cases where the two houses are coequal in budgetary matters, the regional chamber is likely to have been directly elected (for example, the Australian Senate). 
6. The National Assembly can set up commissions to study topics and ratify/modify laws; it can initiate legislation, but not the budget or financial related laws (art. 88-96).

7. Commenting on the design of the audit institution would go too far beyond the scope of this chapter. For useful guidance, refer to the Web site of the International Organization of Supreme Audit Institutions (INTOSAI) at http://www. intosai.org, which includes a survey of mandates of supreme auditors.

8 . The 1384 budget legislation is likely to be some of the first legislation that the new Wolesi Jirga confronts. As happened in East Timor, many of the procedures of the legislature will be developed in a "learning by doing" fashion as the legislature struggles with the complexities of the budget.

9. Detailed information on applied budget work by civil society organizations

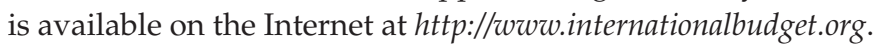




\section{6 \\ Budget Law Reform}

\section{Introduction}

New budget legislation is an important element in budget management reform. The clearest examples in this regard are in the former Soviet Union, where all the countries have passed new budget legislation since 1990, and in the OECD, where most countries have passed such legislation over the last two decades.

A new budget system law, referred to as the draft Public Expenditure and Financial Management law (PEFM law), is presently in an advanced stage of drafting and consultation within the government. It is envisaged that the new law will be enacted shortly after the commencement of the SY1383. The draft PEFM law will be a critical measure to consolidate the budget reforms in Afghanistan and a key complement to the new Constitution.

\section{The Objectives of a Budget System Law}

\section{General}

The law should be introduced by specifying that the budget system law regulates all aspects of government budget management, at all levels of government, and in all parts of the country as well as outside the country. In addition, some protection should be provided to restrict amendments to this fundamental law. A number of key public finance principles should be made explicit: The government can raise revenues, incur expenditures, raise loans, or issue guarantees only with an authorization in law; and it is accountable to the legislature for the use of these funds.

This chapter was prepared by Richard Bontjer, Stéphane Guimbert, and Eivind Tandberg, based on an earlier paper prepared for the April 2003 seminar. 
A general or consolidated fund of the government should be created: all revenues of government organizations, regardless of their sources, including grants, fees, and other revenues collected by individual government organizations, will be transferred to this fund. In other words, no government organization can retain these funds for its own use. In the case of municipal administrations, exemptions apply to the general rules.

Then the budget should be defined in broad terms, setting key budgeting principles:

- Periodicity: the fiscal year should be defined.

- Universality: the budget should present all revenues and expenditures on a gross basis.

- Classification: the budget should be classified according to internationally accepted standards and principles, including specification of organization, function, economic object, budget program, project and funding source, as applicable.

- Unity: the budget should cover all central government organizations and activities and all revenues and expenditures related to these organizations. It should cover the operations of any extra-budgetary or special funds. It should also include a specification of government guarantees. While the operations of commercial entities owned by the government should be excluded if these are organized as separate legal entities according to applicable law, their financial relationship with central government should be specified.

- Transparency: the government should commit to take all practicable steps to ensure that the public has full access to fiscal information, including the details of the budget proposal for next year, after it has been submitted to the legislature, and budget execution results for the current year.

The budget system law should set out the broad principles of financial management. To allow sufficient flexibility to modify procedures under these principles, the budget system law should authorize the cabinet and the Ministry of Finance (MoF) to issue the regulations that are required to implement this law.

\section{Budget Preparation and Amendment}

The first step in budget preparation should be that the cabinet sets the overall context of the budget. It is good practice to base the budget formulation on a medium-term macroeconomic framework, covering the budget year and the next three years, updated annually, and on a multiyear national development program. Early in the year, on the basis of the macroeconomic framework and the national development 
program, the cabinet can determine the overall ceilings for revenues, expenditures, and financing for the next budget year, as well as aggregate expenditure ceilings for each ministry. The cabinet may also determine indicative ceilings for the three years following the budget year.

The second step is usually the preparation of draft budgets by each ministry. The MoF issues a budget circular outlining the budget preparation process and timetable for the following fiscal year and providing the necessary information for the line ministries to prepare their budget proposals. This circular should be clear and distributed well in advance to allow real budget preparation in the government. Ministries should prepare draft budgets for their policy areas within the resource allocations approved by the cabinet. The draft budgets should cover all budget organizations and programs within a ministry's policy areas, including the operations undertaken by subordinate organizations and in provincial bodies of the ministry. The budget submission should include a specification of all expected revenues and expenditures, as well as any loans and repayments, proposed state guarantees, or other forms of liabilities. New policy proposals should be specified and fully costed. The draft budgets should also include indicative estimates for the three years following the budget year.

The proposed budget would be reviewed and discussed by an Expenditure Review Committee (ERC), which is a subcommittee of cabinet. Each year, the ERC should prepare a draft budget law based on ministries' submissions: a mechanism should be set to resolve disagreements in this process. The annual draft budget law must include all central government revenues, expenditures, and financing items. This draft should also include a specification of authorized government positions, according to ministry and broad employment category, and a specification of outstanding and planned guarantees. It should allocate expenditures by ministry (with suballocations by subfunction or program and by broad economic category). The budget system law can be specific in terms of the main headings to be covered in the budget law. The draft law should be presented to cabinet for consideration and approval.

This draft budget should be submitted to the legislature in sufficient time for review and debate (usually at least two months before the beginning of the next fiscal year), including the information necessary to review it thoroughly. This includes a detailed analysis of the current economic and fiscal situation and prospects for the coming years; information on the total debt stock and on contingent liabilities, information on the regional distribution of budget funds; description of budget programs and projects, including the objectives and expected benefits of these; and expected revenues, expenditures, and financing operations for the three years following the budget year. 
The legislature should approve the annual budget law before the beginning of the new fiscal year. Deliberation and approval of the budget law can be done in two stages. The first decision establishes the overall ceiling for revenues, expenditure, and financing. The second decision determines the detailed appropriations. In many countries, constraints are put on the legislature to restrict its ability to amend the budget law.

If the legislature is not able to approve the draft budget before the beginning of the fiscal year, a mechanism should be set to authorize that expenditures be made. For instance, the cabinet can be authorized to approve government spending for one month at a time; a restriction should be made, such as a spending limit for the month (for example, $1 / 12$ of previous year's approved budget) and a restriction on financing any new projects or programs.

The budget system law should also specify how the budget could be revised. During the year, the MoF should review budget execution results and advise the cabinet on the need to submit a proposal for budget amendments to the legislature. An increase in the budget deficit, reduction in the budget surplus, or increase in the aggregate expenditure level during the budget year must be submitted to the legislature for approval. Transfers between appropriations should also require approval by the legislature; however, within the appropriated budget of a ministry, the cabinet should be authorized to transfer funds between ministries (or subfunctions or programs depending on how the budget is formulated), and between economic items, not exceeding a specified share (for instance, 5 percent) of the original budget appropriation. The cabinet can delegate this authority to the MoF and the line ministries, within specified limits.

In addition, all bills submitted to the legislature during the budget year should be required to include a specification of their budgetary implications and a proposal for budget amendments to cover these implications, as appropriate.

\section{Budget Execution}

The MoF should approve a financial plan for the budget year, specifying the funds that will be made available to the ministries during the year (by quarter or by month). This plan should be approved very early in the year (for example, by the end of the first month). Alternatively, funds may be automatically allotted based on plans submitted during the budget review process. For example, first-quarter allotments can be based on 25 percent of the total year appropriation for that year. The allotments should be subject to review by the ERC, in particular addressing expenditure equity issues across provinces and minor budget units. 
All government funds should be held in the treasury single account (TSA) in the central bank. All state revenues must be transmitted to the TSA without delay, and all state expenditures must be paid from the central treasury. Government organizations should not maintain separate bank accounts or keep cash resources, without written approval by the MoF. All payments to and from the budget must be made through the exchange of funds: offsetting transactions between budget revenues and payments should not be permitted.

Budget commitments and payments must be approved by the MoF or its authorized representatives. In a situation of cash shortage, the MoF is authorized to reduce commitments and payments below the allocations in the annual financial plan. A specific prioritization plan should be approved by the cabinet to regulate these reductions.

Unless otherwise specified in the annual budget law, budget appropriations and cash allocations usually lapse at the end of the fiscal year. The cabinet may issue regulations for transferring unused budget appropriations to the next fiscal year, in order to avoid inefficient spending at the end of the year. However, such transfers should be capped (for instance, at 10 percent of the budget appropriation for the fiscal year).

\section{Budget Reporting}

Most issues of budget reporting should be ruled by secondary regulation. The MoF should issue detailed regulations regarding the budget classification and the chart of accounts for the government. It should also determine government accounting standards.

The budget system law should set a standard of transparency for budget reporting (frequency, content). For instance, it should specify that all budget organizations have to prepare monthly reports on the execution of the budget: these reports are consolidated by the MoF and presented to the cabinet. The government should provide quarterly reports on the execution of the budget to the legislature and to the public.

All budget organizations must provide annual accounts, which should be consolidated by the MoF. The MoF has to submit the draft final accounts to the audit office and the cabinet. In turn, the cabinet should be required to provide audited final accounts to the legislature within six months of the following year and the accounts should be reviewed and approved by the legislature. The government should be committed to act on the auditor's remarks.

\section{Control and Audit}

To ensure proper incentives for proper financial management, the heads of budget organizations should be responsible for ensuring that budget 
resources are used in accordance with the decisions of the legislature and superior budget organizations. Each budget organization should have a chief financial officer, who ensures that budget management is done in accordance with applicable rules, regulations, and good practices. The heads of budget organizations and chief financial officers are jointly responsible for establishing appropriate internal control mechanisms within their organizations and areas of responsibility.

All budget transactions should be jointly authorized by the head of the budget organization and the chief financial officer, or by officials designated by them. Delegation of authority should be clearly documented, and does not relieve the head of the budget organization and the chief financial officer of their primary responsibilities.

The MoF should assist budget organizations in designing control mechanisms and in implementing internal control and internal audit. For this purpose, the MoF may post budget officers in all ministries and major agencies.

Execution of the budget is usually subject to audit by an external (parliamentary) audit office. This office audits the financial and operational performance of the government, audits and certifies the final government accounts, and must submit an annual report to the legislature within six months of the following budget year. All budget programs should be subject to regular evaluation, to ensure that the intended objectives are realized as efficiently as possible.

Heads of budget organizations and chief financial officers that fail to comply with these requirements should be subject to administrative sanctions in accordance with applicable law (civil law or regulation of the civil service) and in severe cases of mismanagement to criminal prosecution.

\section{Budget Relationships with Municipal Administrations}

It is important that relevant provisions of the budget system law apply to subnational governments and municipalities. ${ }^{1}$ For instance, no municipality should raise loans or issue guarantees without authorization in the annual budget law or in separate law. The transfers that municipalities may receive from the central government budget must be prepared by the cabinet during the same budget formulation process. Proposals for transfers to municipalities should be submitted (via the Ministry of Interior and Ministry of Finance) at the same time and in the same format as the ministries submit their budget proposals, and made subject to similar review, decision, and appropriation procedures as other budget expenditures. Municipalities should also provide budget execution reports, as well as annual accounts-and be subject to control and audit by state control and audit bodies, including the external audit office. 


\section{Budget Relationships with State-Owned Enterprises}

Similarly, the budget system law should provide references to applicable other laws for the relationship with state-owned enterprises (SOEs). The budgetary relationships between the government and SOEs can be regulated by the provisions in this law or in a separate law.

The budget system law would generally focus on broad principles. For instance, that the government may make payments to state-owned enterprises, and receive dividends, loan repayments, and other payments from these enterprises; but any such payment must be clearly identified in the government budget. In addition, any payment or loans by the government to an SOE should be done by the MoF; and any payment of dividends, loan repayments, or other non-tax payments from an SOE should go to the MoF. For the purpose of tax collection, SOEs should be treated as any commercial company. The sector ministries should play no role in tax collection.

SOEs should provide quarterly financial statements to the MoF and the sector ministry, as well as annual accounts. SOEs are subject to control and audit by state control and audit bodies, including the central audit office.

\section{The Current Budget law}

The current Afghan Budget Law was enacted in 1970s and drafted based on a Soviet-style system. While the law is concise and broadly addresses issues of concern to government financial management, in most respects the current law is unsuited to support modern financial management and deficient in a number of key areas. The main weaknesses in the current Budget Law are the following:

- The law does not reflect the current institutional structure of Afghanistan, with frequent references to the Revolutionary Council as the budget appropriation and amendment institution.

- The law does not reflect the current budget structure. It is divided into central and rural budget, development budget, social welfare budget, and confidential budget. Major parts of the law are related to procedures for preparing and implementing budget sections that no longer exist.

- The law fails to set out a clear and transparent budget classification structure consistent with international standards and practices.

- The law prescribes a Soviet-style budget preparation procedure, based on indices in the five-year development plan, and detailed input cost norms.

- The law does not require the budget to be based on a medium-term macroeconomic framework, and does not specify which documents and parameters should be included in the budget proposal to the parliament. 
- The law attempts to provide strict guidelines for budget execution. It prohibits nonbudgeted expenditures and arrears, and requires funding to go through a central revenue account. However, these provisions are often unclear, and are insufficient to ensure full MoF control.

- The law fails to distinguish between government budget organizations and other institutions in the budget preparation and execution process.

- The law fails to establish a clear separation between the revenue collection and treasury management functions of the government.

- The law fails to establish a consistent framework for internal control, internal audit, and external audit.

- The law does not include any provisions for financing of the budget, guarantees, or other below-the-line operations.

- The law does not address tax expenditures, and therefore does not establish any direct controls on ministries or codified process for tax expenditures.

- The law is very difficult to read and interpret. It contains many repetitions, inconsistencies, and ambiguities, and certain technical terms seem to be used incorrectly.

While the current budget system law has not been formally suspended, many provisions are not actively enforced pending the introduction of the new PEFM law. In addition, a number of key deficiencies have been addressed through the annual budget decree.

\section{A New Budget System Law}

The fundamental objective of a budget system law is to improve governance. It should contribute to ensuring the transparency, stability, predictability, quality, and credibility of the budget management process. All budget system laws aim to clarify the relative responsibilities and the relationships between the different arms of government, in particular between the legislature and the executive, as well as between the government and other major sectors of society. In some countries, the scope of the budget system law is limited to resolving these issues. Other countries also want the law to specify the broad parameters of the main budget management procedures, and to reflect and provide responses to the major budget management challenges that the government is facing. Transition economies and other countries undergoing significant changes in financial management often prefer the latter approach.

\section{Legal Framework of the Budget System Law}

The legal framework for the budget is usually made of three main interrelated elements: the Constitution, a budget system law, and secondary 
regulation. The use of one legal instrument instead of the other is based on a tradeoff between the constraints to change provisions set by higherlevel laws and the flexibility provided by a lower level of regulation (see table 7). The approach adopted in Afghanistan is to set out the principles and core legal requirements of financial management in the draft PEFM law, with the specific details set out in regulations and instructions to give full effect to the provisions of the law.

Table 8 gives an overview of the draft PEFM law. The law was drafted based on a generic set of principles for a budget system law. The law commences by stating the broad principles that underline the budget, including defining the responsibilities of key government positions responsible for financial management. Key elements of the budget cycle (formulation, execution, reporting, control, and audit) are specified, including the fiscal relationship with municipalities and state-owned enterprises. The sections below describe the main elements of a budget systems law.

Many countries have found it beneficial to include key provisions for budget management in their Constitution, in particular fundamental principles for good budgeting. Examples of these include the principle that revenues, expenditures, loans, and guarantees must be authorized by a law, that all revenues and expenses should be managed with a general or consolidated fund, that there should be an annual budget, including all government expenses in gross terms, and that the budget, its formulation, execution, and auditing, should be transparent.

The budget management provisions included in the Afghanistan Constitution are limited and focus on mechanisms for approval of the budget, funding mechanism if the budget is not approved prior to the commencement of the financial year, approvals of grants and loans and provision of accounts within six months of the end of the financial year. Consequently, the draft PEFM law expands on these key provisions to set out a broad public expenditure and financial management framework.

\section{Enforcement of the Law}

For a budget law to be effective, it must be enforced in a consistent manner. The provisions in the law must be clear and unambiguous, and be perceived as realistic and reasonable. The same applies to secondary regulations and instructions under the law, as well as for the administrative decisions that $\mathrm{MoF}$ takes in the implementation of the law. Efforts in these areas will probably have the most effect on the budget organizations' compliance with the law.

The draft PEFM law includes penalties for noncompliance. These are intended as a measure to promote compliance with a law and would 


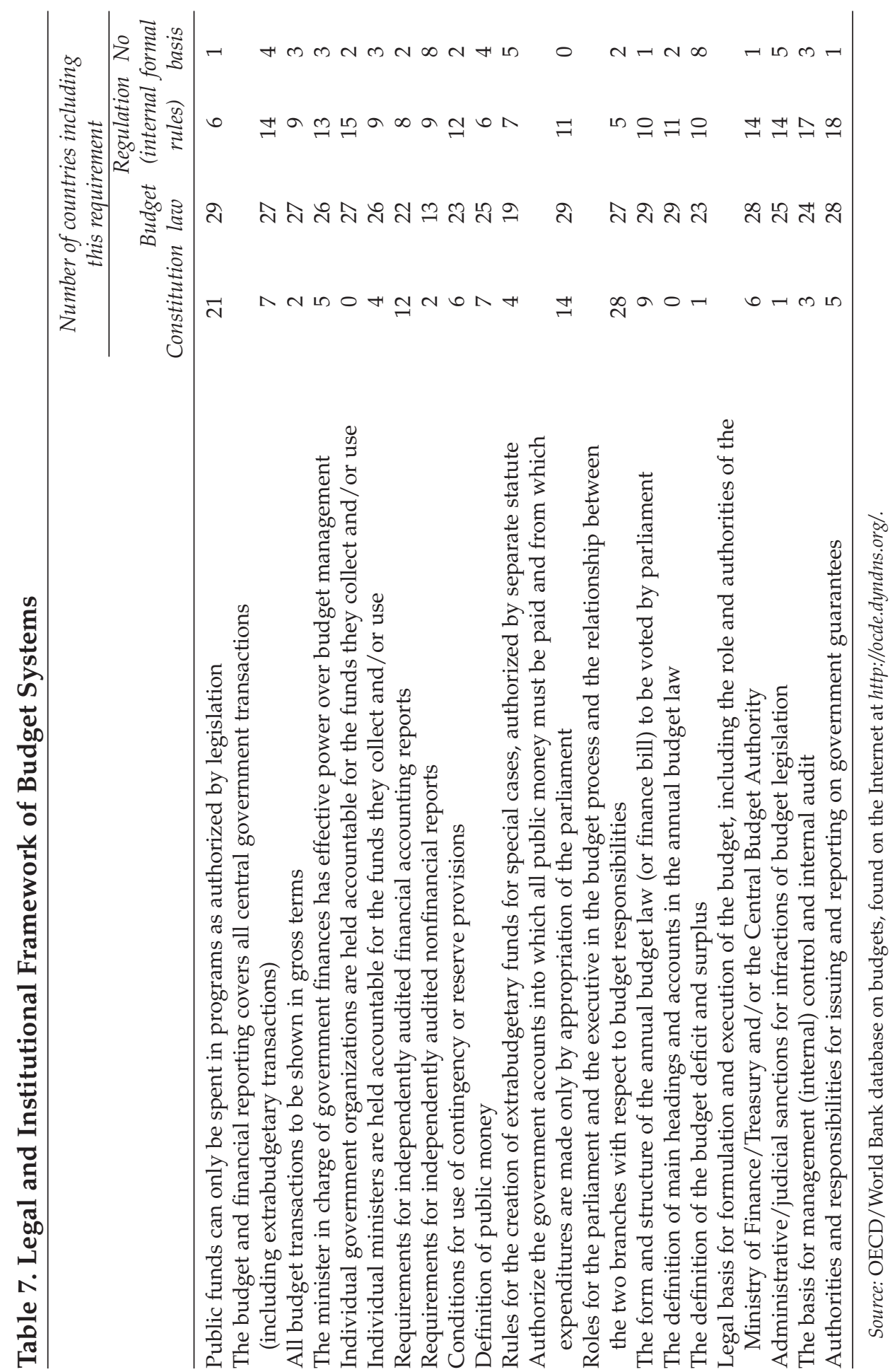




\section{Table 8. Structure of the Public Expenditure and Financial} Management Law for Afghanistan

\begin{tabular}{|c|c|c|}
\hline Section & & Key provisions \\
\hline I & Definitions & Definition of terms and expressions. \\
\hline II & $\begin{array}{l}\text { General } \\
\text { provisions }\end{array}$ & $\begin{array}{l}\text { - Law covers all government budget operations. } \\
\text { - Law cannot be amended or suspended through sepa- } \\
\text { rate law. } \\
\text { - Representation of revenues and expenditures on gross } \\
\text { basis. } \\
\text { - Responsibilities of key government positions responsi- } \\
\text { ble for financial management. } \\
\text { - Head of budget organizations accountable for use of } \\
\text { budget funds. } \\
\text { - Chief financial officer accountable for compliance with } \\
\text { regulation. } \\
\text { - All funds to be held in the treasury single account. } \\
\text { - Defines "public money" and authorization of receipt } \\
\text { or expenditure of public money. } \\
\text { - Operation of bank accounts. } \\
\text { - Prohibits loans or guarantees without authorization in } \\
\text { law. } \\
\text { - All budget revenues accrue to the general fund. } \\
\text { - Requires specific budget classification. } \\
\text { - Budget covers all government entities and operations. } \\
\text { - Authorizes cabinet and MoF to issue secondary regu- } \\
\text { lations. } \\
\text { - Implementation of public service payroll. } \\
\text { - Budget relations with municipal administration. }\end{array}$ \\
\hline III & $\begin{array}{l}\text { Preparation } \\
\text { and contents } \\
\text { of the annual } \\
\text { budget and } \\
\text { budget laws }\end{array}$ & $\begin{array}{l}\text { - Budget based on macroeconomic framework and } \\
\text { national development program. } \\
\text { - Cabinet determines overall and sector ceilings. } \\
\text { - Ministry budget proposals must be within sector } \\
\text { ceilings. } \\
\text { - Contents of budget, appropriations, and government } \\
\text { finances law. } \\
\text { - Review of budget } \\
\text { - Special funds budget. } \\
\text { - Budget proposal to Wolesa Jirga two months before } \\
\text { fiscal year. } \\
\text { - Provisions for late approval. }\end{array}$ \\
\hline IV & $\begin{array}{l}\text { Revised and } \\
\text { supplementary } \\
\text { budgets and } \\
\text { appropriations } \\
\text { laws }\end{array}$ & $\begin{array}{l}\text { - Provision for midyear budget review and appropria- } \\
\text { tions. } \\
\text { - Budgetary implications of new legislation must be } \\
\text { covered by amendments. }\end{array}$ \\
\hline
\end{tabular}


Table 8. (continued)

\begin{tabular}{|c|c|c|}
\hline Section & & Key provisions \\
\hline V & $\begin{array}{l}\text { Rules about } \\
\text { appropriations }\end{array}$ & $\begin{array}{l}\text { - Lapsing of appropriations. } \\
\text { - Contingent expenditures. } \\
\text { - Adjustments to appropriations. }\end{array}$ \\
\hline VI & $\begin{array}{l}\text { Expenditure of } \\
\text { appropriated } \\
\text { public money }\end{array}$ & $\begin{array}{l}\text { - MoF to issue allotments. } \\
\text { - Rules about allotments. } \\
\text { - MoF approval of budget commitments and payments. } \\
\text { - MoF can reduce commitments and payment when } \\
\text { cash shortages occur. } \\
\text { - Prohibition of offsetting and netting arrangements. } \\
\text { - Budget funds lapse at year-end. }\end{array}$ \\
\hline VII & $\begin{array}{l}\text { Reporting, } \\
\text { accounting, } \\
\text { and audit }\end{array}$ & $\begin{array}{l}\text { - Publication of budget and appropriation law. } \\
\text { - MoF to determine classification, chart of accounts, and } \\
\text { accounting standards. } \\
\text { - Budgeting and accounting records. } \\
\text { - Quarterly progress reports on budget to President and } \\
\text { cabinet. } \\
\text { - Final report on the budget. } \\
\text { - Audited annual accounts to legislature within six } \\
\text { months. } \\
\text { - Joint responsibility for establishing internal control. } \\
\text { - Joint responsibility for authorizing financial } \\
\text { operations. } \\
\text { - Regular evaluation of all budget programs. } \\
\text { - MoF to provide internal audit; external audit by an } \\
\text { audit office. }\end{array}$ \\
\hline VIII & $\begin{array}{l}\text { State-owned } \\
\text { enterprises }\end{array}$ & $\begin{array}{l}\text { - Relationships regulated in law. } \\
\text { - Precedence of law with Central Bank. } \\
\text { - Capitalization of SOEs via an appropriation. } \\
\text { - Acquisition from SOEs at market value. } \\
\text { - Loans to SOEs. } \\
\text { - Accounting practices and reporting requirements. } \\
\text { - Independent audit. } \\
\text { - Subject to audit by state audit bodies. } \\
\text { - Responsible minister and Minster of Finance to be } \\
\text { informed. }\end{array}$ \\
\hline IX & $\begin{array}{l}\text { Accountability } \\
\text { and sanctions }\end{array}$ & $\begin{array}{l}\text { - Responsibility for budget implementation. } \\
\text { - Civil penalties for persons breaching provisions of law. }\end{array}$ \\
\hline
\end{tabular}


typically be used as a last resort. Where possible, sanctions are to be based on existing general legislation, such as a law on the rights and obligations of civil servants.

\section{Implementation of the New Budget System Law}

Many of the requirements and processes set out in the PEFM law are drawn from existing laws or codify financial management reforms being instituted by the government. Consequently, the task of implementing the PEFM law is broadly achievable in a 12-month timeframe based on the current implementation of the reform agenda.

Given the magnitude of reforms currently being implemented across the government, this will not be a trivial achievement and it will be important to link the reform processes. For instance, the PEFM law interrelates with reform to the Civil Service Law, reform of SOEs, establishment of a supreme auditor, and further rationalization of banking operations of ministries and provincial entities.

\section{Note}

1. Currently, the only subnational governments in Afghanistan are the municipalities, which have very limited responsibilities. The provinces are deconcentrated organs of the central government, and not a separate level of government. 


\section{7 \\ Fiscal Management for the Provincial Municipalities}

\section{Summary}

Afghanistan faces several serious development challenges at the subnational level. These include rampant urban growth and the formation of informal settlements, massive service delivery backlogs, land tenure confusion, and poor urban management. To illustrate: the urban population is growing at twice the rate of the general population; about half of urban residents in Kabul do not have secure land tenure as most are settled in unplanned areas; about 40 percent of urban roads are destroyed, there are only 31,500 piped water connections in Kabul, and skills to manage urban areas need to be updated after 30 years of war.

In spite of the central system of government in Afghanistan-under the 1964 Constitution, all local authorities fall under the Ministry of Interior (MoI), which controls and promulgates regulations and functions of local governments; all provincial governors and mayors fall under it, and it approves the local governments staffing and budgeting plans and expenditures-the municipalities do provide an opportunity to contribute to, and in some instances to directly manage, reconstruction work and service delivery.

This opportunity stems from the current allocation of functions, a degree of municipal budgeting and expenditure independence and a fairly coherent institutional structure.

However, several issues require attention to strengthen the capacity and focus of the municipalities. These include: (1) clarifying levels of autonomy and allowable municipal diversity, (2) clarifying functional responsibilities, (3) improving administrative structures within municipalities (with organizational and institutional restructuring), (4) improving expenditure management (expenditure and financial management

This chapter was prepared by Nick Manning and Soraya Goga. 
systems, civil service reform, etc.), and (5) moving toward a block-grant transfer system for the larger and more competent municipalities.

\section{Municipalities within the Larger Public Sector ${ }^{1}$}

There are four types of subnational administration in Afghanistan:

- 32 provinces (wolayat),

- Approximately 355 districts (uluswali)—with each province containing between 3 (the minimum) and 27 districts,

- Provincial municipalities (sharwali wolayat)—with each province, in principle, containing one such municipality, and

- Rural municipalities (sharwali uluswali)—with each district containing at most one rural municipality, but some with none.

As noted earlier, the current structure of government is unitary with all political authority vested in the government in Kabul. The powers and responsibilities of the provincial and district administrations are determined (and therefore may be withdrawn) by central government. Thus although provinces and districts are legally recognized units of subnational administration, they are not intended to be autonomous in their policy decisions other than through some flexibility in implementing centrally determined programs. However, some attempts have been made at establishing local participative bodies. Article 3, chapter 8 of the 2004 constitution specifies that a provincial council is to be formed in every province, with elected members.

Municipalities are distinctly different from districts and provinces. Municipalities are largely self-sustaining entities with responsibility for providing several services (such as trash collection, recreation, and park services) and collecting minor revenues from local service charges and retail licenses. Generally, there is one provincial or primary level municipality in each province, and some districts also have "district" or "rural" municipalities. Of the seven larger and more developed provinces, six have provincial municipalities that are recognized as having some distinctive capacity (Balkh-Mazar, Herat, Kabul, Kandahar, Kundoz, NangraharJalalabad). These provincial municipalities have populations in excess of 500,000 and between them they house about 72 percent of the urban population. However, of these six, only Kabul has a distinctive legal status (as a ministry) - the other provincial municipalities all have the same legal status whether they are large with significant capabilities or small in remote provinces.

A total of 217 municipalities in Afghanistan have populations of at least 5,000 . All municipalities require approval from the Ministry of Interior 
(MoI) for their budget (takhsis) and staffing (tashkeel), but beyond this are supposed to operate independently. In some provinces, however, the provincial municipality oversees or controls the actions of rural municipalities even to the extent that, in some cases, all revenues are turned over to the provincial municipality, which in turn pays all expenses.

Provincial municipalities are similar to provincial departments, in that they report — on budgeting and staffing mostly - to a parent ministry in Kabul (the Ministry of Interior). The MoI, via the governor, approves the municipality's budget (both operational and capital), organizational structure, and staffing numbers. However, they differ in that, historically, the budget is completely financed by a range of local revenues, which are established in regulation by the Ministry of Finance. They also differ in that budget planning and prioritization, at least at the level of the operational budget, is determined by the municipality, considering its current levels of income.

Municipalities have key development responsibilities, such as planning, wastewater management and flood protection, solid waste management, and construction and paving of roads. In cooperation with other government line ministries, they are also indirectly involved in the construction of the city sewerage system, water supply, city power, communications, public health, education, and sport. Public urban transport is controlled by the Ministry of Transport, while traffic management falls under the MoI.

However, several other functions that are not usually the function of a municipality are a legacy of the Soviet era. These include price controls and setting residential rents.

\section{Municipal Institutional Structures}

Structurally, a typical municipality is deconcentrated into geographical areas. At the local level, each area has a president and vice president, and below them are five offices, for: engineering; foodstuffs control; statistics; administration; and income, property, and sanitation. A construction valuation office and the construction control office fall under the engineering office.

Below the area level is a further division into gozars (neighborhoods), with distinct physical boundaries, each with a wakil-e-gozar (neighborhood level representative). Typically, about 15 to 20 gozars form a single area. In 1990, prior to the Mujahidin takeover in 1993, elections were held for community representatives to city councils, at area level, via mosques and collection centers. Since 1993, no elections have taken place.

Each area has a president (elected, in principle), or wakil, who sits on the area council. The head of the district consultative board becomes 
district president. The district president sits on the district council, which in turn reports to/consults with, the deputy mayors. During the Mujahidin period, a municipal law was passed that enabled community level candidates (including women and youth) to put themselves forward for election to area councils. The number of members of a district council varies with the size of the area. Representatives of the 15 gozars in Kabul combine to form an area council. A subcommittee of this elects a city council for Kabul with some 83 members.

\section{Fiscal Relationships}

The Ministry of Interior oversees municipalities (albeit with significant influence by the governor in some provinces). The Ministry of Interior in Kabul must sanction the staffing numbers and budget of each municipality, despite the fact that municipalities are entitled to collect and retain their own tax revenues. However, there is no accountability to any level of government on actual service delivery. Also no accountability to any community group is required on either service delivery or budget and expenditure-in spite of the area-based system. In some provinces, Herat and Kandahar being examples, rural municipalities also have a reporting relationship with the provincial municipality, as noted below.

\section{Fiscal autonomy}

Outside of central government, the municipal level is the only one with any measure of fiscal autonomy, and even then it is minimal. All tax and fee rates are set in Kabul, but the revenues do remain at the municipality level and fund all municipal expenditures.

In reality, the extent of municipal activity is significantly constrained by the resources available, in spite of considerable spending discretion, especially when surpluses are generated. In some of the provinces, this access to revenues gave significant authority and prestige to the local mayor, particularly in rural municipalities, where the local uluswal had no access to revenues whatsoever (Evans and others 2004a).

Rural municipalities exist where the village and tax base is large enough to warrant it. These smaller municipalities are supposed to have the same financial and reporting relations with the Ministry of Interior as the provincial municipality. However, the practice appears to vary substantially. In Badakhshan, rural municipalities do operate as described above. In Herat, on the other hand, there is a reporting relationship between the provincial municipality and the various rural municipalities. Here, the Herat City municipality approves the budget, staffing levels, and organizational structure for each of the rural municipalities. However, as with the provincial municipality, rural municipalities are 
financially self-sufficient. If they should run a surplus, by collecting more revenues than needed for their approved budget, they can hold this amount in their local bank account. Kandahar provides a third distinct model, which treats rural municipalities most closely like district subdepartments. For example, the municipality in the district of Panjwayee sends all of it revenues to the Kandahar municipality, and in turn, its employees receive their salaries from the Kandahar municipality. And Panjwayee municipality receives no non-salary allocation. Moreover, the Kandahar municipality is requiring the Panjwayee municipality to collect and remit Af 700,000 in 1382, up from the Af 20,000 collected in 1381. The only function of the Panjwayee municipality is revenue collection; it provides no local services whatsoever.

Kabul Municipality is somewhat of an anomaly in the system with a far greater independence than any of the other municipalities. It has the status of a ministry, which has a number of implications for its functioning. In particular, the mayor and senior staff are directly appointed by the President, seemingly with no involvement from the Ministry of Interior. Unlike the budgets of other municipalities, its budget is approved by the Ministry of Finance, and not the Ministry of Interior.

\section{Municipal revenues}

Sources of municipal revenue are varied, but they are all governed by the Legislation on Municipalities (15/10/1369, amended 1379). Rates for all taxes and fees collected by provincial municipalities are set in Kabul. However, revenues remain in the municipality and fund all municipal expenditures.

Revenues collected by rural municipalities are also supposed to remain in the municipality to fund local expenditures (but in some cases, they are in fact remitted to the provincial municipality).

The several diverse sources of revenue for Kabul include rental tax (one month of rent per year), safayi tax (a service charge and a property tax), market rental, business permissions, imports, 1 percent on profits of traders and business establishments, selling of municipal property, fines, documents, the Kabul zoo, income from cinemas and public bathrooms, and NGO tax (apparently collected in U.S. dollars). Table 9 provides a summary of revenues and expenditures for 1381 for six provincial municipalities.

\section{Budgeting and planning}

Because it must gear its budget to available revenues, the municipality is the only subnational administration that goes through any sort of budgetplanning process, beginning with estimating revenues, and then compiling a budget that fits within this constraint. This budget is then submitted to the Ministry of Interior for approval. However, this independent budgeting process focuses on the operating budget and not the development budget. 


\section{Table 9. Provincial Municipalities: Revenues and Expenditures} for 1381, in afghanis

\begin{tabular}{lrrrrrr}
\hline & & & & & & $\begin{array}{c}\text { Wardak } \\
\text { (Maidan } \\
\text { Badakhshan } \\
\text { (Faizabad) }\end{array}$ \\
\hline Revenues & 609,000 & 359,394 & $4,942,799$ & $30,287,448$ & $31,256,954$ & 186,753 \\
Expenditures & 552,000 & 132,048 & $4,030,008$ & $29,993,881$ & $20,579,158$ & 163,588 \\
Surplus/Deficit & 57,000 & 227,346 & 912,791 & 293,567 & $10,677,796$ & 23,165 \\
\hline
\end{tabular}

Source: Provincial municipalities in Evans and others (2004a, p.6).

The budgeting process for the operating budget is relatively simplebut is fairly top down. The Finance and Planning Department controls budgeting and planning. Each department submits to it its staff estimates (tashkeel) and its budget estimates (takhsis) in the eighth month of the year. The estimate is usually based on last year's budget plus an additional topup (about 10 percent). A covering letter from the head of the Department to Finance and Planning explains the needs for the increase. The budget is submitted to an administrative meeting of the municipality, which endorses it before it is sent to the Ministry of Interior for approval.

The planning for the development budget is not as autonomous as that of the operating budget. The development needs for the municipality are formulated by that level of government but funding is not guaranteed and the needs are more of a "shopping list." This list is passed on to the MoI, which then aggregates the needs of all the municipalities. This is passed on to the Ministry of Planning and then to the Ministry of Finance (MoF). The $\mathrm{MoF}$ then allocates an amount to the MoI-as it does with all ministries. The municipalities then apply to the MoI for that development expenditure. ${ }^{2}$

\section{Staffing Establishment}

At the municipal level, the tashkeel is approved by the MoI. However, the number of filled positions is dependent on the municipality's ability to raise adequate revenues. Available data on staff numbers in six provincial municipalities are shown in table 10. Although these data are incomplete, certainly in the cases of Faizabad, Bamyan, and Maidan Shahr lack of funding has had a significant impact on the number of staff. This situation is further exacerbated when the government in Kabul approves increases in pay, since municipal staff members are paid on the same pay scale as other public sector employees.

Staff are selected by the mayor but are officially appointed by the governor, Minister of Interior, or the president or cabinet, depending upon rank. Table 11 provides details. 
Larger municipalities with substantial public works projects have a significant number of daily paid employees. This is in contrast to other government bodies that employ very few such daily, paid staff.

Table 10. Provincial Municipalities: Staffing Structure for 1381

\begin{tabular}{lcc}
\hline & Positions dilled & Tashkeel \\
\hline Faizabad (Badakhshan) & 33 & 40 \\
Bamyan & 12 & 52 \\
Maimana (Faryab) & na & 54 \\
Herat City* & na & 547 \\
Kandahar City & na & 524 \\
Maidan Shahr (Wardak)* & 17 & 46 \\
\hline
\end{tabular}

* For 1382.

Source: Provincial municipalities in Evans and others (2004a, p. 6).

\section{Table 11. Employment Authorities for Staff}

\begin{tabular}{lll}
\hline Karmand grade & \multicolumn{1}{c}{ Selection } & Appointment \\
"beyond" & $\begin{array}{l}\text { Urban mayor } \\
\text { (for rural municipality) } \\
\text { or governor }\end{array}$ & President \\
2 & Mayor or governor & Minister of Interior \\
\hline 3 & & \\
4 & & \\
5 & Mayor or governor & Governor \\
\hline 6 & & \\
7 & & \\
8 & & \\
9 & & \\
10 & & \\
\hline Agir Grade & Mayor, governor, & \\
\hline "beyond" & or minister & \\
\hline 1 & Mayor or & Minister of Interior \\
2 & governor & \\
\hline 3 & Mayor & \\
4 & & \\
5 & & \\
\hline
\end{tabular}




\section{Voting and Participation}

Before the Soviet occupation, mayors were directly elected. Now, mayors of provincial municipalities are appointed by the Ministry of Interior, subject to presidential approval. The Ministry of Interior does not seek any recommendation from the governor. In Kabul municipality, the mayor is directly appointed by the president.

Mayors are advised by municipal councils. Article 111 of the 1964 Constitution indicated that municipal councils are to be established by "free, universal, direct, secret election." However, there have been no elections to the city council since 1992. Article 6, chapter 8 of the 2004 constitution notes that municipalities shall be established to administer city affairs.

There are also advisory or administrative councils that bring together heads of the various zones into which the larger cities are divided, including municipal department heads, the mayor, and the deputy mayor. They are presided over by the governor.

\section{The Future Role of Municipalities in Implementation}

The budgetary, revenue generation, and expenditure control independence, coupled with the municipal functional allocation and existing municipal departments and staffing, form a good basis for the role of the municipality as a service provider and implementing agency. However, several issues will have to be addressed if municipalities are to be developed as implementing entities:

- clarifying levels of autonomy and allowable municipal diversity,

- clarifying functional responsibilities,

- improving administrative structures within municipalities, and

- improving expenditure management.

\section{Levels of Autonomy - Clarifying Municipal Diversity}

In Afghanistan, as elsewhere, not all municipalities are equal. ${ }^{3}$

RURAL MUNICIPALITIES are rarely independent and, as noted above, appear to fall into three broad categories:

- autonomous bodies with a similar status to provincial municipalities,

- bodies under the tutelage of the provincial municipality, and

- bodies under the tutelage of the district (akin to district subdepartments).

PROVINCIAL MUNICIPALITIES differ primarily according to their size and status. Table 12 shows details of the provinces and districts according to grade. The 
grade is determined largely by population, but additional political factors play into the assignation. Grade 1 is the largest and grade 3 is the smallest. The grade of a province or district will affect the size of governor's office and district office, as well as the position grades of the staff.

Table 12. District Administrations by Province

\begin{tabular}{|c|c|c|c|c|c|}
\hline \multirow[b]{2}{*}{ Province } & \multirow{2}{*}{$\begin{array}{l}\text { Provincial } \\
\text { grade }\end{array}$} & \multicolumn{3}{|c|}{ Number of districts } & \multirow{2}{*}{$\begin{array}{c}\text { Total } \\
\text { number of } \\
\text { districts }\end{array}$} \\
\hline & & Grade 1 & Grade 2 & Grade 3 & \\
\hline Kabul & 1 & 4 & 5 & 5 & 14 \\
\hline Nangrahar & 1 & 5 & 13 & 3 & 21 \\
\hline Badakhshan & 1 & 1 & 15 & 11 & 27 \\
\hline Kundoz & 1 & 3 & 3 & 0 & 6 \\
\hline Balkh & 1 & 5 & 9 & 0 & 14 \\
\hline Heratt & 1 & 5 & 7 & 3 & 15 \\
\hline Kandahar & 1 & 2 & 9 & 4 & 15 \\
\hline Kapisa & 2 & 4 & 1 & 1 & 6 \\
\hline Parwan & 2 & 3 & 7 & 3 & 13 \\
\hline Ghazni & 2 & 5 & 6 & 7 & 18 \\
\hline Paktiya & 2 & 2 & 6 & 2 & 10 \\
\hline Takhar & 2 & 3 & 6 & 7 & 16 \\
\hline Baghlan & 2 & 2 & 6 & 6 & 14 \\
\hline Jawzjan & 2 & 1 & 2 & 6 & 9 \\
\hline Faryab & 2 & 5 & 5 & 3 & 13 \\
\hline Farah & 2 & 0 & 8 & 2 & 10 \\
\hline Helmand & 2 & 3 & 7 & 2 & 12 \\
\hline Wardak & 3 & 2 & 4 & 2 & 8 \\
\hline Logar & 3 & 0 & 4 & 2 & 6 \\
\hline Laghman & 3 & 1 & 2 & 1 & 4 \\
\hline Kunar & 3 & 0 & 4 & 10 & 14 \\
\hline Smangan & 3 & 2 & 2 & 2 & 6 \\
\hline Badghis & 3 & 1 & 5 & 0 & 6 \\
\hline Nimroz & 3 & 0 & 4 & 0 & 4 \\
\hline Zabul & 3 & 0 & 5 & 4 & 9 \\
\hline Oruzgan & 3 & 2 & 6 & 0 & 8 \\
\hline Ghor & 3 & 1 & 4 & 4 & 9 \\
\hline Bamyan & 3 & 2 & 2 & 2 & 6 \\
\hline Paktika & 3 & 0 & 5 & 13 & 18 \\
\hline Nuristan & 3 & 0 & 2 & 5 & 7 \\
\hline Saripul & 3 & 1 & 3 & 1 & 5 \\
\hline Khost & 3 & 0 & 5 & 7 & 12 \\
\hline Totals & & 65 & 172 & 118 & 355 \\
\hline
\end{tabular}

Provinces in italics are those with a comparatively high capacity provincial municipality. Source: Ministry of Interior. 
Table 13 illustrates the formal fiscal and administrative distinctions between provincial and rural municipalities-but in practice the arrangements vary significantly.

Currently widely differing views on the accountability relationship of rural municipalities are held from one province to another, despite the fact that their independence is clearly set out in legislation. Clarifying and formalizing the distinction between rural and provincial municipalities would provide some much needed clarity on reporting and accountability relationships. Clarifying any formal distinctions between larger provincial municipalities and others would also be of value as currently, with the exception of Kabul and its distinctive status as a ministry, no legal or formal distinction exists between the larger provincial municipalities found in the category 1 provinces and others.

\section{Clarifying Functional Responsibilities and Structures}

As noted, the permissible functions of provincial municipalities are provided for in legislation. This makes municipalities key to development in several sectors, including road construction and solid waste management. However, in practice, some key functions appear not to be undertaken by municipalities (for example, upgrading and housing) and there is extensive jurisdictional confusion in relation to municipalities and government departments (for example, planning). Some functions that municipalities appear to consider their responsibility are undoubtedly legacies of the Soviet central planning era (for example, price control and land distribution).

These functions need review and some updating, not least to reflect the current challenges in urban administration, including rampant urban growth and the formation of informal settlements and land tenure confusion. The urban population is growing at twice the rate of the general population, and about half of urban residents in Kabul do not have secure land tenure as most are settled in unplanned areas.

The provincial municipalities all have departments relevant to their current legal functions, but this seems to leave some major urban challenges unaddressed. Housing, new settlements, and informal settlement issues do not have a natural "home" within the existing departmental structures; neither do issues of urban land tenure. Some reengineering of the municipalities' structures is crucial to ensure that form follows function.

\section{Improving Expenditure Management}

\section{Budget preparation}

Provincial municipality budget planning appears reasonable, but extends only to the operating budget. This system should be extended to the 


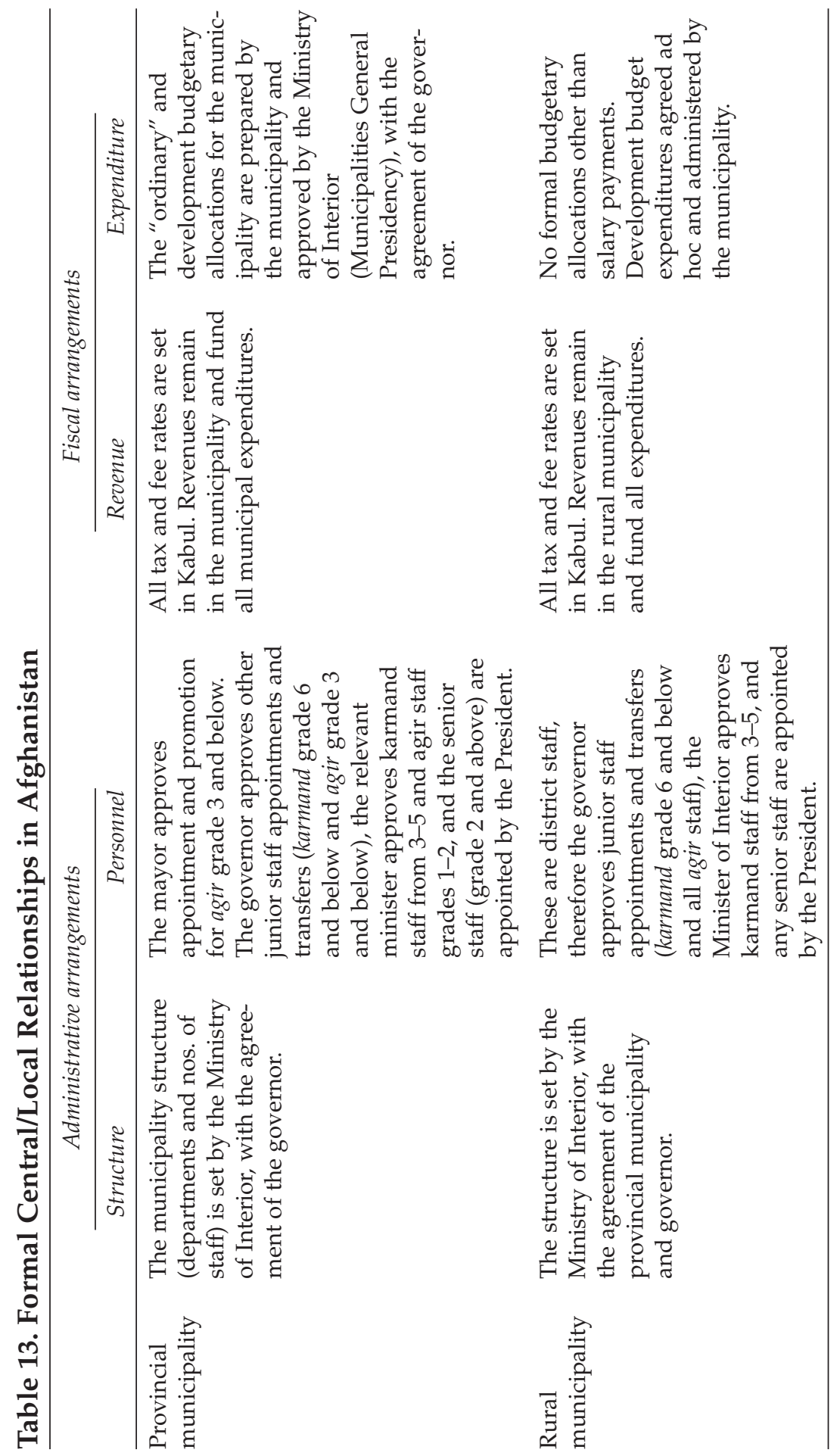




\section{Box 9. Organizational Restructuring Needed in Kabul Municipality}

Work Organization: Kabul Municipal Department of Sanitation (DoS) falls under the Department of Urban Services. It has more than 60 employees and about 1,300 contract staff, all Afghans, equivalent to about 4.5 employees/workers per 10,000 persons. The average salary for an employee is about Af 2,300/month (equivalent to $\$ 48 /$ mo.).

The Department of Sanitation owns a small fleet of solid waste collection vehicles, in addition to a couple of water trucks and earthmoving equipment. It also has a substantial space in which to work.

Waste collection by Kabul Municipality is ad hoc. No specific routing plan is assigned to each of the 40 vehicles and crew belonging to the municipality. Furthermore, the existing collection vehicles are small in size (3-5 cubic meter capacity) and drivers currently conduct only two trips per day. In the most accessible and visible parts of Kabul, waste is collected once a week. In other parts of the city, where streets are narrow and generally unpaved, the frequency of collection drops as low as once a month.

Skill Development: The construction unit in Kabul municipality is responsible for building canals and ditches, flood-protection measures, and constructing and paving roads. However, it appears to focus mainly on roads. The skills in the construction unit are poor. Although several employees are referred to as "engineer," several of them are technicians rather than qualified engineers. Skills have not been kept updated and the engineers' skills are likened to university graduate +2 years.

Changing Mindsets: The architecture and planning unit is responsible for the implementation of the master plan, and the design of buildings. According to a presidential decree, the Ministry of Urban Development and Housing is responsible for the formulation of the city plan, with the municipality responsible for its implementation. There is considerable uncertainty about the respective roles of the municipality and the province.

development budget, and should occur in a way to take into account development needs of communities. The budget is prepared based on inputs from line departments, but is submitted to the Ministry of Interior for approval as a consolidated budget, covering salaries and non-salary operating and maintenance expenditures.

The development budget is formulated as elsewhere in government. Municipalities, in consultation with the relevant line departments, make 
bids for inclusion in lists of sector-specific proposals for funding-which are approved by the Ministry of Finance and largely donor funded.

\section{Expenditure controls}

Expenditure control systems exist and records appear to be fairly well maintained. These systems are paper based and inefficient but can be improved quite simply. An often-cited concern is that the fiduciary risks of using the government's processes are too great, and too much money is likely to disappear. While these risks certainly exist, as shown in table 14, some basic systems are already in place, particularly for preapproval and preaudit, which will reduce the extent of the risk.

In addition to fiduciary risks, other risks could result in the misallocation of funds channeled through the ordinary budget. In particular, poor revenue forecasting at the municipal level could lead to the approval of expenditure budgets that are not realistic. In such a case, cash rationing could lead to priority programs not being funded. Doubtless much still needs to be done to improve these systems.

\section{Revenue incentives}

Provincial and other municipalities do collect revenues; and in several cities these are reasonably substantial. However, some improvements can occur, and policy decisions are required to improve cost recovery. First, the tax rates require review. For example, the valuation of property for the safayi tax last occurred in 1978. The highest charge on this tax is currently the equivalent of $\$ 4$. Second, tax administration is onerous. For the taxpayer it involves several visits to several departments. Third, the municipalities have no right of enforcement over nonpayment. This rests with the Ministry of Interior.

\section{Table 14. Sources of, and Means of Reducing, Fiduciary Risk}

\begin{tabular}{ll}
\hline Source of risk & Risk mitigation measures in place \\
\hline - Procurement procedures weak & - Municipal spending cannot exceed \\
or nonexistent & revenues as there are no other sources \\
- Cash payments are subject to & of funds \\
rent-seeking by intermediaries & - Detailed procurement procedures do \\
- Audit procedures do not exist & exist, with points of authorization and \\
or fail to report improprieties & preaudit, multiple bid requirements \\
- Program funds are used for & - The tashkeel system deters overhiring. \\
salaries in order to make & - Administrative councils provide addi- \\
patronage-based hires & tional accountability for staff. \\
\hline
\end{tabular}

Source: Evans and others (2004a). 


\section{A Strategy for Extending the Role of Afghanistan Municipalities in Reconstruction}

\section{Give Municipalities Some Basic Immediate Assistance from Kabul}

\section{Clarify the distinctive role of provincial municipalities}

The provincial municipalities in the grade 1 provinces offer a credible basis on which to scale up local project implementation. Rural municipalities do not. Provincial municipalities in the grade 2 and 3 provinces fall somewhere between the two. Government should clarify the functional responsibilities and accountability arrangements for all of the municipalities. Municipalities represent the only subnational level of more or less autonomous government in Afghanistan. Cautiously reasserting municipal autonomy, with a careful strategy of disentangling the lines of accountability (district municipalities should not be reporting through provincial municipalities) and specifying service expectations for municipalities with differing revenue raising capacities, could offer a promising vehicle for scaling up local services.

\section{Make technical assistance available}

Key technical assistance areas include:

- Municipal financial management to improve revenue generation capacity, expenditure management and budgeting frameworks of municipalities.

- Urban planning to formulate town planning policy, regulations, and guidelines.

- Service delivery arrangements, particularly for: services to informal areas, options for planning and land use, urban land management and land titling, local public administration and civil service reform; municipal functions and independence; and housing policy and strategies for creating new settlements.

- Institutional changes to ensure that the structure of the municipalities and the Ministry of Urban Development and Housing (MUDH) is commensurate with their functions.

- The absence of procedures can be resolved at minimal cost through the development of procedural manuals and training programs for staff in key provincial and district positions.

Further pay and pension reform

Municipal employees are paid on the same scales as other public sector employees. Current salary levels present a serious problem across the public sector. No labor market surveys exist to provide any robust 
comparators; but there is every reason to assume that at the higher levels of the civil service, and in skilled professional areas, salaries are insufficient to attract or retain qualified and competent staff. This was particularly the case when many government staff were being recruited by donors and nongovernmental organizations (NGOs), although arguably, the worst of this phenomenon is already over since many of the best staff have already left government service. Most immediately, a labor market survey is essential to improve the quality of the debate on potential pay raises for staff, and to provide a rational basis for planning. Any meaningful further salary decompression will first have to remove many anomalies through a comprehensive job evaluation and regrading exercise.

Provide funds for basic reconstruction of municipal buildings

The authority and standing of provincial municipalities can be bolstered by making funds available for basic provincial office reconstruction. Physical reconstruction requires the provision of a basic package of office facilities required to meet minimal performance expectations of provincial municipalities. The package should include radio and fax for the mayor and basic facilities for all staff. Major investment expenditures are necessary to provide adequate office facilities, particularly for district staff; some initial piloting is already planned. Once provinces and districts are meeting certain performance expectations, a second, more advanced set of improvements could be provided. The performance expectations could include establishing a good record of timely reporting of expenditures, revenues, and payroll.

\section{Block Grants-But with Conditions}

Municipalities come closest to an independent level of government. So, while it is, broadly, inappropriate to provide significant unprogrammed funds to the provincial level, as there is no provincial budget, this is not the case at the municipal level. There is a clear budget process with some significant degree of autonomy for the municipalities. If this is to be a genuine, albeit very tentative step, toward a developed system of intergovernmental transfers, it is important that funds transferred are fully on budget.

Consequently it is a reasonable strategy to provide grants to provincial municipalities - conditioned only on a list of permitted expenditure objectives and with no intention that the funds should lapse at the end of the year. Incentives can be established by providing nonlapsing conditional grants in subsequent periods, with the conditions, in essence, requiring that the preceding grant was expended only within the permissive list. Likely priorities reflected in the permissive list would be labor- 
intensive works, local roads, water and sanitation, and reconstruction of the municipality's own buildings.

Only provincial municipalities should be considered for a major program of investment in the short and medium terms. The rural municipalities are a very mixed bag and are generally very weak. Among other difficulties, the accountability relationships of rural municipalities vary significantly from one province to another, although their independence is clearly set out in legislation. In the longer term it will be important to disentangle the lines of accountability (rural municipalities should not be reporting through provincial municipalities) and to specify service expectations for municipalities with differing revenue-raising capacities. However, the challenges of building capacity at this rural level are so great that there is little advantage in considering them as part of the more immediate strategy.

Easily measurable indicators could be used to distinguish levels of administrative effort in provincial municipalities. Criteria for accessing modest additional funding could include:

- Three-month record of monthly expenditure reports submitted within one month of the end of the period, and

- Three-month record of monthly revenue reports submitted within one month of the end of the period.

Criteria for more substantial funding could include:

- Accuracy of financial reports, as evidenced by an audit review, and

- Existence of basic financial control procedures, as evidenced by an audit review.

\section{Notes}

1. See Evans and others (2004a) for further details of subnational fiscal and administrative structures.

2. In practice, currently, municipalities do not receive development expenditures. The development budget of the Islamic Republic of Afghanistan is largely provided by donors.

3. In all countries, municipal independence is qualified, and in many countries, several categories of municipalities are present. This is often based on population size, city GDP, etc. 


\section{8 \\ Next Steps in Reforming the Ministry of Finance}

\section{Introduction}

Like almost all of the bureaucracy in Afghanistan, the Ministry of Finance $(\mathrm{MoF})$ had suffered from 23 years of neglect during the period following the Soviet invasion. This manifested itself in chronic underinvestment in human and physical capital. At the start of 2002, there were no computers in the ministry-the deputy minister in charge of the budget department provided hand-held calculators to line ministry staff to use when preparing their handwritten budget submissions. The treasury system operated a manual ledger system, so no meaningful reconciliation was ever undertaken. Most significantly, the regular recourse to overdraft financing from the Central Bank meant that there was actually no need to keep an accurate accounting of funds or to program with any degree of precision.

Anecdotal evidence suggests that the vast majority of the budget was actually not programmed in any conventional sense; rather it was kept in discretionary funds that were allocated by the finance ministry or the President's Office. This provided considerable scope for corruption and, in July 2002, operations of the finance ministry were reportedly under the control of three significant criminal gangs. Senior positions with access to major revenue sources were said to be bought and sold.

The physical premises of the Ministry of Finance (MoF) were very poor, with broken windows, poorly functioning electrical systems, and a malfunctioning heating system. However, the central ministry building was in better condition than almost all of the provincial MoF buildings. Communications between the provinces and Kabul took weeks and in some cases months.

This chapter was prepared by Michael Carnahan with additional material from Nick Manning. 
The Ministry of Finance of Afghanistan has embarked on a program of comprehensive institutional renewal. This paper outlines the vision that the ministry has set out concerning its desired competencies, and how it should be structured to achieve them. The first section outlines the core business of the ministry. The second section maps these onto work units, providing the organizational structure being introduced to ensure that key tasks are achieved. It also notes that some tasks that are not the core business of a finance ministry must in fact be performed by the Ministry of Finance in Afghanistan, on a transitional basis. The third section outlines functions that should not be located in a finance ministry at all. The final section reviews the key transitional issues and priorities that are guiding the restructuring of the Ministry of Finance in Afghanistan.

\section{Developing Consensus on the Core Business}

Two key features define the fiscal environment. On the one hand, the domestic technical capacity is low, and there is limited understanding of current approaches to budgeting. On the other, there are proportionately large amounts of international technical assistance, much of which is remarkably ill-informed about budgeting and financial management within government. To deal with these constraining realities, the first task of the Ministry of Finance has been to lay the foundations for reform by negotiating with counterparts in government and in donor agencies to build some consensus on the core tasks facing the ministry.

The Ministry of Finance has argued that its core business is the management of the government's finances throughout the budget cycle, which includes planning, implementation, and reporting on the raising and spending of public revenues. However, to manage expenditure effectively for any particular budget year requires looking at a period of at least two years. The key components in a budget cycle are presented in figure 4 .

\section{Estimating the Available Resources}

Estimating domestic revenue has three distinct components. The first component is to analyze revenue collection data to determine how much revenue would be available if there were no changes in the parameters that drive it. The second component is to estimate the changes in those parameters through a macroeconomic model, for example, GDP growth, import growth, consumption growth, and employment growth. Based on these changed parameters, an estimate for revenue is constructed. The third component is to prepare a suite of revenue policy and administration options for consideration by the government in the context of prepar- 


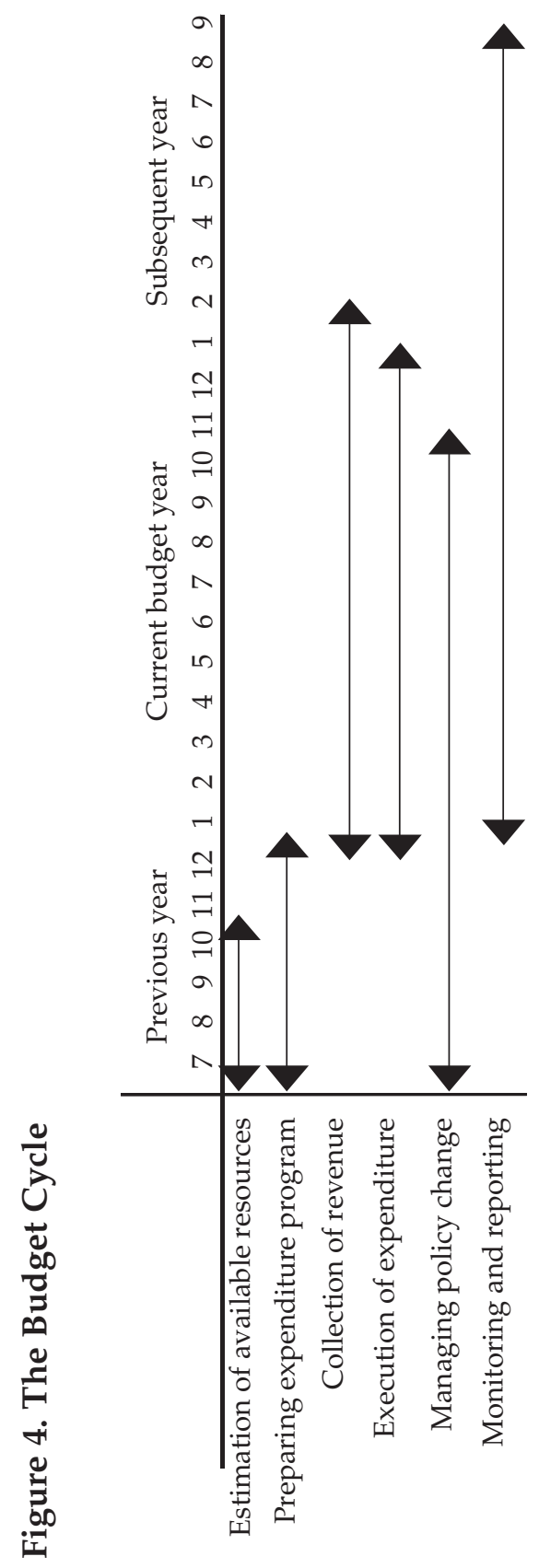


ing the budget. This includes policies for personal and corporate income taxation, consumption taxation, customs and excise taxation, and resource taxation. All this work is best undertaken in a dedicated economic or macroeconomic policy unit within the Ministry of Finance.

Estimating the resources likely to be available from donors is a perennial challenge, and requires extensive liaison from a dedicated external relations unit. This includes resources made available both bilaterally and through multilateral mechanisms. The degree of fungibility around these resources varies-from a donor funding a specific project and implementing that project, to the donor funding a government project, through to the donor funding a government program, and ultimately to the donor funding the government budget.

The estimation of resources from external sources is complicated by the fact that the Ministry of Finance must wear two hats. In dealing with donors, the MoF must be an advocate for additional resources to meet expenditure needs. With the rest of government, the ministry has a role as the manager of these resources. The first responsibility leads the ministry to argue for an expansionary fiscal stance, the second requires it to argue for the reverse.

\section{Preparing the Expenditure Program}

Mindful of the available resources, the second core task of the Ministry of Finance is to prepare the annual budget for the approval of the legislature, noting that this is, as yet, theory rather than practice in Afghanistan. In a country such as Afghanistan, where the executive branch of government prepares the budget, the first step in the process is the call for budget submissions from line ministries, accompanied by the provision of budget instructions including advice about indicative spending levels. Once these submissions are received, the MoF needs to analyze these submissions prior to holding hearings with staff from these ministries to refine the submissions.

The Ministry of Finance analysis will first need to check for factual accuracy and consistency, for example, whether the staffing level is consistent with the approved level and whether this level can be funded from the requested resources. ${ }^{1}$ The next level of analysis should assess the likely effectiveness and efficiency of the expenditure. This focuses on the balance between the expenditure categories, in particular the salaries/operations and maintenance (O\&M) mix, and the likely sustainability of the project (in particular, is there overcapitalization?).

The third level of analysis takes a perspective of the government as a whole and focuses on areas of potential duplication or unexploited synergies. It also looks at the overall balance between different sectors 
within the government, ensuring that the overall balance of expenditure is supportive of the government's broader goals including sustainable economic growth with a focus on poverty reduction. At this stage, the Ministry of Finance is also required to provide advice on policy issues with major implications for public finances (for example, public sector pay issues).

Following the officials-level meetings, the MoF prepares the appropriations legislation that provides the legal spending authority to the ministries, and supporting budget material for the finance minister to present to the cabinet or ministerial council. Based on the deliberations of the cabinet, the appropriations legislation may need to be modified. Once the cabinet has agreed, the legislation is presented to the legislature.

During the preparation process, the Ministry of Finance will have to liaise extensively with international financial institutions to ensure that the budget will receive the support of these institutions. This endorsement is a key element in ensuring direct support from donors for the expenditure program included. Extensive liaison will also be required with the donor governments to refine their proposed expenditures and attempt to direct their expenditures to priority areas. This work will almost entirely be undertaken by the budget department in the MoF.

\section{Execution}

\section{Raising revenues}

During the budget year, it is the responsibility of the tax and customs administrations to ensure that all internal resources that the state is legally entitled to mobilize are raised to meet the spending needs.

In the case of taxation administration, annually there are four key elements. The first is registration and accounting for payments from taxpayers. Most governments adopt systems of self-assessment for taxes where the taxpayer is assumed to be willing to voluntarily comply with obligations. A high-integrity tax identification number acts as a core component for the identification of taxpayers and the monitoring of their payment obligations. The second is annual assessments and reconciliation of amounts due. Collection enforcement for outstanding amounts can follow. The third element is education and taxpayer awareness. The administration must ensure that taxpayers understand their self-assessment obligations and how to make payments according to law. Programs of taxpayer rulings may bind the administration to a view of the law for complex transactions and so provide more certainty to taxpayers. The final element is enforcement. Administrations adopt a risk-management approach so that the highest priority risks to compliance are acted upon and in a manner that acts as a point of leverage to future compliance. 
Hence, a focus on large taxpayers and an active program of audits, desk reviews, and court-based prosecutions are common elements.

The key element of a customs administration is collecting revenue; this involves the administration of a number of duties and levies, including customs duties, excise duties, and levies for other ministries. In this area, customs agencies are concerned with increasing the efficiency of the collection process in order to reduce the ratio of collection cost to revenue. The work involves the areas of tariff schedules, valuation, exemptions, warehousing, import/export procedures, controls of import quotas, dealing with incorrect descriptions, and examinations.

Customs may also have responsibilities to protect the revenue base through antismuggling and fraud control. In many countries customs authorities also have responsibility for protecting society from the import and export of prohibited or restricted items and for facilitating trade.

Ensuring that external resources are mobilized is also a challenge. This includes ensuring that both loan agreements and grant agreements are effectively negotiated and signed, and then the funds disbursed into the government's accounts. This work may be best undertaken by an external relations unit in the ministry, possibly in consultation with the legal department of the ministry.

\section{Managing expenditures}

Ensuring that expenditure takes place in accordance with the legally approved appropriation is traditionally the responsibility of the treasury within the Ministry of Finance. This involves the preparation of monthly or quarterly allotments for budgetary units or subbudgetary units and processing the claims for expenditures. When expenditures are legitimate, checks are issued for cashing at the Central Bank. Generally some sort of automated financial management system supports this process. In a mature system of public expenditure, funds are generally all sourced from a single treasury account. A complication in the case of a country like Afghanistan is the multitude of possible funding sources from which funds can be provided, including special grant accounts and special loan accounts. This means that an additional task is ensuring that cash from special accounts, such as multilateral trust funds that operate on a reimbursement basis, must always be aggressively pursued.

To ensure the smooth operation of the treasury financial management system, the treasury will also need to issue guidance notes and instructions to the line ministries to ensure that they can easily comply with the requirements. Ongoing training and mentoring of the line ministry staff will also be needed.

The Ministry of Finance needs the capacity to oversee administrative units of the central government throughout the country, as no autonomous subnational government can be held accountable separately 
for fiscal matters. This means that branch offices of the treasury (mustoufiats) are essential. The unitary nature of the system is not, in principle, any more complicated than other arrangements. However, in practice, given the infrastructure and security situation in Afghanistan, the considerable challenges of central control and coordination that require additional dedicated resources are available to the treasury.

A major complication in managing expenditure comes when the resources to meet the monthly or quarterly allotted expenditure are not available. Since Afghanistan has a commitment to no overdraft financing, if the resources are not present in the account, cash rationing must take place. The consequences of this are very damaging for operational efficiency and so managing the cash flow is a key task for the treasury. This includes providing advice to the minister or deputy minister on the cash situation and options to manage a shortfall.

A final task that the treasury must undertake is to manage the routine adjustment of budget allotments in accordance with the budget framework legislation, or any subordinate legislation or regulations. For example, it is common to allow a ministry to reallocate some funds within their overall budget between expenditure categories to meet emerging needs. The treasury manages this process.

The core task of treasury is executing the budget-including managing the cash flow. However a range of expenditure-management issues are not inherently part of core treasury business, but are often located within the treasury for organizational convenience. Two particular tasks are the management of the stock of debt and the preparation of an asset register. The management of the stock of debt includes ensuring that the debt service and repayment schedule is prepared and executed, and providing advice to the minister on the overall level of debt, including any sustainability issues.

\section{Managing Policy Change}

The Ministry of Finance (MoF) must ensure that the risks around the successful execution of the budget are managed. This involves proactively managing other parts of the government and ensuring that the financial impacts of different policy issues are understood. The output for most of this work is advice to the minister that can then be used in cabinet debates. These risks are of three sorts: failures in other organizations, policy proposals that directly reduce revenue or increase expenditure, and actions that reduce economic growth and therefore reduce revenue.

The MoF is completely reliant on a functioning Central Bank and functioning finance departments in each of the line ministries to execute the budget. Without the Central Bank providing information on the 
expenditure and revenues that are processed, reconciliation of accounts and auditing is not possible. Similarly, if the line ministry does not provide timely and accurate information, the budget cannot be executed. If either of these areas is not performing, the ministry needs either to work at the official's level to solve the problems, or prepare material so that the minister can deal bilaterally with either the Central Bank governor or ministerial colleagues, to address them,

Many proposals that come forward during the course of a fiscal year have financial impacts that are either not known, not understood, or not quantified-and often all three. The sponsoring minister will rarely be concerned with the overall fiscal impact of the proposal-focusing far more on the narrow impact in the affected area. Common among these are international or national agreements that give either fiscal concessions or public assets to different entities. As the MoF is responsible for the overall management of the revenue system, it is key that the ministry provides advice on the impact of these decisions for the overall fiscal system, so that the cabinet can make an informed decision. In a more mature system there will be some structural protections for the fiscal balance, for example, the requirement that the financial impact of the proposal must be agreed to by the MoF before the proposal is considered by the cabinet. This safeguard does not reduce the work that the ministry must do; it simply ensures that it happens.

As discussed above, economic growth is a key driver for overall revenue growth. That is, as the economy grows, so too do the major tax bases, such as income tax, consumption tax, and customs. This means that if policies are enacted that lead to a lowering of the overall level of economic growth, then the level of revenue will also be reduced. Many policies that are proposed are designed to support a specific sector or project. While they may assist this sector, often it is at the expense of the broader economyso the specific sector is helped, but overall the impact on growth is negative. Other policy proposals are designed to meet social goals. However, in many cases these goals are met at the expense of economic growth. For example, minimum wage laws will provide social protection to those who retain their jobs, but may reduce the overall level of employment, with associated reductions in the level of economic activity and hence the revenue collected. In this context, the Ministry of Finance must become the advocate for overall economic growth as this ensures that the revenue needed to fund the expenditure plan can be collected.

\section{Monitoring and Reporting}

Over the course of the year, the MoF needs to monitor and report on the government's fiscal position. This includes the preparation of monthly (or 
more frequent) reports of expenditure and revenue, which include actual collections and expenditures matched against estimates. These monthly reports will form the basis of the cash management analysis that will be used in determining whether any cash rationing is needed.

The MoF is also required to prepare the government's annual financial statements. The detail and nature of these reports will often be specified in legislation as will the target audience (for instance, the parliament or the public). The treasury usually performs both of these tasks.

While the treasury is responsible for reporting on the actual spending, in many cases there is also a need to report on the effectiveness of that spending. The question to be asked is, "Did the public funds spent on a program deliver the outcomes that were proposed by the line ministry when requesting the funding?" This assessment of the effectiveness of the spending is a key component in ensuring accountability and is also a critical input into the following year's budget process. If a ministry has spent money but there are no outcomes to show for the expenditure, there is an argument to reduce the expenditure in the future. Reporting on the effectiveness of expenditure is often the responsibility of the budget department owing to the synergies with preparing the budget, including future budgets.

A specific monitoring challenge arises when a considerable portion of assistance is provided either in-kind or in grant agreements that are not managed through the treasury. Both of these forms of assistance are less than ideal, as they require parallel systems of administration. It is essential that the government has the capacity to monitor the expenditure on government-endorsed projects, even when that expenditure is not handled through the treasury. This ensures that these projects deliver value for the public, as the government is held accountable for this expenditure even though it doesn't control it. It is also critical to ensure overall cohesion in the expenditure policy and that the government knows what is being done. The management and monitoring of grant expenditure is best done by an external relations unit.

\section{From Theory to Practice}

\section{The Overall Architecture of the Ministry}

Undertaking the core business discussed above involves arranging the tasks according to areas of obvious synergies. The location for many of these tasks has been touched upon above, but to summarize, the MoF must contain four key departments: customs administration, tax administration, treasury, and budget. An economic unit may or may not be part of the budget department. The functions of these units need support from 
administrative departments in the ministry. The key tasks of these basic units within the ministry are as follows:

\section{CUSTOMS ADMINISTRATION}

- Administer the customs system, including running customs houses outside Kabul.

- Provide reports to treasury on customs revenue collected.

TAXATION ADMINISTRATION

- Administer the taxation system, including running the provincial tax offices.

- Provide reports to treasury on taxation revenue collected.

\section{TREASURY}

- Manage execution of budget including operation of Financial Management Information System and management of provincial financial offices (mustoufiats).

- Provide advice on cash management.

- Undertake debt-management and asset-management functions.

- Prepare monthly and annual financial statements.

\section{BUdGet DEPARTMENT}

- Prepare budget materials for the cabinet and prepare final budget including appropriations legislation.

- Provide advice and analysis on policies around major drivers of expenditure, for example, staffing numbers or pay policy.

- Provide advice and analysis on monthly financial trends and on effectiveness and efficiency of expenditure.

- Through an external relations unit, ensure that donor resources are mobilized, including ensuring that appropriate legal agreements are signed for grants and loans.

\section{ECONOMIC UNIT}

- Prepare revenue estimates, based on macroeconomic estimates, and prepare policy options for increasing revenue collection.

- Provide ongoing advice on policy issues that will either directly or indirectly impact on the revenue collected by the government, including treaties or other similar legal agreements. 
To ensure that the core business of the ministry is carried out effectively, the internal administration of the ministry will also need to be running smoothly. The administration department will need to focus on the following priorities.

Information technology —all business areas above will rely heavily on information technology (IT) to deliver their products effectively. The IT area will need to ensure that IT solutions are delivered to these areas in a seamless manner and that the ministry has an IT system that meets its needs. Presently the computing system has developed in an ad hoc manner linked in with other ministries. Computer support needs upgrading. An urgent priority is the development of a comprehensive computing solution for the ministry, at both central and provincial levels. Part of this will involve a dedicated and secure network. Dedicated technical assistance is needed in this area.

Human resource management- to ensure that the ministry is able to deliver results in a sustainable and cost-efficient fashion an effective human resource (HR) unit will be critical. This unit will have responsibility for overall HR policy including, recruitment, testing, retention, advancement, ongoing training, and career development. A particular HR challenge is to ensure that the staff of the ministry outside of Kabul (which comprise the majority of the ministry staff) are adequately managed from a HR perspective.

Budgeting and accounting - the Ministry of Finance requires its own budgeting and accounting area to ensure that the public funds needed to operate the ministry are available, spent, and accounted for.

General services - the ministry also needs a general services unit that will take care of issues such as building maintenance and management or the ministry car fleet.

Two other units are critical to the operation of the Ministry of Finance. First, with the large number of legal agreements to which the MoF is a signatory, a dedicated legal unit is essential. While the line areas of the ministry can provide comments on the broad policy intent of an agreement, dedicated legal staff are essential to ensure that the drafting of the agreements gives legal effect to that policy intent. In addition, an audit unit is necessary to provide the checks and balances in the expenditure system. By monitoring and selectively auditing programs and procedures the audit unit ensures that the MoF and, more broadly. public expenditure are operated in a more effective and efficient manner.

\section{Allocating the Responsibilities}

The areas of work outlined above fit naturally into a system with three deputy ministers: revenue, finance, and administration, in the structure outlined in figure 5 . 


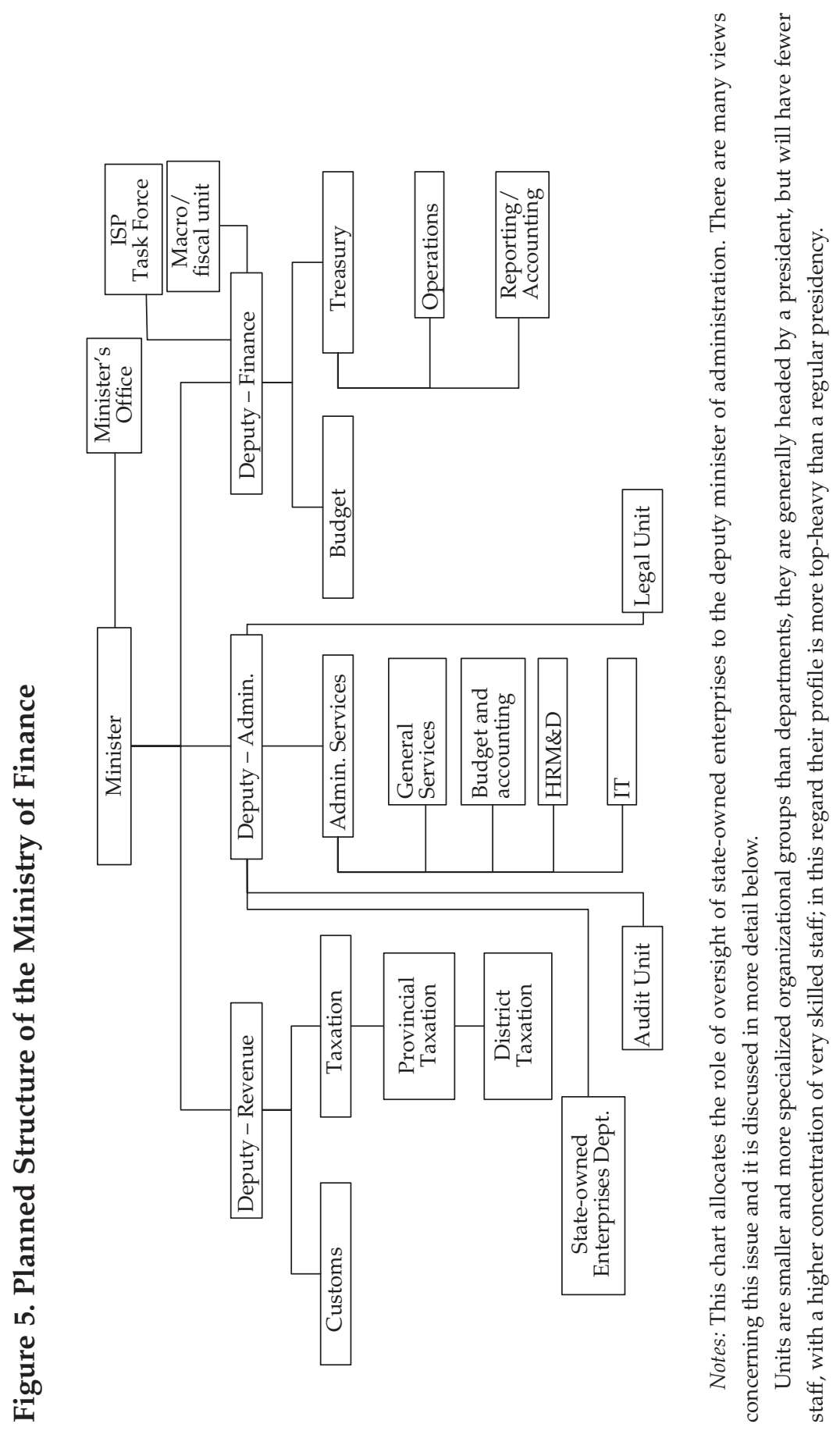


The deputy minister for revenue is responsible for the administration of the revenue system. This includes the administration of the customs system, the large taxpayer unit, and also the provincial tax offices. An unresolved question is where revenue policy should be located. Ideally, revenue policy would be separated from revenue administration. However, with the shortage of available resources, it may be necessary to locate the policy and administration functions under a single deputy minister. Similarly, reporting on revenue outcomes would be the responsibility of the deputy minister for revenue. But the deputy minister for finance would have the responsibility for putting together the overall financial statements. The planned structures of the revenue headquarters and provincial revenue departments are presented in figures 6 and 7, and the planned structure of the customs department is in figure $8 .^{2}$

The deputy minister for finance is responsible for the preparation and execution of the annual expenditure plan. Under the deputy minister would be the treasury, the budget department, and the economic unit. Noting the criticality of using the budget to coordinate the efforts of external development partners, external relations would be undertaken through a dedicated development budget and external relations unit within the budget department (not included in the organization chart).

The budget department should also be the institutional home for authorizing the tashkeels that set the establishment levels of all ministries and provincial departments and districts. These have become disconnected from the takhsis (the budgetary allotment). Historically, the tashkeels were prepared in a presidency within the Ministry of Finance, and their preparation was regarded, very correctly, as one element of preparing the overall budget. During the early 1990s this responsibility was moved out of the MoF and the tashkeels are now agreed to by joint committees of the respective line ministry and the Office of Administrative Affairs (OAA) in the President's Office, under the oversight of the vice president and head of the Civil Service Commission. This process provides the OAA with authority to agree to tashkeels without the prior agreement of MoF as to the budgetary commitment that they represent. Discussion is in progress within the administration to address this disconnect.

The proposed organizational structures for the treasury and the budget departments are shown in figures 9 and $10 .^{3}$

The deputy minister for administration is responsible for the overall administration of the ministry. Within this deputy minister's area would be a department of administrative services, comprised of four units: HR, IT, finance and budgeting, and general services. The deputy minister would also be served by two stand-alone units: legal and audit. The structure for the department of administrative services is shown in figure 11. 


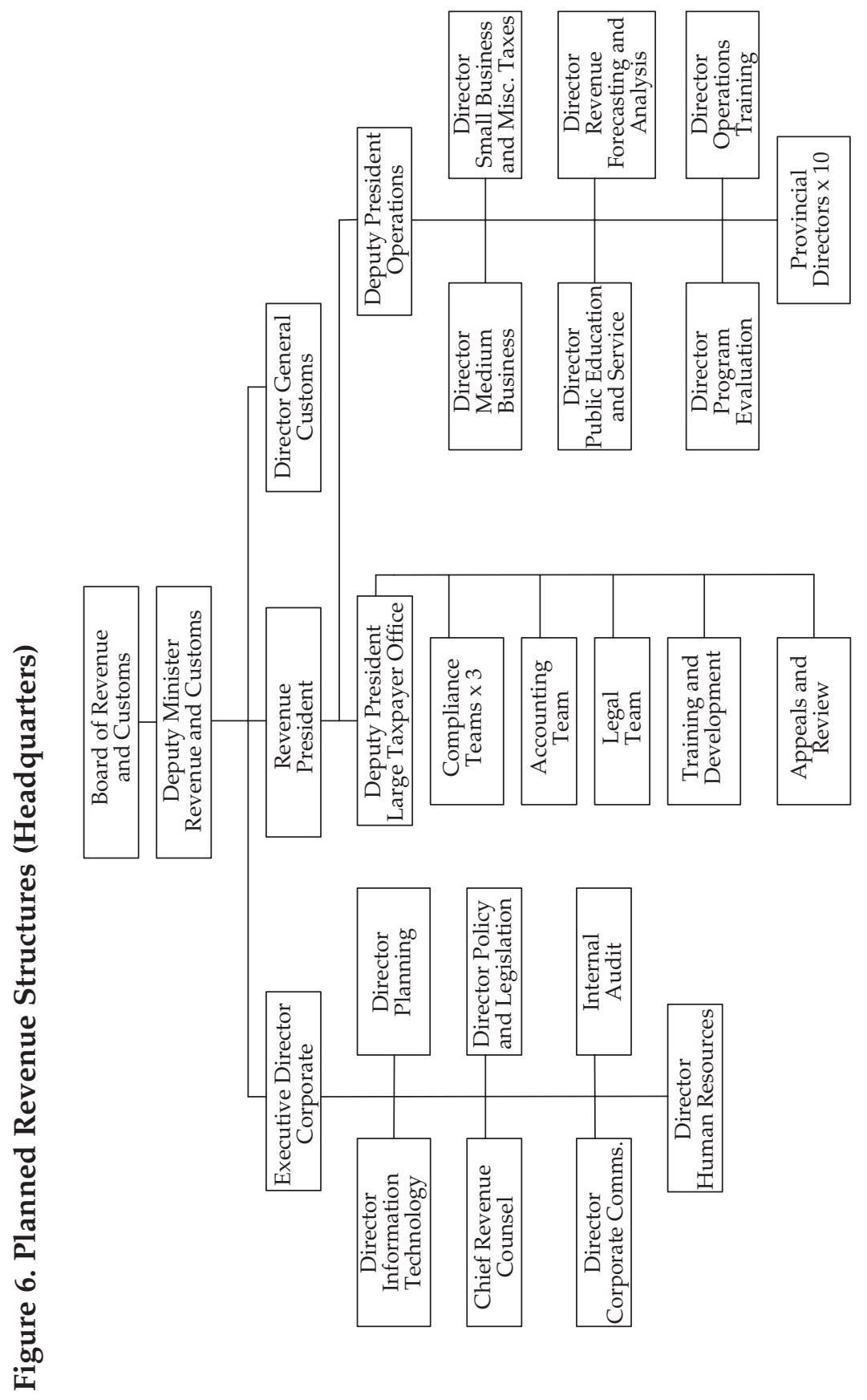




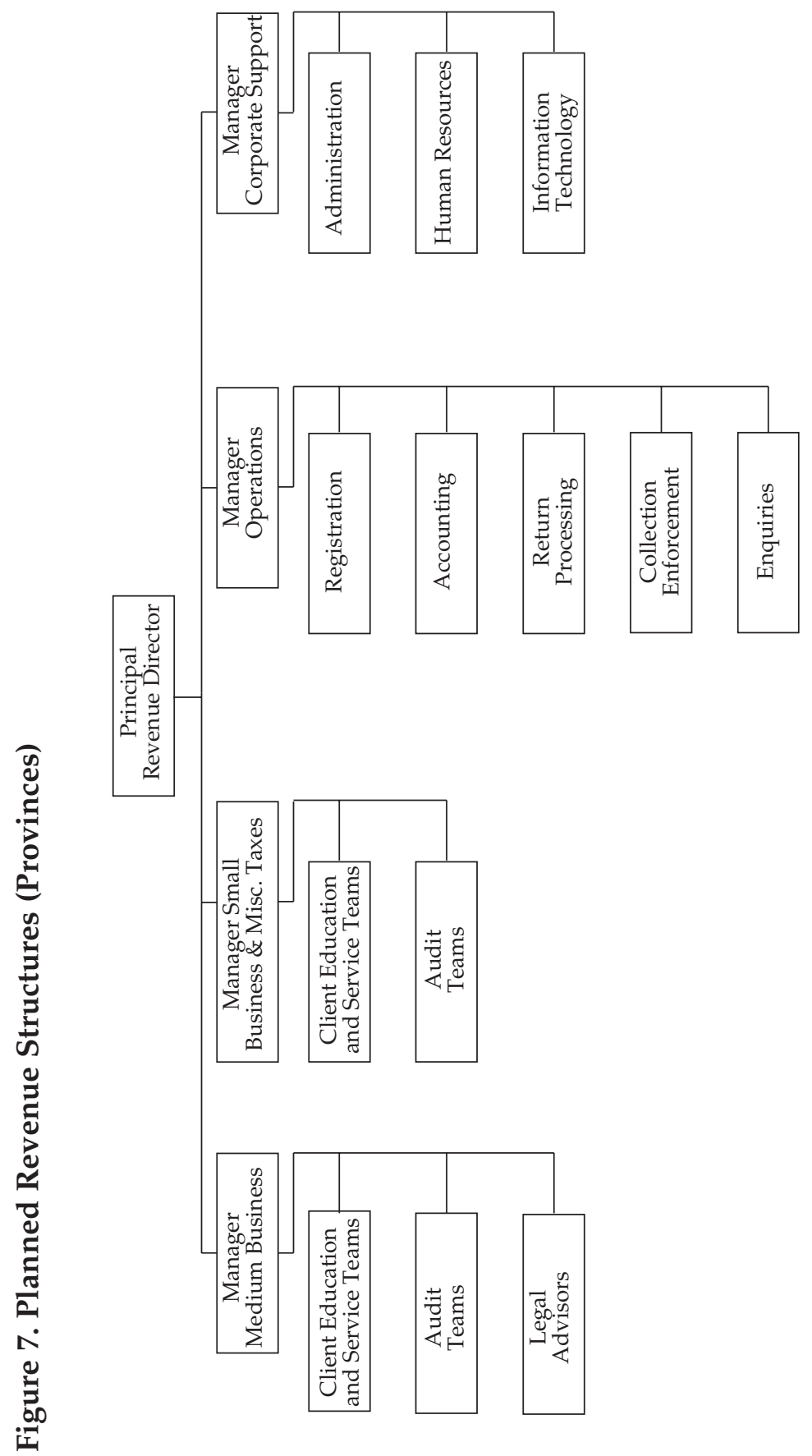




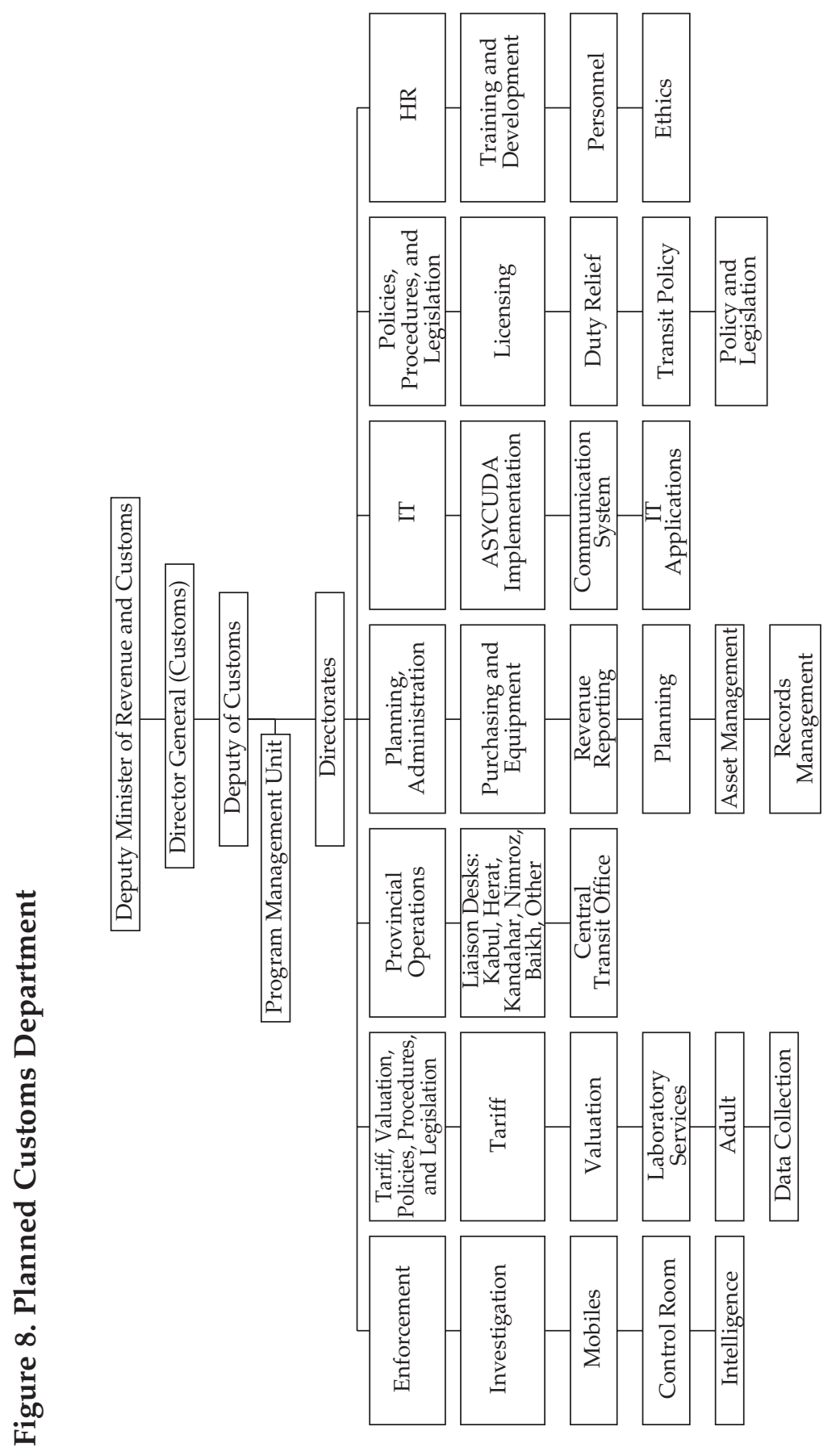




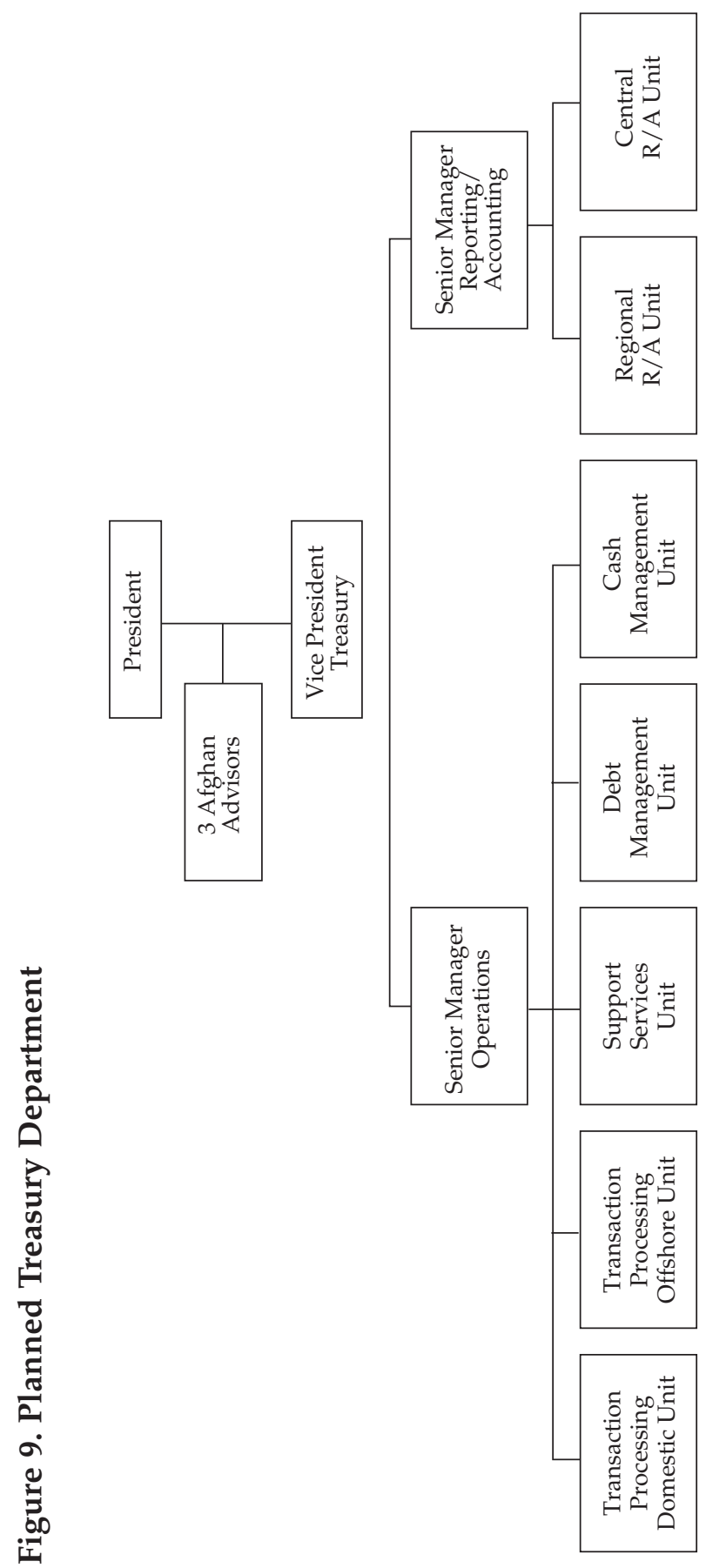




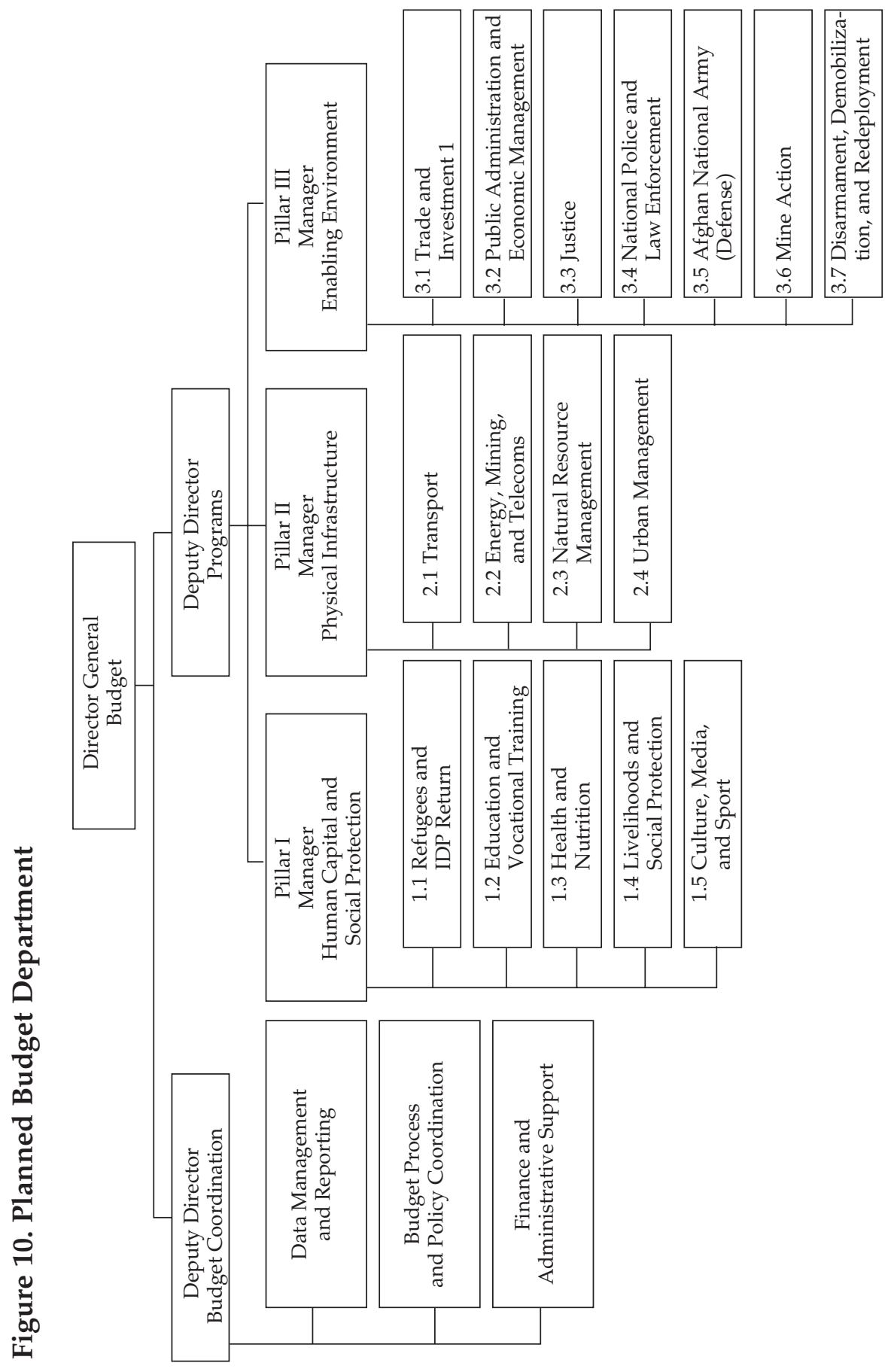




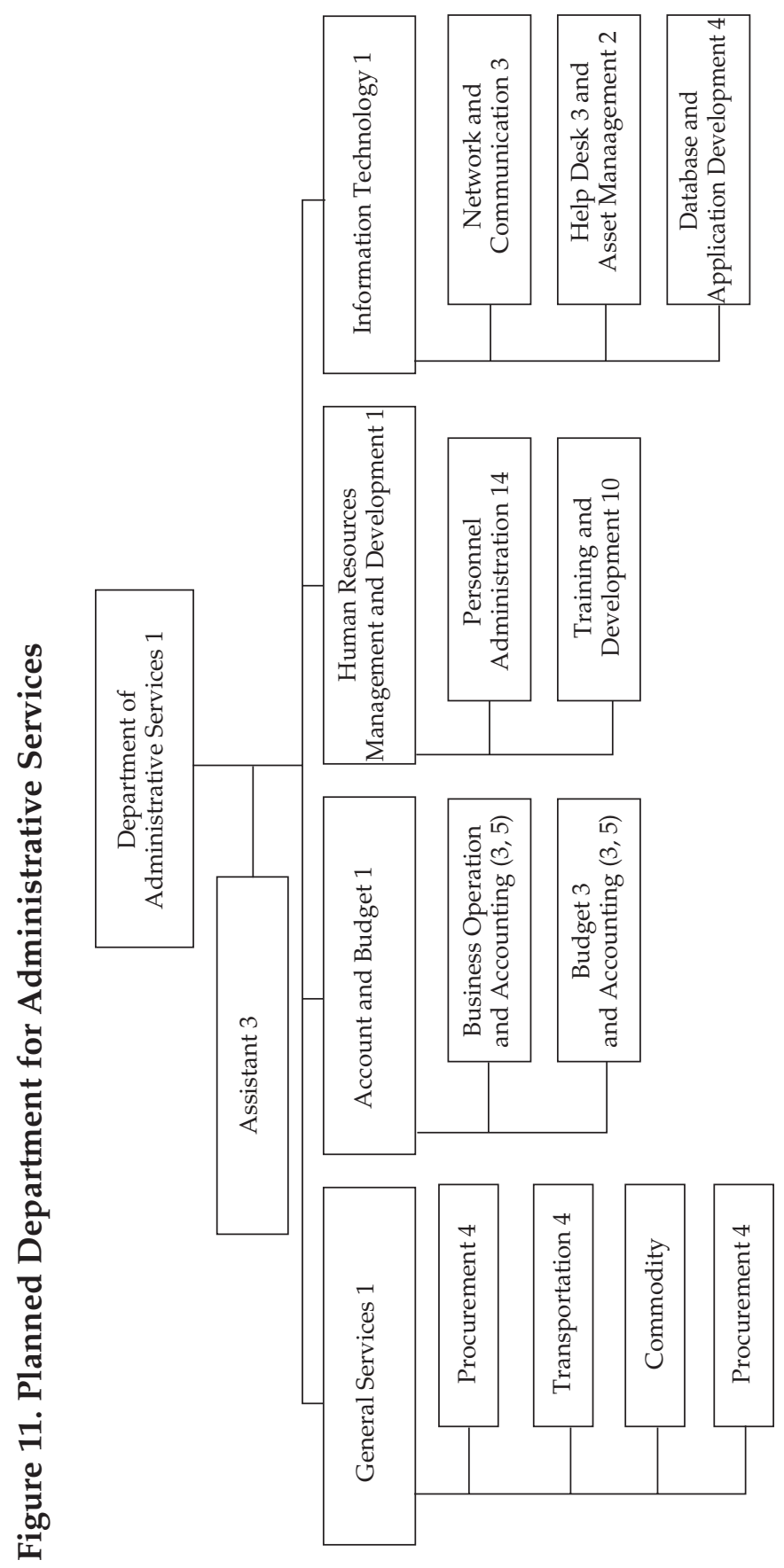




\section{Structuring for Other Tasks}

The two major additional tasks that the Ministry of Finance needs to do in Afghanistan during a transitional period are to provide oversight of the state enterprises and take responsibility for individualizing the salary payments system. These are not part of the ministry's core business, but are critically important tasks that will not be performed adequately unless located here.

Afghanistan has been left with a legacy from the Soviet occupation, and even earlier, of over 150 state-owned enterprises ranging from completely nonoperational factories (albeit with large holdings of scarce land) to those that are fully operational with significant revenues and expenditures. In aggregate, these enterprises have significant assets and revenue streams. They also have liabilities, and the risk is major that the assets could be stripped in a nontransparent manner that does not maximize the value accruing to the state.

In Afghanistan, the Ministry of Finance has traditionally had responsibilities for oversight of these enterprises, including approving any capital injections or operating subsidies, and is a majority shareholder in many of the most valuable enterprises. Over time there will need to be a process undertaken to reform these enterprises, including asset sales, privatizations, corporatizations, and restructuring. Until this takes place, and responsibility for this oversight is strengthened, the MoF will need to retain its oversight role. This responsibility will fall to the deputy minister for administration.

As noted earlier, the payment of salaries to civil servants remains one of the largest areas of corruption and discontent. To address this, the Ministry of Finance has established a task force, reporting to the deputy minister for finance, that is responsible for introducing individualized salary payments as a priority. With the development of a functioning banking system, this will become a much simpler task, requiring few resources. However, in the interim it is a critical task that will occupy considerable time and resources.

\section{Tasks That the Ministry Should Not Undertake}

A number of other tasks have financial implications or could be done in the Ministry of Finance. There are two major reasons for not locating these functions here. First, additional tasks will draw the focus of the minister and senior management away from the core business of the ministry, and will increase the costs of coordination across the ministry. Second, the centralization of all tasks in a single area or ministry may lead to discontent among other parts of the government, which could manifest itself in the undermining of either these additional tasks or of the ministry's core business. 
The two major responsibilities that should not be handled by the Ministry of Finance are overall civil service policy and procurement. (See box 10 on how civil service policy has been handled in other countries.)

While the overall performance of the civil service will have major impacts on the effectiveness of government expenditure, and therefore on the quantity of inputs needed to deliver specific outputs, these issues are

\section{Box 10. Who Is Responsible for Civil Service Policy?}

In essence, the answer is most often a ministry for the public service, rarely the finance ministry, and almost never the Civil Service Commission.

A recent informal survey of World Bank staff with responsibility for major civil service reform programs provided insights into the leadership of 11 reform programs. ${ }^{*}$ It showed that 6 of the 11 programs were led by the equivalent of a ministry for the public service (Brazil, Ecuador, Pakistan, Rwanda, Thailand, and Yemen). Five others were led by a unit specially created in the Prime Minister's office (Albania, Bolivia, Ghana, Honduras, and Latvia).

Any entity leading the effort to create a meritocratic, depoliticized civil service has to be widely perceived to be supported by the head of government. Putting the agency directly under the head of government keeps the reporting line clear and avoids raising issues of whether a minister of public administration is "more equal" than other ministers. It does however raise a subsidiary question, namely, whether the director of the unit, who by definition is not a minister, should be able to impose requirements on ministers.

In only one country, Ghana, the Ministry of Finance currently leads the program. Historically, in Bolivia the Servicio Nacional de Administracion de Personal (SNAP) was a decentralized agency that reported to the Minister of Finance. This agency is in charge of: the designing of human resources regulations, the operation of the human resources information system, and the implementation of training policies and programs. It was intended to be the champion entity to carry out civil service reform, but it was both weak and politicized.

Although 5 of the 11 countries had the equivalent of an arms-length public service commission (Albania, Bolivia, Ghana, Latvia, and Pakistan), the commission was not responsible for leading the program in any of these cases.

* The survey was undertaken in December 2002 by Ranjana Mukherjee, World Bank, and provides insights into the programs in Albania, Bolivia, Brazil, Ecuador, Ghana, Honduras, Latvia, Pakistan, Rwanda, Thailand, and Yemen. 
best handled by a body outside of the Ministry of Finance. Issues such as servicewide recruitment, performance management, promotion, or personnel management are best handled in a dedicated body. The natural location would be a specific civil service body, either located on a standalone basis, as part of the president's office, or as part of a ministry of administrative affairs, should such a ministry be created. The Ministry of Finance should be involved in discussions of civil service pay policy only in its role as providing advice on the sustainability of expenditure and the effectiveness of different expenditure policies to meet government outcomes.

Procurement is another key task for a government. In a mature government, much of the procurement is devolved to the line ministries with only major procurement handled by a separate unit. The policy, including regulations and guidelines that govern procurement, are prepared and monitored in a central procurement office. In the case of a post-conflict country, things are more difficult as there are often a number of major contracts combined with a shortage of trained procurement officers and concerns over the integrity of the procurement process. To address these concerns, creating a dedicated procurement unit to handle both the policy and the operations of the procurement for the government has merit.

\section{Managing Transition}

In public policy, a well-documented difference exists between policy design and institutional reform. The former discusses where you would like to be in an unconstrained world. The latter looks at the steps that can be taken to move you from where you are, closer to where you would like to be. Policy design is a useful tool that allows the decisionmaker to see how far there is to travel, but it is mute on key issues including sequencing or pace of reforms. The remainder of this chapter outlines the key principles that the Ministry of Finance is observing in its institutional renewal program.

In essence, the ministry is observing four fundamental principles:

- Stick to the core business

- Select the right senior staff

- Use technical assistance carefully

- Prioritize physical infrastructure improvements.

The most critical issue in managing transition has been the creation of an environment where officials with honesty and integrity are able to work together to drive through critical reforms. 


\section{Avoiding Overloading Well-Functioning Ministries}

The discussion above outlined the core competencies that the ministry has argued within government and to donors and other international partners. The ministry is determined to avoid embellishments or distractions that risk diluting focus and scarce resources. While many issues are important, it is critical that the Ministry of Finance focuses on its core business. In a post-conflict environment, or an environment with weak institutions, the temptation to allocate important tasks to the ministry or ministries that are operating effectively is always present. However, doing this runs the risk of compromising the delivery of core reforms in these ministries.

\section{Attracting and Selecting Senior Staff}

The challenge of leadership in the Ministry of Finance is, of course, immense. However, the particular leadership that is necessary is one that balances clarity of vision, coupled with a willingness to make pragmatic operational decisions even when the available facts are limited.

Operationally, the decisions made by the Minister of Finance that have had the most significant impact have concerned the appointment of the three deputy ministers. By attracting three strong deputy ministers, and encouraging them to recruit other strong candidates, a process of cultural change can be started from the top and work its way through the ministry.

It is striking that none of the three current deputy ministers has any substantial prior experience in public finance. It is equally striking that this has not been a barrier to achievement. All are of unquestionable integrity and possess strong leadership skills. In addition, each has a strong background in administration and experience in management. Finally, each has the ability to listen to, challenge, and then act on advice from experts, predominantly international experts. These behaviors and characteristics are considerably more valuable than technical experience.

\section{Using Technical Assistance}

During the past 18 months, a considerable amount of technical assistance has been provided to the Ministry of Finance. A number of issues have been raised concerning the volume and quality of technical assistance (TA) provided, particularly over the extent to which the absorptive capacity for advice and reform in the MoF and, more broadly, the government has been exceeded, and the extent to which technical assistance was supply, rather than demand, driven. 
Moving forward in this area, a number of lessons can be learned from these experiences. First, a key lesson in development is that if a project or a concept is not domestically owned, it will not take root and prosper. The same is the case for technical assistance in the Ministry of Finance. When reforms or proposals are not domestically owned, they will not be acted on. A key role for any technical assistance is to be sure that a market for the product exists before too much investment is made in developing the product.

The second issue is simple to outline but considerably more complex to solve. International providers of technical assistance are paid dramatically more than their national counterparts, generating understandable resentment and tensions within the ministry. In many cases, they also report outside the line management structure, making them difficult to control or to hold accountable for their work. ${ }^{4}$

The problems of resentment are exacerbated by the fact that most international staff providing technical assistance in the Ministry of Finance have support staff working for them either as translators or for data entry or general office support. These staff are also paid considerably more than the counterparts of the international staff. Anecdotal evidence suggests that the wages paid to the assistants of international staff outstrip the wages paid to senior civil servants well after a country moves out of the post-conflict limelight!

Allowing the Ministry of Finance to raise wages unilaterally on the basis that it is undertaking priority tasks could in principle solve the pay disparities. However, the problem in this approach is that the disparities between the salaries payable on an international labor market, and those payable on any skilled local labor market, are enormous. Creating a scale that includes grades that could attract international experts would generate enormous inflationary risks within the public sector, as there would be many arguments that domestic staff should also receive these higher salaries.

The pay issue is being partly ameliorated by the intensive use of the Priority Reform and Restructuring (PRR) Decree. The treasury, revenue, budget, and customs departments have all received stage 2 approval for enhanced salaries under the PRR Decree. ${ }^{5}$ Although this does not take local staff to levels that are remotely comparable with international staff, it does significantly reduce the wage disparity between civil servants and national consultants.

The issue of accountability is being resolved by requiring that all contract staff funded through technical assistance have a single employer-and in particular cannot make an "end run" around managerial decisions by appealing to their funding body. This effectively places such TA-funded consultants into two groups. 
The first group comprises those whose funding body is prepared to ensure that the staff operate to all intents and purposes as if they were in line positions. This means that the consultants can be removed or have their work program redirected by their line manager with no appeal to the funding body. To assist in creating the right incentives, these consultants should have very little prospect of further employment from the funding agency (and ideally none) if their performance is unsatisfactory. For consultants in this group, the traditional caveat against TA-funded consultants acting in line positions no longer applies.

The second group comprises TA-funded consultants where the ministry is not confident that they can be directed (and effectively disciplined) by their line manager. For these staff, their work is treated by the ministry as useful suggestions from external agencies, but cannot be regarded as core to the ministry's business as the ministry does not have control over the consultants. It is important that these consultants are not liable to regularization without further recruitment procedures, as they have been appointed on the basis of criteria laid down by their funding agency and not by government.

Serving civil servants should consider the rates of pay for these consultants to be clearly exceptional and not providing any benchmarks or comparators. Thus for staff of both groups, it is important that their claim to international rates of pay is credible and that they can demonstrate they are indeed marketable within an international or at least regional labor market.

Ultimately, all such approaches are less than perfect, and there is an overarching approach to ensure that clear transition plans are in place. This transition has three stages. While early TA funded international staff to undertake in-line capacity substitution, more recent TA funding is training a cadre of what will effectively become national consultants. These national consultants, funded by the same resources that fund the international consultants, then operate with limited international oversight for a further period of possibly two to three years. During this period, as they are consultants, they can be funded at significantly higher wages than can be paid, even by a reforming civil service. However, these national consultants have the duty to train the national civil service staff. These national staff will then be able to take on the positions in subsequent years at an attractive wage level, following the reforming of the civil service.

In this model, international consultants do the bulk of the work for the first year or two, while training the national consultants. For the following two or three years, the national consultants do the bulk of the work, while training the new cadre of civil servants. Then the civil servants take over line responsibility, with a small number of national consultants (and 
an even smaller number of international consultants) retained in advisory positions.

\section{Focusing on Physical Infrastructure}

Overall, the experience of donor support to the Ministry of Finance in Afghanistan has been too much advice and too little support for the basic office infrastructure. Almost two years after the Transitional Administration, the central office of the Ministry of Finance does not have reliable electricity or a reliable Internet connection. Over $\$ 10$ million has been spent providing international technical assistance to the Ministry of Finance, but that technical assistance cannot be guaranteed to have an office with electricity.

\section{Creating an Enabling Environment}

One of the major challenges facing a government in a post-conflict environment is to attract talented people into the civil service. While low wages are often quoted as a barrier to attracting staff, this is perhaps the easiest hurdle to overcome. A far greater challenge is that many of the most talented people do not feel that they can be effective in a bureaucracy that is accused of high levels of corruption and nepotism, or with the perceived constraints from working under the current cabinet. These people with a commitment to public service consider that they can create far more value for society by staying out of the government and working in the nongovernment sector or through international agencies. In these positions, they are able to work in traditional civil-service-type roles, including service delivery and coordination and advocacy.

Perhaps the most significant contribution of the current finance minister has been the creation of a safe and politically neutral space within which officials with honesty and integrity can operate and thrive. Through the creation of this enclave, a growing number of officials have been attracted to the ministry, safe in the knowledge that professional work will lead directly to policy reforms and actions and that assessment and advancement will be on the basis of merit. Moreover, these officials work with the satisfaction of knowing that their work will be presented to the cabinet for endorsement. They also work secure in the knowledge that political interference in the workings of the Ministry of Finance is not tolerated.

This contribution is not as visible as the passage of a new customs code or reforms, such as a treasury single account. However, it has been absolutely fundamental to the transition of the Ministry of Finance. Without this, staff of the right caliber to form the reform team simply would not have materialized, and without this team the transition would not be occurring. 


\section{Notes}

1. To ensure consistency between the approved staffing levels and the budget, it is essential that the responsibility for establishment control is also located in the budget department of the Ministry of Finance. The MoF does not currently have the authority to control the primary budget unit (PBU) or secondary budget unit (SBU) tashkeels; and the tashkeelat (the unit in the Office of Administrative Affairs that approves the tashkeels) is now involved in the budget process but not formally a part of the budget department, still leaving some room for inconsistency. For 1383, it is anticipated that the tashkeels and takhsis should be broadly consistent-and ministries are invited to report specific problems within four weeks of the start of 1383.

2. The use of the term "board" implies an interministerial body, but does not necessarily imply any significant degree of administrative autonomy.

3. Subsequent to the preparation of this chapter the senior management of the Ministry of Finance decided to locate the accounting section under the Deputy Minister (Administration) rather than the Deputy Minister (Finance). While there was agreement that the long-term location of the accounting unit should be under the Deputy Minister (Finance) it was considered that given the current allocation of responsibilities among the Deputy Ministers and Presidents of Departments and the need to build a modern accounting function from scratch, the section would be more effectively established outside of the Treasury and its longer-term location determined subsequently.

4. The only arrangement that has come close to avoiding these fundamental problems is essentially a system of noblesse oblige, where diaspora returnees volunteer their services at no cost.

5. Under the PRR Decree, stage 1 approval calls for documented evidence of the need for reform (and of the minister's personal commitment to it), and of the establishment of a suitably skilled task force to lead and manage the reform and restructuring process. Stage 2 requires a more detailed proposal, specifying the expected improvements in efficiency and cost-effectiveness, and documented evidence that the relevant function has been comprehensively reviewed with the aim of shedding unnecessary tasks and simplifying systems and procedures. In addition, ministries must identify and justify the posts recommended to be placed on the PRR pay scale, and provide a full costing of the proposed changes. 


\section{References}

The word processed describes informally reproduced works that may not be commonly available through libraries.

Evans, Anne, Nick Manning, Yasin Osmani, Anne Tully, and Andrew Wilder. 2004a. A Guide to Government in Afghanistan. Kabul: AREU and the World Bank.

Evans, Anne, Nick Manning, Anne Tully, Yasin Osmani, and Andrew Wilder. 2004b. Subnational Administration in Afghanistan: Assessment and Recommendations for Action. Kabul: AREU and the World Bank.

Fölscher, Alta. 2002. "Budget Transparency and Participation: Five African Case Studies." Africa Budget Project. Cape Town: Idasa: Budget Information Service.

Holmes, Malcolm, and Nick Manning. 2003. "Observations on a Structure for a Ministry of Finance." Washington, D.C.: World Bank (processed).

Inter-Parliamentary Union. 1986. Parliaments of the World. A Comparative Reference Compendium, 2nd edition. Aldershot, U.K.: Gower.

"Mid Term Budget Review." 2003. Kabul: Transitional Islamic State of Afghanistan.

Ministries of Planning Reconstruction and Finance. 2002. "Working DraftPlan and Budget for 1381-82 National Development Programme." Kabul.

"OECD Best Practices for Budget Transparency." 2001. Paris: OECD. Found on the Internet at $h t t p: / / w w w . o e c d . o r g / d a t a o e c d / 33 / 13 / 1905258 . p d f$.

Schiavo-Campo, Salvatore, and Daniel Tommasi. 1999. Managing Government Expenditure. Manila, Philippines: Asian Development Bank. Found on the Internet at http://www.adb.org/Documents/ Manuals/Govt_Expenditure/default.asp\#contents.

"Securing Afghanistan's Future: Accomplishments and the Strategic Path Forward." 2004. Kabul: Transitional Islamic State of Afghanistan and international agencies. Found on the Internet at http://www.af/ recosting/index.html.

Wehner, J. 2002. "Parliament and the Power of the Purse: The Nigerian Constitution of 1999 in Comparative Perspective." Journal of African Law 46(2): 216-31. 


\section{Index}

Note: $n(n n)$ refers to endnote(s).

accountability, 146-147

Ministries of Finance, 72, 77-80

models, 77-80

accounting, 133

accounts, settling, 36

administrations, subnational types, 108

administrative services department, 141

deputy minister, 135

afghani, 4

Afghanistan Assistance

Coordination Authority

(AACA), 21-22

aid management, Ministries of Finance, 75

allocation process, 49

allotments, 18-19, 30nn.7, 8, 43

establishing, 35

procedures for 1383, 46

provincial, 31, 32-34

salary expenditures, $39-40$

amendment powers, 85-87

appropriations, 18-19

assistance

basic immediate for municipali-

ties, $120-122$

covert, 4-5

see also technical assistance

audit, 22-23, 88-89, 98-99 bank accounts, 9

block grants, 121-122

board, $149 n .2$

budget

amendment, 95-97

cycle, 125

defined, 95

department, 132, 135, 140

development, 23-29, 64n.4

execution, 37, 58, 97-98

literacy, parliament, 90

modification, $87-88$

municipalities, 116, 118-119

ordinary, 12-20, 30n.4, 64n.4

parliament, 89

policy implications, 43,47

preparation, 89, 95-97, 116, 118-119

presentation, 83-84

provincial, $31-47$

recurrent, 58-59

reporting, 98

salaries, 39-40, 47n.1

shortfalls, 4

support, 49

Taliban, 4-5

budget 1380, 5

budget 1381, 7, 13-14, 23

challenges, 13

defense, 15

passage, 14 
budget 1382, 7, 15-17, 25, 29n.2

passage, 17

preparation, 15

review, 17

budget $1383,25,30 n .8$

allotment procedures, 46

budget 1384, 93n.8

budgeting, 133

budget execution, 69-70

budget preparation, 69

continuous, 87

East Timor, 50-59

Eritrea, 59-62

Ministries of Finance, 69-71, 73

post-conflict, 48-64

Uganda, 62-64

budget law, weaknesses, 100-101

budget system, legal and institutional framework, 103

budget system law

budget execution, 97-98

budget preparation and amendment, 95-97

budget reporting, 98

control and audit, 98-99

current, 100-101

municipal administrations and, 99

objectives, 94-95, 100

reform, 94-106

state-owned enterprises and, 100

budget system law, new, 101-106

enforcement, 102, 106

implementation, 106

legal framework, 101-103

buildings, municipal, reconstruction funds, 121

capacity building, budget, 16

centralization of tasks, 142 civil service policy, 143-144

classification, 95

coalition government, 5-6

conflict, fiscal management and, 4-6

constitution (2004) , 82-89

amendment powers, $85-87$

bicameral parliament, $82-83$

budget modification, $87-88$

budget presentation, $83-84$

executive reporting and audits, 88-89

legislation with budgetary implications, 88

timing, 84-85

control, 98-99

core business

consensus, 124-131

execution, 127-129

covert financing, nonaccountable, 4

currency, 4

depreciation, 4

customs, 128

administration, 132, 138

collection process, 8

houses, 6

rates, $9-10$

decisionmaking authority, 8-9

defense force, 13

budget, 15

deficit financing, 4

development budget, 23-29,

$64 n .4$

challenges, 27-29

executing, 26-27

management, 24-25

preparation, 23

donor assistance database (DAD), 28

donors, 27, 30n.9

setting targets, $57-58$ 
East Timor, post-conflict budgeting, 50-59 2001-02 budget, 55-57

budget evolution, 51-53

budget review, 53-54

expectations, 59

lessons learned, 57-59

economic unit, 132-133

enabling environment, 26, 148

Eritrea, post-conflict budgeting, 59-62

Ministry of Finance leadership, 61-62

technical assistance, 60-61

exchange rate, 14

executive reporting, 88-89

expenditure controls, municipalities, 119

Expenditure Review Committee (ERC), 96

expenditures

allotments, 32-33

managing, 128-129

non-salary, 34-38

off-budget, 13

preparing program, $126-127$

fiduciary risk, sources, and means of reducing, 119

finance

constitution, 81-93, 92n.3

covert, 4

deficit, 4

deputy minister, 135

intergovernmental, 70-71

policy, monitoring and report-

ing, 130-131

sector regulation, Ministries of

Finance, 74

financial management, $6-7$

law, 104-105

system, 20-21

forms, 8 general services, 133

government, 4

levels, 6

revenue management,

Ministries of Finance, 74

gross flow approach, 6

human capital and social protection, 26

human resource management, 133 see also staff

importers, 11

information

access, 90-91

technology, 133

infrastructure, physical, 148

institutional reform, 144

internal audit, Ministries of

Finance, 76

international consultants, 146,

$149 n .4$

accountability, 147

international development, 12

Karzai, Hamid, 5

Large Taxpayer Office, 9

legislation

budgetary implications, 88

budget law, new, 101-106

budget law reform, 94-101

budget system law, current, 100-101

legislature

budget amendment powers, 86

powers, 85

loya jirga, 5

Meshrano Jirga, 82

mindsets, changing, Kabul municipality, 118

ministries, overloading, 145 
Ministry of Finance, 67, 80n.1 advisory role, 77 aid management, 75 budgeting, 69-71, 73 civil service policy, 143-144 Eritrea, post-conflict budgeting, 61-62

financial sector regulation, 74 functions, 68-76 government revenue management, 74 internal audit, 76 key elements, 131-133 macro-fiscal policy, 68-69, 73 national economy, 76 non-core functions, 71-72 personnel management, 75 procurement, 75, 144 reforming, 123-150 responsibilities, 73-76 responsibility allocation, 133 , 142

revenue and policy administration, 71

state-owned enterprises, 72,76 structure, 134, 149n.3 task not to be undertaken, 142-144 treasury functions, 74 municipalities, provincial, 107-122

administration by province, 115 block grants, 121-122

budget, 99, 106n.1, 111-112 capacity and focus, 107-108 central/local relationships, 117 development responsibilities, 109 diversity, 114-116 expenditures, 112, 116, 117-119 fiscal autonomy, 110-111, $122 n .3$ institutional structures, 109-114 organizational restructuring, Kabul, 118 planning, 111-112 population, 108 public sector, larger, and, 108-109 revenues, 111 role, 114-119, 120-122 rural, 114,117 staffing, 112-113 voting and participation, 114 mustoufiat, 9, 33

National Development Framework, 26-27

national economy, Ministries of Finance, 76

needs-based approach, 57 net flow approach, 6 non-salary expenditures, 33-38 traditional process for executing, 35-36

ordinary budget, 12-20, 64n.4 execution, 18-20 preparation, 13-17, 30n.4

parliament

bicameral, 82-83, 93n.5

budget literacy, 90

budget preparation, 89

information access, 90-91

parliamentary committees, 91 role, 89-91

timing, 84-85

payroll, 19-20

centralization, 41

challenges, 40-42, 44-45

districts, 41,42

processing, 22

PEFM law. See Public

Expenditure and Financial Management Law 
pension reform, 120-121

performance measures, 59

periodicity, 95

personnel management, Ministries of Finance, 75

physical infrastructure and natural resources, 26

police force, 13

policy

administration, 71

change, 129-130

design, 144

macro-fiscal, 68-69, 73

revenue, $9-11$

presidential system, $81-82,92 n .4$

priorities list, unfunded, 58

Priority Reform and Restructuring (PRR) Decree, 146, 149n.5

procurement, 21-22, 144

Ministries of Finance, 75

policy unit, 22

project list, prioritized, 40

project ownership, 146

provinces

government, 6

see also municipalities, provincial

Public Expenditure and Financial

Management Law (PEFM

law), 87-88, 91, 94, 102

public expenditure law, structure, 104-105

public finance framework, 92

purchase

authorizing, 35-36

executing, 36

reform

priorities in post-conflict

finance ministries, $67-80$

Uganda, post-conflict budget-

ing, 63

resource-based approach, 57 resources, estimating, 124, 126

revenue

administration, 8-9

challenges, 11-12

deputy minister, 135

-generating capacity, estimations, 58

headquarters, 136

incentives, 119

Ministries of Finance, 71

policy, 9-11

progress, 7-12

provincial, 137

raising, 127-128

reform, 8-9

reporting and forecasting, 12

revenue collection, $7-8$

illegal, 7

provincial, 8

rural municipalities, 114

central/local relationships, 117

salaries. See wages

sector program list, 49

shopping list, project, 40

Single Administrative Document, 8

skill development, Kabul municipality, 118

staffing, 14, 149n.1

attracting and selecting, 145

see also wages

state-owned enterprises, 72, 76, 142

budget and, 100

sustainability, long-term fiscal, 57

takhsis, 39, 40

tariff, 10, 29n.3

tashkeel, 32, 39, 40

taxation, 11, 12, 127-128

administration, 132

tax paying, 9 
technical assistance, 120

Eritrea, post-conflict budgeting, 60-61

Uganda, post-conflict budgeting, 63-64

using, 145-148

see also assistance

transition, managing, 144-148

translation, 11

transparency, 95

Treasury, 132

account, 12

department, 139

functions, Ministry of Finance, 74

role, 129

treasury single account (TSA), 98
Uganda, post-conflict budgeting, 62-64 reforms, 63 technical assistance, 63-64 United Nations Transitional Authority in East Timor

(UNTAET), 50, 51, 52

unity, 95

universality, 95

wages, 32, 33-34, 142, 146, 147 provincial budget allotments, 39-40

payment delays, 21

payments, 22

reform, 120-121

Wolesi Jirga, 82, 83 

Ministers of Finance in post-conflict countries face unique challenges. At a turbulent time when both financial and human resources are limited, what should a finance ministry do- -and, more importantly, not do? Which countries offer successful examples of reform that can be used as models for finance ministry reform in other countries?

Reforming Fiscal and Economic Management in Afghanistan sets out the impressive policy and institutional reforms made by the interim and transitional administrations of Afghanistan since the Bonn conference in November 2001. It explores the complexities of managing the significant amount of development assistance and donor interest while balancing the need to respond to donor priorities and to build strong publicsector institutions. The book demonstrates that the budget must be the primary vehicle for developing and then implementing policy, and shows how this strategy has shaped the renewal of Afghanistan's finance ministry. The volume closes with a specific agenda for finance ministry reform and restructuring.

Although this edited volume is focused on Afghanistan, the questions raised have broad relevance for other countries seeking to restart economic and fiscal management following conflict. Reforming Fiscal and Economic Management in Afghanistan will be of great interest to finance ministries, national governments, international and nongovernmental organizations, and research institutions — and to anyone interested in post-conflict reconstruction and reform.

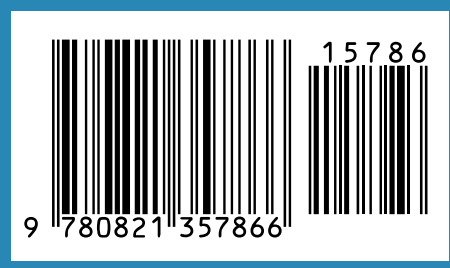

ISBN 0-8213-5786-7 